UNIVERSIDADE DE SÃO PAULO

FACULDADE DE ECONOMIA, ADMINISTRAÇÃO E CONTABILIDADE DE RIBEIRÃO PRETO

DEPARTAMENTO DE CONTABILIDADE

PROGRAMA DE PÓS-GRADUAÇÃO EM CONTROLADORIA E CONTABILIDADE

Decisões de financiamento em empresas brasileiras: uma comparação entre a static tradeoff e a pecking order theory no Brasil

PAULO FERREIRA AMARAL

Orientador: Prof. Dr. Fabiano Guasti Lima

RIBEIRÃO PRETO

2011 
Reitor da Universidade de São Paulo Prof. Dr. João Grandino Rodas

Diretor da Faculdade de Economia, Administração e Contabilidade de Ribeirão Preto Prof. Dr. Sigismundo Bialoskorski Neto

Chefe do Departamento de Contabilidade de Ribeirão Preto Profa. Dra. Adriana Maria Procópio de Oliveira

Coordenador do Programa de Pós-Graduação em Ciências Contábeis e Controladoria de Ribeirão Preto

Prof. Dr. André Carlos Busanelli de Aquino 
PAULO FERREIRA AMARAL

\section{Decisões de financiamento em empresas brasileiras: uma comparação entre a static tradeoff e a pecking order theory no Brasil}

Dissertação apresentada à Faculdade de Economia, Administração e Contabilidade de Ribeirão Preto da Universidade de São Paulo como requisito para obtenção do título de Mestre em Ciências no Programa de Pós-Graduação em Controladoria e Contabilidade.

Orientador: Prof. Dr. Fabiano Guasti Lima 
Amaral, Paulo F

Decisões de financiamento em empresas brasileiras: uma comparação entre a static tradeoff e a pecking order theory no Brasil. Ribeirão Preto, 2011.

95 p. : il. : $30 \mathrm{~cm}$

Dissertação de mestrado apresentada à Faculdade de Economia, Administração e Contabilidade de Ribeirão Preto/USP. Área de concentração: Controladoria e Contabilidade.

Orientador: Lima, Fabiano Guasti.

1. Financiamentos. 2. Estrutura de Capital. 3. Modelos Financeiros. 4. BM\&FBOVESPA 


\section{FOLHA DE APROVAÇÃO}

Paulo Ferreira Amaral

Decisões de Financiamento em Empresas Brasileiras: Uma Comparação Entre a Static Tradeoff e a Pecking Order Theory no Brasil.

Dissertação apresentada à Faculdade de Economia, Administração e Contabilidade de Ribeirão Preto da Universidade de São Paulo como requisito para obtenção do título de Mestre em Ciências no Programa de Controladoria e Contabilidade.

Área de Concentração: Controladoria e Contabilidade

Aprovado em:

Banca Examinadora

Prof. Dr.

Instituição: Assinatura:

Prof. Dr.

Instituição: Assinatura:

Prof. Dr.

Instituição: Assinatura: 
Dedico este trabalho:

À minha esposa, Maria Adelaide (in memoriam), com muito amor, por ter me incentivado a continuar estudando, mesmo durante a pior fase de sua doença. Aos meus filhos, Arthur, Alex e Paulo. 
Agradecimentos

A Deus, por ter me dado forças para voltar a estudar, mesmo em época um tanto tardia de minha vida.

Agradeço ao meu orientador, Prof. Dr. Fabiano Guasti Lima, que tendo aceitado o encargo um tanto tardiamente, conseguiu, com sua paciência e boa vontade, corrigindo, incentivando, sugerindo melhorias, fazer com que este trabalho chegasse a um bom termo.

Agradeço a todos os professores da graduação e do mestrado da FEARP, especialmente à Prof. Dra. Maísa, ao Prof. Dr. Evandro Saidel, à Prof. Dra. Adriana, ao Prof. Dr. Carlos Godoy, ao Prof. Dr. Assaf Neto, ao Prof. Dr. Eliseu Martins, ao Prof. Dr. Sílvio pelo grande incentivo que me deram nos momentos mais difíceis.

Agradeço, mais uma vez, a minha esposa (in memoriam), por todo o incentivo que me deu para terminar este mestrado.

Aos funcionários da FEA-RP, especialmente à Érika, que sempre me atenderam com toda a atenção e dedicação. 


\section{RESUMO}

\section{Amaral, Paulo F. Decisões de Financiamento em Empresas Brasileiras: Uma} Comparação Entre a Static Tradeoff e a Pecking Order Theory no Brasil. Dissertação (Mestrado) - Faculdade de Econonia Administração e Contabilidade de Ribeirão preto - USP, Ribeirão Preto, 2011.

A comparação entre duas teorias na área de finanças sobre estrutura de capital nas empresas é o objetivo deste trabalho. Usando testes desenvolvidos por Shyam-Sunder \& Myers (1999) e Rajan \& Zingales (1995), os dados de empresas brasileiras, não financeiras, de capital aberto foram analisados entre os anos de 2000 e 2010 para verificar se preferiram os comportamentos previstos na Static Trade-off Theory ou os da Pecking Order Theory. As maneiras de se financiar e as causas e conseqüências dessas decisões nas empresas são importantes questões que vêm sendo debatidas em inúmeros trabalhos acadêmicos. Este trabalho procurou analisar a bibliografia relacionada ao tema e replicar testes realizados no exterior, visando verificar as semelhanças, diferenças e os motivos relacionados a tais resultados. Os resultados obtidos apontam para a provável preferência do comportamento previsto pela Pecking Order Theory, isto é, as empresas estudadas, no período analisado, usaram, em primeiro lugar, recursos gerados internamente (caixa operacional), usando em segundo lugar recursos de terceiros, por meio de empréstimos bancários ou emissão de debêntures, somente emitindo ações como última alternativa. Outra conclusão foi que as empresas brasileiras de capital aberto provavelmente não procuram alcançar ou manter uma meta ideal de endividamento, que equilibre os custos e benefícios gerados pelos empréstimos.

Palavras-Chave: Estrutura de Capital, Static Trade-off Theory, Pecking Order Theory, Decisões Financeiras, Fontes de Financiamento. 


\begin{abstract}
Amaral, Paulo F. Financial decisions in Brazilian companies: a comparison between the static tradeoff and pecking order theory in Brazil. Dissertação (Mestrado) - Faculdade de Econonia Administração e Contabilidade de Ribeirão preto - USP, Ribeirão Preto, 2011.
\end{abstract}

The comparison between two theories in the finance area of capital structure in business is the goal of this work. Using tests developed by Shyam-Sunder \& Myers (1999) and Rajan \& Zingales (1995), the data of Brazilian non-financial publicly traded were analyzed between the years 2000 and 2010 to determine whether they preferred the expected behaviors in the Static Trade-off Theory or the Pecking Order Theory. The ways to finance and the causes and consequences of these decisions in organizations are important issues that have been discussed in numerous scholarly works. This study sought to examine the literature related to the theme and replicating tests performed abroad in order to verify the similarities, differences and the reasons related to such results. The results indicate the problabe preference behavior provided by Pecking Order Theory, ie the companies studied in the period analyzed, used, first, internally generated funds (operating cash), second using third-party funds through bank loans or issuance of bonds or issuance of bonds, sending shares only as a last resort. Another conclusion is that Brazilian companies traded problaby did not seek to achieve or maintain an ideal goal of indebtedness, wich balances the costs and benefits generated by the loans.

Key words: Capital Structure, Static Trade-off Theory, Pecking Order Theory, Financial Decisions, Financing Sources. 


\section{LISTAS DE ABREVIATURAS E SIGLAS}

BM\&FBOVESPA - Bolsa de Valores do Estado de São Paulo

CAPM - Modelo que calcula custo do capital de uma empresa (baseado no risco).

$\mathrm{Cg}$ - Variação de Capital de Giro num determinado período

D - Endividamento total / Capital Próprio (alavancagem)

Def - Déficit de uma empresa num período

Div - Dividendos pagos por uma empresa num período

Dj - Total de Empréstimos da Empresa j

DOAR - Demonstração de Origem e Aplicação dos Recursos

E - Variação de Empréstimos num período

Fc - Fluxo de Caixa

i - Taxa de Retorno de Determinado Capital

Inv - Investimentos fixos de uma empresa num período

LCR - Lucratividade de uma empresa

LS - Logaritmo natural das vendas de uma empresa

M \& M - Modigliani \& Miller

MBV - Valor de Mercado / Valor contábil

NPV - Valor Presente Líquido

Pf - Total de financiamento de LP que vence no período

Pk - Taxa de Retorno Esperada de Ativos de Risco k.

PL - Patrimônio Líquido

POT - Pecking Order Theory

$\mathrm{r}$ - Taxa de Juros

R quadrado ajustado - Coeficiente de Determinação

$\mathrm{Sj}$ - Capital Proprio da Empresa j.

STT - Static Trade-off Theory

T - Total de Ativos Tangíveis

WACC - Custo total do Capital usado por uma Empresa 


\section{ÍNDICE DE FÓRMULAS}

Fórmula 1: Fórmula de Modigliani \& Miller (1958) proposição $2 \ldots \ldots \ldots \ldots$

Fórmula 2: Fórmula de Shyam-Sander \& Myers (1999) Déficit do período. . . . . . . . . 45

Fórmula 3: Regressão Dívida x Déficit período Shyam-Sander \& Myers (1999) . . . . . . .45

Fórmula 4: Cálculo do déficit conforme Frank \& Goyal (2002) . . . . . . . . . . . . . 45

Fórmula 5: Cálculo do déficit do período usada nesta dissertação . . . . . . . . . 65

Fórmula 6: Regressão usada originalmente por Rajan \& Zingales (1995) . . . . . . . . . 65 


\section{LISTA DE TABELAS}

Tabela 1: Descrição das variáveis a serem testadas em cada modelo $\ldots \ldots \ldots \ldots \ldots .46$

Tabela 2: Regressão dos fatores $x$ endividamento $(\mathrm{STT}) \ldots \ldots \ldots \ldots \ldots \ldots \ldots \ldots \ldots \ldots \ldots \ldots$

Tabela 3: Sinais esperados e encontrados para as teorias POT e STT . . . . . . . . .60

Tabela 4: Endividamento de empresas brasileiras de capital aberto $(\%) \ldots \ldots \ldots \ldots \ldots 6$

Tabela 5: Regressão Def x Dívidas $($ POT $) \ldots \ldots \ldots \ldots \ldots \ldots \ldots \ldots \ldots \ldots \ldots \ldots \ldots \ldots \ldots \ldots \ldots$

Tabela 6: Uso de fontes de financiamento epelas empresas estudadas . . . . . . . . . . . 70 


\section{LISTA DE FIGURAS}

Gráfico 1 - Endividamento das empresas estudadas / PL . . . . . . . . . . . 63

Gráfico 2 - Dívidas + Debêntures / Capital Total . . . . . . . . . . . . . . . 64

Gráfico 3 - Fontes de financiamento utilizadas pelas empresas estudadas $\ldots \ldots \ldots \ldots 71$ 


\section{SUMÁRIO}

1. INTRODUÇÃ

1.1 Justificativa

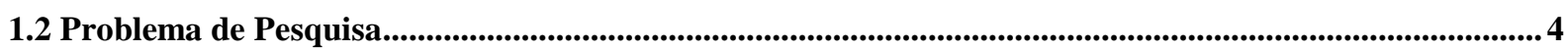

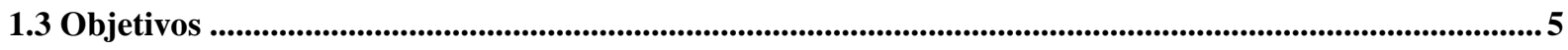

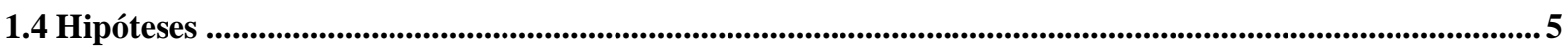

1.5 Estrutura do Trabalho ....................................................................................................................................................... 6

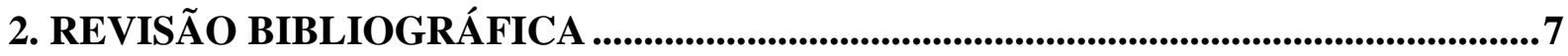

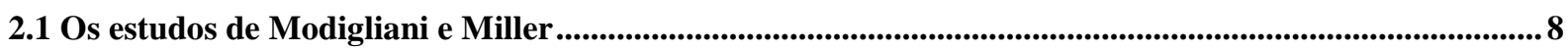

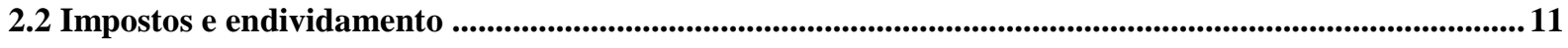

2.3 Custos de falência

2.4 Custos de agência....................................................................................................................................................16

2.5 Fatores que influenciam a estrutura de capital..................................................................................................... 19

2.5.1 Comportamento dos fatores de acordo com a POT................................................................................24

2.5.2 Comportamento dos fatores de acordo com a STT .....................................................................................25

2.6 O que pensam os dirigentes de empresas ...........................................................................................................26

2.7 A procura por uma estrutura ótima de capital.......................................................................................2 27

2.8 Informações assimétricas e a hierarquia das fontes de financiamento ...........................................................31

2.9 Pecking Order Theory X Static Trade-off Theory …………................................................................................34

2.10 Resultados de pesquisas anteriores sobre comparação entre POT E STT ................................................39

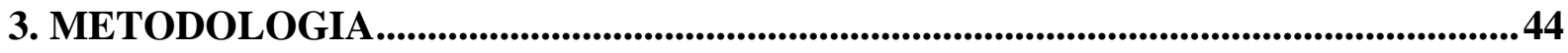

3.1 Metodologia de teste para a POT .................................................................................................................... 46

3.2 Metodologia de teste para a STT..................................................................................................................50

4. RESULTADOS DA PESQUISA ....................................................................................54

4.1 Análise dos Resultados da Regressão dos Fatores x Endividamento (STT) ...............................................54

4.1.1 Estatística teste e pressupostos da regressão da STT ........................................................................................59

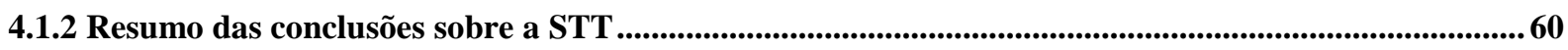

4.2 Análise dos Resultados da Regressão Déficit x Dívida (POT) ……………………….......................................65 
4.2.1 Estatística teste e pressupostos da regressão da POT 69

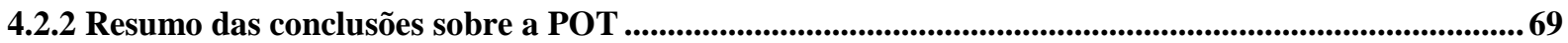

4.3 Tentativa de Interpretação dos Resultados da Pesquisa ................................................................................. 71

5. CONCLUSÃO E SUGESTÕES PARA NOVAS PESQUISAS.......................................74

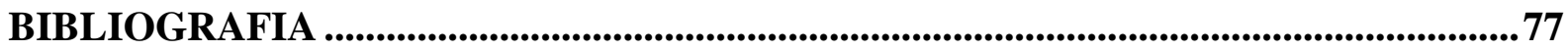




\section{INTRODUÇÃO}

Como uma empresa deve se financiar para obter as maiores vantagens, seja para seus proprietários ou mesmo em benefício da sociedade em que atua? Essa é uma pergunta que permanece sem uma resposta inequívoca, mesmo após intenso trabalho de pesquisa que tem sido realizado em vários países, há muitos anos. Qual o capital traz mais vantagens para a empresa, o próprio ou o de terceiros? A empresa deveria pagar o mínimo possível de dividendos para se financiar com a retenção de lucros? As pesquisas têm dado diversas respostas a essas questões, mas ainda não há nenhuma teoria completa que explique como e porque as empresas tomam suas decisões financeiras, ou como deveriam agir para aumentar seu valor e utilidade.

A partir da publicação do primeiro trabalho de Modigliani e Miller (1958), houve uma mudança na maneira de se analisar a estrutura de capital. Esses autores afirmaram que não importa a proporção de capital próprio e de terceiros que compõe a estrutura para a determinação do valor de mercado de uma empresa. Em 1963, os autores publicaram uma correção em seu trabalho, considerando todos os efeitos que o não pagamento de impostos sobre as despesas com juros acarretariam para as finanças das empresas. No trabalho anterior eles já tinham levado em conta os impostos na formulação de suas hipóteses, mas não todos os efeitos destes sobre o valor da empresa. Nessa nova perspectiva, passaria a haver vantagens no endividamento. Mesmo com essa alteração, não houve mais unanimidade sobre as vantagens da alavancagem, principalmente se excessiva, e o tema passou a ser um dos mais importantes no estudo das finanças corporativas.

Conforme mostrado na parte de revisão bibliográfica deste trabalho, desenvolveu-se toda uma crítica em torno dos dois artigos de M \& M. Sobre o primeiro artigo de 1958, muitos autores, como Durand (1959) e Solomon (1963), não aceitaram as proposições que indicavam não haver relação do valor da empresa com a sua composição de capital. Quanto ao segundo artigo, publicado em 1963, as principais críticas tratavam do problema do excesso de endividamento, que não era previsto pelas novas proposições. Seguindo rigorosamente as hipóteses do artigo de M \& M (1963), as firmas poderiam se endividar infinitamente e assim aumentar seu valor, sem nenhuma conseqüência negativa.

\footnotetext{
* A partir deste ponto, será usada a nomenclatura abreviada M \& M para referenciar os trabalhos de Modigliani e Miller.
} 
Os próprios M \& M (1963, p. 442) procuraram justificar porque as empresas não se endividam, nem mesmo deveriam tentar se endividar, ao máximo possível. Eles se referem às limitações impostas pelos próprios emprestadores e outras existentes no quotidiano, não totalmente investigadas na época. Há também, citada pelos autores, a importância que a empresa dá a sua flexibilidade, mantendo uma reserva de capacidade de endividamento.

Mas a hipótese predominante continuou a ser a de que haveria um grau adequado de alavancagem financeira em relação ao capital próprio que seria o mais adequado para a empresa. A maioria dos trabalhos acadêmicos busca descobrir esse nível de endividamento que maximize o valor da empresa. Se há, quais fatores determinam esse nível. Uma das principais teorias que tentam verificar se as empresas equilibram suas estruturas de capital em torno de um ponto ideal de endividamento para maximizar o valor de mercado é a chamada "Static Tradeoff Theory" (STT).

Por outro lado, há pesquisas que não buscam um ponto ideal de endividamento, são as que verificam outro tipo de teoria. Uma das principais é a "Pecking Order Theory" (POT). Ela é baseada na prioridade de fontes que uma entidade econômica busca para se financiar. As empresas utilizariam em primeiro lugar recursos gerados operacionalmente, só buscariam emitir dívidas se faltasse dinheiro para investimentos e só recorreriam ao mercado de ações em último caso e muito raramente.

A hipótese de indiferença da estrutura de capital para o valor da empresa não foi totalmente descartada após a publicação do segundo artigo de M \& M (1963). Conforme será explicado na revisão bibliográfica desta dissertação, o próprio Miller (1977) mostrou que, quando se leva em conta os impostos pessoais de investidores e emprestadores, as vantagens da alavancagem são menores ou, dependendo do caso, até inexistentes. A Pecking Order Theory (POT) também é indiferente ao valor da empresa sobre diferentes estruturas de capital, apesar de não mostrar isso claramente e tão somente tratar das fontes preferidas de financiamento.

Mesmo após inúmeros estudos teóricos e empíricos sobre as duas teorias, o que fica claro é que ainda não há uma certeza sobre qual delas deveria ser adotada e qual descartada, ou ainda, se elas poderiam coexistir, com modificações, para explicar melhor o comportamento financeiro das empresas. Dessa forma, justifica-se a continuidade das pesquisas relativas ao tema. 
O questionamento para esta pesquisa é: qual a teoria explica melhor o endividamento das empresas? No caso das empresas brasileiras não financeiras e de capital aberto, há um padrão que se adeque às teorias em pauta? E esse comportamento financeiro é o mesmo detectado em pesquisas realizadas no exterior?

Procurou-se, então, verificar os padrões de comportamento de empresas brasileiras de capital aberto, investigando se há adequação a alguma das duas teorias: STT e POT. Para atingir tal objetivo, foram replicados, com adaptações, parte dos trabalhos de Shyam-Sunder \& Myers (1999) com as modificações de Frank \& Goyal (2002) e o teste criado por Rajan \& Zingales (1995). Esses modelos já foram utilizados separadamente no Brasil por Medeiros e Daher (2008).

Na pesquisa original de Shyam-Sunder \& Myers (1999), para testar a POT, os autores usam duas equações (mostradas no capítulo sobre metodologia deste trabalho) que tentam verificar como as empresas se financiam. No teste aplicado originalmente por Rajan \& Zingales (1995) uma regressão entre a variável dependente "endividamento" e as variáveis independentes tangibilidade, lucratividade, tamanho e capacidade de crescimento verifica algumas hipóteses da STT.

Os autores Frank \& Goyal (2002) fizeram uma adaptação no modelo de ShyamSunder \& Myers (1999) que será explicada na metodologia. Medeiros e Daher (2008) foram os primeiros a usar esses modelos no Brasil. Nesta dissertação esses testes foram aplicados em períodos e populações diferentes das dos autores citados, com adaptações que também serão explicadas na metodologia.

Esses testes procuraram verificar se há algum dos dois comportamentos previstos pelas teorias estudadas. No caso da STT, verificar se os fatores se comportam conforme o previsto na teoria. No caso da POT, o procedimento é verificar se os possíveis déficits, após a utilização do caixa operacional para pagamento de dividendos, aplicação em novos investimentos, pagamento de empréstimos e variação do capital de giro, são financiados quase que integralmente com dívidas.

A seguir, apresenta-se a justificativa para a elaboração deste trabalho.

\subsection{Justificativa}

Um estudo sobre decisões de financiamento e conseqüente formação da estrutura de capital, entre tantos outros da mesma espécie, é mais uma contribuição para o conhecimento do funcionamento das empresas brasileiras e do funcionamento de nossos mercados de capital 
e financeiro. Mesmo considerando-se que muitos estudos parecidos têm sido publicados, no Brasil ainda há muito campo para novas pesquisas, inclusive, como é o caso desta, reproduzindo e adaptando estudos internacionais sobre o assunto.

A replicação da pesquisa sobre a Pecking Order Theory, aplicada originalmente por Shyam-Sunder \& Myers (1999), modificada por Frank \& Goyal (2002) e reproduzida no Brasil por Medeiros e Daher (2004), é importante porque é aplicada a dados de períodos e empresas diferentes, servindo para verificar se o comportamento já detectado pelos autores citados se mantém ou não. Há também uma modificação na forma de cálculo do déficit financeiro de cada período, que será explicado no capítulo três (metodologia), trazendo um ponto de vista contábil para o assunto.

A outra pesquisa replicada, que é a de Rajan \& Zingales (1995), também contribui para corroborar ou não a Static Tradeoff Theory em períodos e empresas diferentes das dos autores originais e de Medeiros e Daher (2004), que também a reproduziram no Brasil.

Esta pesquisa também procura mostrar por meio de tabelas e gráficos como as empresas se financiaram durante os anos estudados. Em primeiro lugar, as fontes de recursos, se gerados internamente, de terceiros ou próprios. Em segundo lugar, a média de endividamento, em relação ao capital próprio, ao capital total e aos ativos, verificando se há uma tendência à estabilidade nos níveis de alavancagem financeira.

\subsection{Problema de Pesquisa}

A principal motivação para a pesquisa é tentar entender como as empresas brasileiras de capital aberto se financiam. Nesse caminho surge a questão de pesquisa: As empresas brasileiras, não financeiras, de capital aberto tentam manter um percentual de dívidas em relação ao capital próprio que equilibre os custos e benefícios dos empréstimos, ou preferem usar as fontes mais acessíveis e menos onerosas, sem manter uma meta fixa para o total de empréstimos?

No caso de prioridade no uso de fontes de financiamento menos onerosas, quais as fontes que são usadas preferencialmente e quais as menos usadas. Esses modos de se financiar são os mesmos das empresas estrangeiras? Ou há algumas peculiaridades próprias que refletem características brasileiras?

$\mathrm{Na}$ área de finanças, importantes pesquisas sobre financiamento de empresas estão sendo amplamente debatidas, com resultados muitas vezes ainda contraditórios. A simples 
repetição cuidadosa de experimentos anteriores é necessária para que haja matéria para confirmação ou refutação das teorias.

Para tentar responder ao problema proposto, são comparadas as duas das teorias mais debatidas nas finanças quando se trata de decisões de financiamento das empresas. A mais aceita delas e que vigora há mais tempo é a Static Trade-off Theory (STT), em que as empresas, dependendo de características próprias e exógenas, escolhem qual o melhor nível de capital de terceiros deve manter em sua estrutura financeira. A outra teoria é a que não aponta para um nível ótimo de alavancagem, mas tenta provar que as empresas se financiam segundo uma hierarquia de fontes, preferindo sempre as menos onerosas. Chamada de Pecking Order Theory (POT), esse modelo defende que as empresas sempre preferirão reter caixa operacional próprio, recorrendo a empréstimos em segundo lugar e só indo ao mercado de capitais como último recurso.

Para completar, os resultados são analisados e comparados com os de trabalhos similares no país e no exterior.

\subsection{Objetivos}

Esta pesquisa tem como objetivo verificar como as empresas brasileiras de capital aberto, exceto as financeiras, se financiam. Em primeiro lugar, se suas decisões de financiamento visam a formar ou a manter estruturas de capitais que lhe sejam mais adequadas (Static Tradeoff Teory). Ou se elas não têm esse tipo de meta e recorrem mais aos fluxos de caixa próprios, usando capital de terceiros em caso de déficit de caixa e só vendendo títulos de propriedade no mercado mobiliário em casos extremos (Pecking Order Teory).

Esse tipo de verificação é importante para observar a adequação de importantes hipóteses das finanças ao comportamento de firmas que atuam no mercado aberto brasileiro. Há também o interesse de saber o porquê de possível predominância de determinado tipo de comportamento.

\subsection{Hipóteses}

Para atingir o objetivo propostos para esta dissertação, foram testadas as duas proposições a seguir: 
I - As empresas brasileiras se financiam principalmente com capitais próprios, isto é, propiciados pelo seu fluxo de caixa operacional. Em caso de necessidade de mais recursos recorrem em segundo lugar a empréstimos e financiamentos de terceiros ou venda de debêntures e títulos assemelhados. Só em último caso essas firmas emitem ações no mercado mobiliário (POT).

II - O modelo de financiamento usado pelas firmas de capital aberto no Brasil é a de manutenção de uma estrutura ótima de capital, se comportando segundo o modelo conhecido como "Static Tradeoff Theory" (POT), buscando para tanto uma meta ideal de empréstimos que equilibre custos e benefícios.

Visando atingir o objetivo proposto e verificar as hipóteses do trabalho, a seguir apresenta-se a estrutura proposta para esta pesquisa.

\subsection{Estrutura do Trabalho}

Esta dissertação está organizada em cinco capítulos, que estão organizados da seguinte maneira. O primeiro capítulo, que é a introdução, inclui os subtítulos: Justificativa, Problema de Pesquisa, Objetivo, Hipóteses e Estrutura do Trabalho.

No capítulo dois, que é a Revisão Bibliográfica, são resumidos e analisados os mais significativos textos pesquisados para a realização desta dissertação. Ele está subdividido em: (i) Revisão Bibliográfica, (ii) Modigliani e Miller - Artigos e Críticas (iii) Impostos e Endividamento, (iv) Custos de Falência, (v) Custos de Agência, (vi) Fatores que Influenciam a Estrutura de Capital, (vii) O Que Pensam os Dirigentes das Empresas (viii) A Procura Por Uma Estrutura Ótima de Capital, (ix) Informações Assimétricas e a Hierarquia das Fontes de Financiamento, (x) Pecking Order X Static Trade-off Theory, e (xi) Resultados de comparação de pesquisas anteriores sobre POT e STT.

No capítulo três a metodologia utilizada na realização do trabalho é explicada. No capítulo quatro, o mais importante do trabalho, os dados colhidos são analisados e os principais resultados são expostos e comparados com os de outras pesquisas. O capítulo cinco traz a conclusão, considerações finais e sugestões para outras pesquisas. 


\section{REVISÃO BIBLIOGRÁFICA}

A finalidade desta revisão da literatura sobre estrutura de capital é verificar como o assunto se desenvolveu nas últimas décadas e qual o atual estado da arte envolvendo os estudos sobre a comparação das teorias conhecidas como Pecking Order Theory (POT) e Static Tradeoff Theory (STT). Para este objetivo serão analisados os textos teóricos e pesquisas empíricas relacionadas ao assunto.

Tendo em vista o número, a variedade e complexidade dos trabalhos publicados em toda a comunidade acadêmica sobre o assunto, esta pesquisa procurou levantar os principais textos relacionados a financiamento e estrutura de capital nas empresas, principalmente os que trabalharam especificamente o tema desta dissertação.

Os principais trabalhos pesquisados foram os de Myers (1984), Myers \& Majluf (1984), e Harris \& Raviv (1991), Rajan e Zingales (1995), Shyam-Sander \& Myers (1999), Fama \& French (2000) e Frank \& Goyal (2002). Não há como ignorar os importantes trabalhos de Modigliani \& Miller (1958 e 1963). No Brasil, considera-se que os artigos importantes relacionados ao assunto estudado são os de Famá e Melher (1999), Famá e Grava (2000), Famá e Barros (2001) e Silva e Brito (2004). No tema específico da comparação das teorias POT x STT, destaca-se o de Medeiros e Daher (2008).

A organização da revisão bibliografia foi elaborada com o intuito atender aos objetivos do tema pesquisado. Para tanto o começo, como tantos outros trabalhos na área, foi com os trabalhos de Modigliani e Miller $(1958,1963)$ e as críticas a respeito. Sem a apresentação das conclusões desses autores os temas referentes a metas de empréstimos para otimizar o valor da empresa (se há ou não essa meta) e que fontes de recursos usar não teriam sentido.

A parte seguinte trata dos possíveis benefícios e custos do endividamento. Impostos, custos de agência e de falência têm relação direta com as teorias estudadas na dissertação. Principalmente, aquelas vantagens relacionadas à não cobrança de imposto de renda sobre os juros dos empréstimos e os custos relacionados ao aumento do risco de falência numa empresa muito endividada. O motivo para o estudo desses benefícios e custos é entender porque uma empresa procuraria ou não um nível ideal de empréstimos.

Como grande parte da pesquisa empírica realizada para este trabalho teve como base alguns fatores que influenciam a estrutura de capital de uma empresa, incluiu-se um subitem sobre esses fatores. Os principais fatores, no que se refere a esse trabalho, são o tamanho da firma, sua expectativa de crescimento, a lucratividade e tangibilidade de seus ativos. 
Os dois itens seguintes são sobre as teorias comparadas na dissertação. Como elas surgiram e se modificaram no tempo, os principais trabalhos relacionados a cada uma delas, os problemas em seu desenvolvimento e o estado atual delas. Por motivos óbvios são partes muito importantes do desenvolvimento da pesquisa bibliográfica.

Finalmente, os últimos itens da revisão tratam da confrontação das duas teorias, dos trabalhos publicados sobre elas e dos resultados empíricos encontrados. São os itens essenciais, que deram um norte à pesquisa empírica realizada.

Uma questão crucial para tomada de decisões nas empresas é a estrutura de capital. Como otimizar a produção de riquezas trazendo benefícios aos investidores e garantindo a continuidade do empreendimento? Como produzir mais e melhor com os menores custos? Essas e outras questões correlatas vêm sendo muito discutidas no meio acadêmico desde meados do século XX.

Antes do artigo de M \& M (1958), havia quase certeza de que a empresa aumentava seu valor com o uso de capital de terceiros, até o ponto em que o risco elevado começava a aumentar o custo total do capital e, conseqüentemente, a diminuir o valor da empresa. Após a publicação do trabalho de $M$ \& M (1958), não houve mais certeza quanto às vantagens do endividamento. Mesmo depois da publicação da correção do artigo original não voltou a haver consenso no estudo das finanças empresariais.

\subsection{Os estudos de Modigliani e Miller}

A proposição I do estudo de M \& M (1958, p. 268), diz que: “...the market value of any firm is independent of its capital structure and is given by capitalizing its expected return at the rate pk appropriate to its class." Isto significa que é o valor presente dos fluxos de caixa esperados, descontados a uma taxa adequada ao seu nível de risco, que forma o valor de mercado de uma empresa, não interessando como ela é financiada. Conforme explicado por Ross et al (2002, p. 322), essa proposição significa que:

...uma empresa não é capaz de alterar o valor total de seus títulos mudando as proporções de sua estrutura de capital. Em outras palavras, o valor da empresa é sempre o mesmo, qualquer que seja a estrutura de capital. Em ainda outras palavras, nenhuma estrutura de capital é melhor ou pior do que qualquer outra para os acionistas da empresa. Esse resultado um tanto pessimista é a famosa proposição I de M \& M. 
A proposição II do mesmo estudo, conforme M \& M (1958, p. 271), afirma que: "the expected yield of a share of stock is equal to the appropriate capitalization rate Pkfor a pure equity stream in the class, plus a premium related to financial risk equal to the debt-to-equity ratio times the spread between $P k$ and $r$ "

$$
i_{j}=p_{k}+\left(p_{k}-r\right) D_{j} / S_{j}
$$

Essa Proposição diz que a taxa de retorno esperada por uma ação é formada por uma taxa esperada por ativos de mesmo risco, mais um prêmio pelo risco financeiro. Conforme Assaf Neto (2008, p. 467):

Essa proposição estabelece que o retorno requerido pelo capital próprio é uma função linear e constante do nível de endividamento... O acionista alavanca a taxa de capitalização dos recursos próprios em conformidade com o maior risco financeiro assumido.

O custo de capital próprio nesta proposição II é definido pela taxa de retorno requerido na situação de uma empresa sem dívidas, mais um prêmio pelo risco financeiro ao se incluir a participação de capital de terceiros. Esse prêmio se eleva à medida que cresce o endividamento.

O mesmo autor explica que apesar do custo crescente da taxa de capital próprio, como sua proporção no capital total diminui e o custo do capital de terceiros é constante, o custo total do capital (WACC) permanece constante para qualquer estrutura.

Esse primeiro artigo, como era de se esperar, gerou muita polêmica nos meios acadêmicos e financeiros. Autores como Durand (1959) e Solomon (1963) apontaram vários problemas nas proposições de Modigliani \& Miller. Durand (1959) criticou principalmente a maneira como os autores M \& M (1958) analisam o problema da arbitragem. Discute a dificuldade que no mundo real os investidores têm para tomar empréstimos à mesma taxa das corporações e promover alavancagem por conta própria.

Durand (1959) também mostra que várias restrições aos investidores como comissões de corretagem, impostos e outras limitações institucionais impedem que haja equilíbrio no mercado para a teoria funcionar a contento. $\mathrm{O}$ autor comenta também a dificuldade para enquadrar empresas na mesma classe de retorno numa economia capitalista altamente dinâmica. 
Em artigo publicado no ano de 1963, alguns meses antes da publicação do segundo trabalho de Modigliani e Miller, Solomon (1963, p. 276) comenta: "But in practice ki, the average rate of interest paid on debt, must rise as leverage is increased. For extreme leverage positions, i.e., as the company approaches an all-debt situation, it is clear that ki will be at least equal to ko.". Sendo que ki é o custo de capital de terceiros ko o do capital total usado pela empresa. Isso significa que a taxa de juros paga por títulos de dívidas não fica constante quando o endividamento aumenta. No limite, se todo o financiamento da empresa fosse feito por capital de terceiros, essa taxa ficaria pelo menos igual à taxa paga pelo capital total da empresa (WACC).

O mesmo autor explica que o custo marginal de endividamento em algum ponto começa a superar o custo de capital, e esse seria o limite de alavancagem admitido pela empresa. A conclusão de Solomon (1963, p. 279) é: "In short, the thesis that a company's cost of capital is independent of its financial structure is not valid." Com essa última frase o autor simplesmente considera inválida a proposição I de M \& M, mesmo sem levar em conta os efeitos de impostos.

No artigo de M \& M de 1963, as duas proposições são modificadas. Na proposição I o valor da empresa é acrescido do montante do capital de terceiros multiplicado pela taxa de imposto de renda devido pela empresa, conforme Assaf Neto (2008, p. 470):

Em trabalho posterior, Modigliani e Miller reconhecem que a dedutibilidade dos juros na apuração do Imposto de Renda a pagar favorece a dívida em relação ao capital próprio. Pela prática tributária vigente, a empresa tem a remuneração de seus credores abatida do Imposto de Renda a recolher, porém a legislação não permite que se adote o mesmo procedimento para com os pagamentos de dividendos sobre os lucros dos acionistas. Desse modo, mediante o uso de alavancagem financeira favorável é possível elevar-se o valor da empresa.

Na proposição II de M \& M (1963) o custo de capital próprio continua subindo na medida do endividamento, mas o custo total diminui por causa da dedutibilidade do imposto nas despesas financeiras. $\mathrm{O}$ que significa que o custo financeiro total da empresa não apenas ficaria constante, mas diminuiria com o aumento da alavancagem.

O que se passou a questionar a partir do artigo de M \& M (1963) é o motivo pelo qual as empresas não se endividam na maior proporção possível, formando seu capital com uma estrutura de, por exemplo, $99 \%$ de capital de terceiros e só $1 \%$ de capital próprio. Seguindo a lógica que mostra o crescimento do valor da empresa na proporção do maior emprego de 
capital de terceiros esse seria o comportamento esperado. Como, em geral, o nível de endividamento é bem menor do que o esperado pela teoria, a maioria dos trabalhos sobre estrutura de capital nas últimas décadas tenta explicar esse comportamento conservador das empresas.

Em estudo sobre a relevância da estrutura de capital, o valor da empresa e o custo do capital, Famá et al. (2001, p. 71) reproduzindo o trabalho de M \& M (1958) e utilizando dados de 101 empresas norte e latino-americanas de energia elétrica e 109 de petróleo e gás, no ano de 2000, chegaram a resultados interessantes, conforme os próprios autores:

Os resultados da pesquisa empírica não corroboram o modelo de M\&M de 1958. Na presença de um imposto de renda corporativo, a vantagem fiscal associada ao endividamento torna-o vantajoso para a empresa, permitindo a redução do custo médio de capital através de um aumento da alavancagem financeira, como os próprios M\&M demonstraram em 1963. Neste contexto os resultados obtidos não podem ser qualificados como surpreendentes.

Outro resultado obtido nesse mesmo trabalho, que diferentemente do de M\&M (1958) utilizou o CAPM para medir o custo do capital, é que, conforme Famá et al. (2001, p. 80), não foi detectada qualquer relação curvilínea entre nível de alavancagem e custo de capital que permitisse determinar níveis ótimos para estruturas de capital.

\subsection{Impostos e endividamento}

Num artigo publicado por Farrar e Selwyn (1967, p. 22), os autores chamam a atenção para outro aspecto importante relacionado ao segundo artigo de M \& M (1963), a possibilidade de alavancagem dos investidores relacionada com as tarifas de impostos corporativos e pessoais nos Estados Unidos:

By increasing corporate debt a firm presumably will increase its attractiveness to smaller investors (and more important, perhaps, to the institutional investors who channel funds from such persons into the capital markets). Lower debt firms, on the other hand, should be especially attractive to larger shareholders whose personal portfolios may contain considerable leverage.

Portanto uma empresa pode ser mais atrativa para pequenos investidores que, na visão dos autores, tem menos possibilidade de conseguir financiamentos mais baratos, se ela for mais alavancada. Por outro lado, empresas menos endividadas seriam mais interessantes para investidores maiores e mais alavancados. Isto é, o investidor que pode conseguir empréstimos 
mais baratos preferiria comprar ações mais de empresas com menos débitos junto a terceiros, que presumivelmente teriam preços mais baixos que outras mais endividadas, promovendo a alavancagem por conta própria.

Então, de acordo com Farrar e Selwyn (1967), o valor da firma pode ser afetado também pela estrutura de taxas de impostos de um país, que pode ser diferente para empresas e para particulares, e pela capacidade de alavancagem de diferentes investidores. Porque se todos tivessem possibilidade de se alavancar e se a vantagem fiscal do endividamento corporativo não fosse compensada pelo imposto individual, os investidores racionais sempre buscariam recursos mais baratos de terceiros para aplicar com vantagem nas empresas.

O próprio Miller (1977) ao levar em conta os impostos incidentes sobre credores e acionistas verificou que as vantagens na alavancagem da empresa não são tão vantajosos. E que poderia haver um novo equilíbrio, anulando as possíveis vantagens obtidas pelas empresas.

A relação dos impostos pagos pelas empresas com a alavancagem foi estudada também por Graham (1996, p. 41), que concluiu que as empresas com altas taxas marginais de impostos se endividam mais do que as que pagam menos. $\mathrm{O}$ autor verifica as taxas incrementais e os aumentos nos empréstimos para chegar ao seu resultado. O estudo aponta a falha nas pesquisas da área em não detectar essa influência.

Em uma pesquisa para verificar como o efeito dos impostos sobre dividendos e empréstimos afeta o valor das empresas, Fama \& French (1998, p. 819) não encontraram relação entre o nível de impostos da empresa ou do montante de pagamento de dividendos e o valor delas. Ao contrário da hipótese mais simples sobre impostos, que prevê relacionamento positivo entre empréstimos e valor da empresa e negativo com relação ao pagamento de dividendos, os autores encontraram correlação positiva para estes e negativa para o nível de empréstimos e o valor das firmas.

O mais interessante no artigo de Fama \& French (1998, p. 840) é forte relacionamento entre o valor pago em dividendos e o valor de mercado das empresas. Os autores mostraram que os dividendos trazem informações que outras variáveis como nível de empréstimos, receitas e investimentos não evidenciam. Esse efeito positivo da informação sobre dividendos obscurece qualquer possível conseqüência dos impostos sobre eles.

Outro resultado encontrado no trabalho de Fama \& French (1998), que está de acordo com Myers (1984), Myers \& Majluf (1984), e Miller \& Rock (1985), é que a alavancagem 
financeira, ao contrário do previsto por M \& M (1963), não traz vantagem líquida para o valor da empresa. Altos níveis de empréstimo inclusive deprimem a lucratividade e o valor da firma, principalmente por causa de problemas de agência, como previsto por Jensen \& Meckling (1976) e outros.

Graham (2000, p. 1935), ao contrário dos autores citados acima, encontrou evidências de que os empréstimos geram fortes benefícios fiscais, tendendo assim a aumentar o valor da empresa. No entanto o autor afirma que muitas grandes empresas, rentáveis, com boa liquidez e baixo nível de risco de estresse financeiro, usam capital de terceiros conservadoramente.

A literatura que relaciona o efeito dos impostos no financiamento das empresas foi revisada por Graham (2003, p. 43). De acordo com esse autor, a maioria das pesquisas mostra que a magnitude das taxas de impostos afeta as decisões financeiras das firmas, mas nem sempre de maneira significativa. Então, as empresas submetidas a altas taxas têm tendência a tomar mais empréstimos que as que pagam menos impostos. Vários outros efeitos de impostos são revisados nesse artigo, como os efeitos de impostos em filiais de multinacionais e sobre como os acionistas são afetados por pelas taxas pessoais, mas são assuntos que não serão analisados aqui.

O mesmo autor verifica que há algumas lacunas nos estudos, como, por exemplo, análises de séries temporais mostrando como mudanças em taxas de impostos em determinadas firmas, ou ramos industriais afetariam o comportamento financeiro dessas entidades. Aponta também o autor que pesquisas são requeridas para tentar explicar o comportamento aparentemente conservador em termos financeiros de muitas empresas.

A polêmica quanto à importância dos impostos para o endividamento das empresas, principalmente por causa da tributação dos dividendos e não tributação dos juros pagos, está longe de acabar. Pelo menos é o que se deduz da análise dos artigos publicados nos últimos decênios. Como foi visto, Miller (1977) e Fama \& French (1998), entre outros, defendem a irrelevância do nível de impostos para o endividamento. Já Farrar e Selwyn (1967), Graham (2000) e outros encontraram evidências de que há relacionamento positivo entre taxas de impostos e alavancagem financeira.

De qualquer forma, a variável "taxa de impostos" continua sendo, pelo menos teoricamente, a principal explicação para a vantagem que os empréstimos trazem para as entidades econômicas. Na própria hipótese de M \& M (1963), os impostos são os 
responsáveis pelo valor crescente da empresa em relação ao seu nível de alavancagem financeira.

\subsection{Custos de falência}

Em artigo publicado por Baxter (1967, p. 402), já considerando os custos associados ao risco de falência, o autor conclui que:

It has been argued above that the risks associated with excessive leverage will likely increase the cost of capital of the firm. A high degree of leverage increases the probability of bankruptcy and therefore increases the riskiness of the overall earnings stream. Since there appear to be very real costs associated with bankruptcy, other things equal, excess leverage can reduce the total value of the firm.

Então, de acordo com o autor, é que provável que o excessivo endividamento irá aumentar o custo de capital da empresa. Um alto grau de alavancagem aumenta a probabilidade de falência e também o risco de todos os fluxos esperados. Portanto, o excesso de endividamento pode reduzir o valor total da empresa.

O mesmo autor (Baxter, 1967) explica que o aumento do custo de falência não é diretamente proporcional ao endividamento, sendo mais do que compensado em estruturas pouco alavancadas pelo benefício fiscal das dívidas. Mas que tem grande influência em empresas muito endividadas. Mostra também que há diferenças entre empresas que têm grande variância nos lucros operacionais, mais sujeitas a riscos, e as mais estáveis, com menos custos relacionados à bancarrota.

Baxter (1967, p. 402), no artigo já citado, ainda não fala sobre um ponto de equilíbrio provável para a estrutura de capital em cada empresa ou mesmo para certos setores econômicos, mas é um dos primeiros a chamar de "custo de falência" a uma das forças restritivas à alavancagem excessiva das empresas.

Esse custo, ou o valor presente líquido dele, que é analisado e pesquisado em inúmeros trabalhos posteriores, está, de acordo com o mesmo autor, em parte diretamente relacionado com taxas, gastos jurídicos etc. Há ainda a parte indireta, que é a parte mais pesada da conta. Assim, à medida que a firma aumenta acima de certo limite seu endividamento, sua capacidade para enfrentar fatores adversos, que levem a uma queda de faturamento, diminui. 
Os credores, ao sentirem que há essa dificuldade, restringirão os aportes de capital e aumentarão as taxas cobradas.

Em um artigo de Warner (1977) são analisados os custos diretos de falência de algumas empresas ferroviárias. O autor considerou que esses custos não podem ser negligenciados em estudos sobre estrutura de capital, mas que são quase insignificantes em face da vantagem fiscal dos empréstimos. O problema é que não foram considerados os custos indiretos, que são difíceis de serem estimados mas que realmente pesam nas decisões de financiamento.

Altman (1984, p. 1071) citando os problemas encontrados no trabalho de Warner (1977), considera que o autor ignora os principais custos, tal como as perdas de oportunidades gerenciais, perdas de vendas e lucros, o alto custo de novos créditos e a dificuldade ou impossibilidade de obtenção de novos empréstimos ou emissão de ações.

No mesmo artigo, Altman (1984, p. 1087) conclui que os custos, principalmente os indiretos, não são triviais, sendo em média de $11 \%$ a $17 \%$ do valor da empresa nos três anos anteriores à falência, chegando algumas vezes a exceder $20 \%$ do valor de mercado da firma no período imediatamente anterior à bancarrota. O autor compara os custos esperados de estresse financeiro com as vantagens fiscais do endividamento e mostra que há um ponto em que eles se equilibram, conforme esperado pela teoria "Static Trade-off".

Opler \& Titman (1994, p. 1015) encontraram evidências de que firmas mais alavancadas, em caso de contração dos negócios no setor, sofrem em média mais perda de mercado que suas concorrentes financeiramente mais conservadoras. No período estudado os autores constataram queda de $26 \%$ a mais nas vendas nas empresas com maior nível de empréstimos que nas de menores níveis, sempre em épocas de diminuição de atividade (queda de vendas) no setor. $\mathrm{O}$ valor de mercado sofre queda similar nas mesmas circunstâncias. Empresas com produção mais especializada e as que investem mais em pesquisa e desenvolvimento, em época de estresse financeiro, sofrem mais quando são mais alavancadas. Os autores apontam que esses resultados confirmam a teoria de que os custos relacionados a estresse financeiro são positivos e relevantes.

Nos últimos tempos os chamados custos de falência, ou de estresse financeiro, perderam importância teórica para outros custos como o de agência ou mesmo os gerados pela assimetria de informação. Mas, da mesma forma que as taxas de impostos, esses custos continuam desempenhando seu papel nas decisões de financiamento das empresas. 


\subsection{Custos de agência}

Jensen \& Meckling (1976) iniciaram novas pesquisas em finanças quando analisaram o relacionamento entre o principal e o agente dentro de entidades econômicas. $\mathrm{O}$ principal poderia ser os donos da empresa (acionistas) e o agente os executivos, como diretores, gerentes ou o presidente da empresa. Os agentes tendem a agir em seu próprio interesse em detrimento dos principais. Por exemplo, o presidente de uma empresa pode se preocupar em perpetuar seu cargo, ou talvez se tornar conhecido como o principal responsável pelo alto crescimento dela durante sua administração. Esses e outros objetivos podem não ser os que fariam com que a riqueza dos acionistas fosse maximizada. A teoria também prevê custos diretos como os gastos dos principais para monitorar o agente ou os do agente para tornar conhecidas as suas ações, mas os custos mais altos são sempre os indiretos como os citados acima.

Um outro tipo de conflito, também previsto na teoria da agência, é o que pode ocorrer entre acionistas e credores. Os acionistas podem aplicar em projetos de alto risco, vender ativos sem um motivo plausível, pagar dividendos em vez de dívidas etc. Essas atitudes podem prejudicar os credores. Se, por exemplo, há a aplicação de valores tomados dos credores em projetos de alto risco os maiores prejudicados sempre serão os emprestadores. Porque caso o investimento dê certo os acionistas ganharão e pagarão somente os juros previstos no empréstimo mas, se der errado, e a empresa ficar em má situação financeira, os credores poderão perder o total dos empréstimos e os acionistas somente o valor residual.

Vários estudos procuram verificar a magnitude e como solucionar esses problemas de agência. Por exemplo, em um estudo sobre administradores que têm ações ou opções de compra desses papéis, Agrawal \& Mandelker (1987, p. 836) mostraram que a relação entre empréstimos e capital próprio é maior nas empresas em que os gerentes possuem maior participação no capital, ou opções de compra. De acordo com os autores, essa é uma maneira de diminuir os problemas de agência.

Um artigo que revisou grande parte da literatura sobre estrutura de capital foi escrito por Harris \& Raviv (1991, p. 299). Um dos focos desse artigo foi sobre a abordagem de custos de agência, em que conflitos de interesses entre grupos que disputam os recursos gerados pela empresa influem nas decisões de financiamento. 
Harris \& Raviv (1991, p. 300) citando Jensen \& Meckling (1976), explica que os dois tipos de conflitos identificados pelos autores são os de acionistas e administradores (diretores, presidentes ou outros altos cargos de direção) e os de emprestadores (bancos, debenturistas etc.) e acionistas.

Os administradores, marginalmente, não se sentem recompensados pelos esforços que realizam para que a empresa gere mais lucros e tenha seu valor aumentado. Então podem agir de modo que suas recompensas pessoais sejam majoradas e não empregar o trabalho necessário para otimizar os resultados da empresa. Quanto mais ações têm o administrador, menor o problema. Se a parcela de participação do gerente na empresa é constante, aumentar o total de empréstimos diminui o conflito com outros acionistas. Outras vantagens, apontadas em estudos posteriores, seriam a diminuição do fluxo de caixa livre por causa de pagamento de juros, restringindo a liberdade de gastos do administrador, e a obrigação de administrar com mais responsabilidade porque os empréstimos aumentam a possibilidade e os custos de falência.

Continuando a analisar os trabalhos sobre custos de agência, Harris \& Raviv (1991, p. 301) explicam que os conflitos entre acionistas e titulares de dívida estão relacionados com a tendência de se arriscar mais com recursos de terceiros que com próprios. Então, os acionistas poderiam, por exemplo, investir em projetos de alto risco, porque se der certo os retornos serão altos, mas se não, quem perderia, em última instância, seriam os credores.

Então, a estrutura ótima seria a que equilibrasse os benefícios dos empréstimos com os custos de agência. As implicações da teoria seriam (i) que os contratos de empréstimos poderiam ter cláusulas que previnam algumas atitudes que prejudicassem os credores, tal como impedimento para investimentos em linhas de negócios não relacionados aos atuais. (ii) Empresas com poucas oportunidades de crescimento provavelmente teriam maior participação de capital de terceiros em sua estrutura. (iii) Empresas sem perspectiva de crescimento e com grandes fluxos de caixa livres provavelmente devem ter maior alavancagem.

Citando vários autores, Harris \& Raviv (1991, p. 305) relacionam as implicações do modelo baseado em custos de agência. Em primeiro lugar a alavancagem da empresa seria diretamente relacionada com seu valor de mercado, probabilidade de falência, fluxo de caixa livre, valor de liquidação, possibilidade de que a empresa seja alvo de takeovers e reputação da alta administração. A alavancagem seria inversamente relacionada com o tamanho das oportunidades de crescimento, com a probabilidade de reorganização após concordata ou falência e com a capacidade de cobertura de juros entre outros fatores. 
Fatores apontados como determinantes da estrutura de capital nos modelos envolvendo conflitos de agência eram, de acordo com Harris \& Raviv (1991, p. 343), (i) valor da empresa que é positivamente relacionado com a alavancagem; (ii) empresas com menos oportunidade de investimento são mais endividadas; (iii) empresas mais lucrativas têm menos empréstimos; (iv) regulamentação em excesso tende a aumentar o uso de capital de terceiros; (v) fluxo de caixa livre aumenta a alavancagem (negado por pesquisa empírica); (vi) valor de liquidação positivamente correlacionado com endividamento. Outros fatores pesquisados, com menos evidências empíricas foram capacidade de cobertura de juros, importância da reputação dos gestores etc.

Maksimovic \& Zechner (1991, p. 1619) desenvolveram um modelo teórico que, diferentemente de quase todos os modelos referentes a custos de agência, leva em conta as interações em todo um setor industrial. Os autores explicam que:

In equilibrium the aggregate amount of debt in an industry adjusts, inducing investment decisions, such that the values of low-risk and high-risk projects are equal. As a result, although an individual firm's financial structure can influence investment decisions, it does not affect firm value.

Então, as decisões de investimento são provocadas pelos ajustes no montante de empréstimos do setor como um todo. Isso leva o valor dos projetos de alto e baixo risco a se igualar, tornando irrelevante a estrutura de capital da firma individual para a determinação de seu valor.

No equilíbrio, será indiferente para os proprietários se a empresa escolhe alto nível de endividamento e aplica em projetos de maior risco ou se usa mais capital próprio e aplica em projetos de mais baixo risco.

As previsões empíricas do modelo de Maksimovic \& Zechner (1991, p.1634) são que, em primeiro lugar, firmas de um mesmo setor industrial são indiferentes quanto à escolha de estrutura de capital. Segundo os autores, isso é consistente com dados empíricos que mostram que firmas similares de um mesmo setor têm diferentes níveis de endividamento.

Em segundo lugar, um resultado surpreendente, uma mudança para maior na taxa de impostos leva a mais endividamento e conseqüentemente a maior aplicação em projetos de alto risco. Isso provoca uma redução nos fluxos gerados por esses projetos. O que leva ao resultado aparentemente paradoxal de que as empresas que aplicam em projetos de risco 
diminuem seu endividamento, ao contrário das que aplicam em projetos de baixo risco, sempre em caso de aumento de impostos sobre resultado operacional.

Em terceiro lugar, empresas que usam tecnologia adotada pela maioria daquelas do mesmo setor são geralmente menos endividadas do que as que usam tecnologia escolhida por poucas.

Enfim, a importância de da pesquisa de Maksimovic \& Zechner (1991, p.1634) é que ela procura ver como se comportam as empresas de um mesmo setor industrial quando escolhem diferentes tipos de projetos, de maior ou menor risco, e também qual a influência dessa diferença de escolha nas suas decisões de financiamento.

Leland (1998) formula um modelo matemático que leva em conta em conjunto às teorias de Modigliani \& Miller (1963) e de Jensen \& Meckling (1976). A primeira que trata das vantagens fiscais e dos custos do endividamento e a segunda que verifica os conflitos entre acionistas e credores da empresa. O próprio autor explica a necessidade de se criar um modelo mais rigoroso levando-se em conta essas teorias, porque conforme Leland (1998, p. 1214): "A general theory must explain how both $J-M$ and $M-M$ concerns interact to determine the joint choice of optimal capital structure and risk."

Nesse estudo Leland (1998, p. 1237) chega a interessantes resultados. O custo de agência pela possível substituição de ativos é muito pequeno quando comparado às vantagens do endividamento. Inclusive o nível de endividamento necessariamente não cai quando há possibilidade de substituição de ativos, o que deveria ocorrer de acordo com as teorias mais aceitas. $\mathrm{O}$ autor verificou também que o custo de agência pode não estar diretamente e positivamente associado à escolha da estrutura ótima de capital.

\subsection{Fatores que influenciam a estrutura de capital}

Desde a intensificação das pesquisas sobre decisões de financiamento nas empresas, principalmente após o segundo artigo de M \& M (1963), há uma questão essencial que afeta todas as teorias e hipóteses de trabalho. A pergunta é: todas as entidades econômicas escolhem da mesma forma sua estrutura de capital? Todas as empresas tomam as mesmas decisões de financiamento nas mesmas circunstâncias, não importando suas particularidades? A resposta na maioria das vezes tem sido não. Essas decisões dependem de variáveis como o 
tamanho, a rentabilidade e vários outros fatores, endógenos ou exógenos, que especificam uma firma frente às suas concorrentes.

Esses fatores são tão importantes para a pesquisa que muitos trabalhos na área são realizados com a finalidade única de determiná-los e descobrir seus efeitos. Num artigo em que, talvez pela primeira vez, se verifica a importância dos imobilizados tangíveis (assets in place) e das oportunidades de crescimento na estrutura de capital, Myers (1977, p. 1) comenta:

There is an important gap in modern finance theory on the issue of corporate debt policy. The theory should be able to explain why the tax advantages of debt financing do not lead firms to borrow as much as possible, and it should explain the phrase "as much as possible." It should explain why some firms borrow more than others, why some borrow with short, and others with long-maturity instruments, and so on.

Portanto, a teoria não explica a política de endividamento das empresas. Porque, apesar das vantagens apontadas no artigo de 1963 de M \& M, as firmas não procuram se endividar o máximo possível. Porque algumas se endividam mais, outras menos, algumas com créditos de longo e outras de curto prazo.

O mesmo autor (Myers, 1977: p.1) aponta as causas possíveis. Referindo-se a M \& M (1963), escreve que os autores se voltam para uma possível 'capacidade de endividamento reserva' que as empresas manteriam. Ou ainda a taxas de impostos sobre ganhos de capitais de pessoas físicas, que reduzem as vantagens da alavancagem.

Continuando, sempre com base na literatura precedente, Myers (1977, pp. 1,2) cita a possibilidade de que mercados incompletos ou imperfeitos limitem o endividamento. $\mathrm{Ou}$ ainda que bancos e outros credores restrinjam o crédito. Outra possível explicação é que administradores evitem dívidas para se proteger. Há também os custos de falência ou estresse financeiro. Todos esses e outros motivos, segundo o autor, não explicam totalmente o problema.

Como possível explicação Myers (1977) propõe nova teoria que relaciona o endividamento com os ativos já instalados (asset-in-place), que são financiados mais com dívidas do que as oportunidades de crescimento, medidas por despesas discricionárias, relacionadas com o futuro da empresa (intangíveis). Para os ativos já instalados, os que mais atraem dívidas são os que (i) usam capital intensivo e os que (ii) produzem alta lucratividade. 
O comportamento da firma seria então diferente nos casos em que tem que assumir riscos em decorrência de novas dívidas. Muitas vezes ela poderia optar por não investir, mesmo com valor presente líquido positivo, se tiver que emitir passivos com risco. Nas palavras do próprio Myers (1977, 3):

Thus part of the value of a firm is accounted for by the present value of options to make further investments on possibly favorable terms. This value depends on the rule for deciding whether the options are to be exercised. The paper shows that a firm with risky debt outstanding, and which acts in its stockholders' interest, will follow a different decision rule than one which can issue risk-free debt or which issues no debt at all. The firm financed with risky debt will, in some states of nature, pass up valuable investment opportunities - opportunities which could make a positive net contribution to the market value of the firm.

Parte do valor de uma empresa seria formado pelo valor presente das opções de realizar possíveis investimentos em condições favoráveis. Uma empresa então tomaria diferentes decisões, seguiria regras diferentes, dependendo de ter possibilidades se financiar com ou sem risco. Empresas que precisam se financiar com risco, em algum momento, poderiam deixar passar oportunidades de investimento com valor presente líquido positivo.

Ainda de acordo com Myers (1977), os investimentos são opções a serem exercidas ou não dependendo também dos ativos possuídos pela firma. Os ativos da empresa já instalados podem ser financiados porque representam fluxos de caixa que serão obtidos com um grande grau de certeza, mas novos investimentos, principalmente em intangíveis, ou outros com grandes riscos associados, muito provavelmente levarão a empresa a agir com mais cautela.

Um estudo de Titman \& Wessels (1988, p. 17) mostrou que os custos de transação também são importantes na determinação da estrutura de capital. O volume de débitos de curto prazo está negativamente relacionado com o tamanho das empresas, possivelmente refletindo os relativamente altos custos que empresas menores têm para emitir empréstimos de longo prazo. Outro fator apontado nesse estudo é que a dependência da empresa em relação a um só ou poucos produtos tende a influenciar sua estrutura de capital. Essas firmas, que geralmente apresentam riscos mais altos para clientes, fornecedores e empregados, normalmente têm índice entre empréstimos e capital próprio menor.

Nesse mesmo trabalho Titman \& Wessels (1988, p. 17) também encontraram evidências de que empresas mais lucrativas apresentam menor percentual de endividamento, 
tanto de curto como de longo prazo, confirmando a POT. Não foi encontrada relação entre expectativa de crescimento e estrutura de capital. Também não houve comprovação de influência de volatilidade dos lucros na determinação do endividamento.

Harris \& Raviv (1991, p. 319) verificaram que as pesquisas sobre estrutura de capital de empresas baseadas em tipos de produtos ou estratégias de mercado ainda eram incipientes na época. Mas as pesquisas apontavam naquela data que firmas oligopolistas, nos setores competitivos, tinham relativamente mais empréstimos do que as monopolistas. Provavelmente, empresas de produto único, ou que prestam serviços especializados de alta qualidade, também eram menos alavancadas.

Em importante artigo, em que investiga como débitos protegidos por cláusulas especiais, como debêntures com condições que protegem os credores (bond covenants), diferem de outros empréstimos na escolha da estrutura de capital, Leland (1994, p. 23) conclui que a alavancagem ótima para empresas com esses empréstimos é substancialmente menor que para outras com débitos emitidos sem essas cláusulas. Também as taxas de juros são menores do que para empréstimos não protegidos, mesmo com custos de falência positivos. $\mathrm{O}$ valor máximo alcançado pela firma no mercado, que é elevado pelo nível de empréstimos, atinge um valor menor quando a empresa se utiliza desses débitos com cláusulas protetoras.

Em estudo sobre a maturidade dos empréstimos em empresas americanas, Stohs \& Mauer (1996, p. 281) verificaram uma correlação negativa entre a volatilidade dos lucros e a maturidade média dos empréstimos das empresas, com as taxas efetivas de impostos e com o risco das firmas. Já a correlação com a maturidade dos ativos foi positiva para as empresas estudadas, isto é, empresas com ativos de maior duração em média tomam empréstimos mais longos.

Uma linha de pesquisa diferente e pouco utilizada na literatura sobre estrutura de capital é a de Faulkender \& Petersen (2006, p. 74). Os autores procuram verificar em que medida as fontes de capital de terceiros influenciam a alavancagem das empresas. Empresas que têm "debt rating" e portanto acesso ao mercado de bonds (nos Estados Unidos) em média são mais endividadas do que as que não têm. Essa referência às fontes de financiamento ajuda a explicar em parte o porquê da maior alavancagem de grandes empresas, porque elas geralmente são mais bem classificadas pelas agências de risco.

Um estudo publicado por Frank \& Goyal (2007, pp. 1-59) sobre os fatores que impactam a estrutura de capital das empresas, realizado com dados publicados pelas empresas 
de capital aberto americanas entre 1950 e 2003, mostrou que a alavancagem média do setor industrial, a razão entre preços de mercado e de livro das ações, a tangibilidade dos ativos, a lucratividade, o tamanho das empresas e a expectativa de inflação são os seis fatores que mais influenciam o nível de endividamento das empresas. Muitos outros fatores também influenciam a estrutura de capital das empresas, mas são bem menos significativos do que os apontados. Há também mudança na importância dos fatores ao longo do tempo, por exemplo a lucratividade que foi muito importante nos anos 80 , teve bem menos influência nos últimos anos da pesquisa.

A conclusão do estudo de Frank \& Goyal (2007, p. 32) é que empresas de setores industriais que têm alta alavancagem, tendem a ter alta porcentagem de empréstimos em relação ao capital próprio. Da mesma forma, empresas cujo preço de mercado é bem superior ao de livro, aquelas que têm altos valores de ativos tangíveis, e as grandes empresas também apresentam a tendência a ter altas taxas de capital de terceiros. Já aquelas firmas com alta lucratividade tendem a ter baixa alavancagem. $\mathrm{O}$ fator exógeno inflação tende a influir em todas as empresas. Em média, a previsão de alta inflação leva as empresas a se endividarem mais.

Rajan \& Zingales (1995, p.1422) mostraram que os países participantes do G-7 em geral têm os mesmos determinantes para estrutura de capital das empresas americanas. Uma diferença encontrada é que o tamanho da empresa não tem correlação positiva com o endividamento na Alemanha, ao contrário de todos os outros países do grupo. A lucratividade é negativamente correlacionada com a alavancagem em todos os países, exceto novamente na Alemanha. A razão entre preço de mercado e de livro, que é uma proxy para oportunidades de investimentos, é negativamente correlacionada em quase todos os países, exceto na Itália.

Em estudo com as 500 maiores empresas da América Latina, Famá e Melher (1999, p. 14) encontraram evidências contrárias ao estudo acima, verificando correlação positiva entre rentabilidade e endividamento. De acordo com esses autores, o nível de endividamento alavanca tanto os lucros nas rentáveis como o prejuízo nas deficitárias.

Booth et al. (2001, p. 117) concluíram que os fatores que explicam as diferentes estruturas de capital nas empresas de países em desenvolvimento, geralmente, são os mesmos dos países desenvolvidos. Confirmaram inclusive que de acordo com a POT as empresas mais rentáveis, em média, são menos endividadas em relação ao capital próprio. Mas há variações entre os países que, de acordo com os autores, poderiam ser mais bem explicadas 
conhecendo-se melhor as variáveis externas às empresas, como o PIB ou o grau de desenvolvimento do mercado de capitais etc.

\subsubsection{Comportamento dos fatores de acordo com a POT}

Conforme previsto na POT, na versão mais simples, quanto mais lucrativa a empresa menos endividada ela tende a ser. No entanto, conforme discutido por Myers (1984), uma interpretação mais complexa da teoria prevê que as empresas podem reservar uma capacidade de endividamento para o futuro. Dessa forma, evitando que mais tarde tenham que recorrer a empréstimos com taxas mais elevadas ou mesmo a emissões de ações, as empresas poderiam manter um nível de endividamento baixo. Então, num mesmo nível de lucratividade, as empresas com expectativa de maiores investimentos futuros tenderiam a ser menos endividadas que as outras.

Nesta dissertação só será levada em conta a versão mais simples e portanto será sempre suposto que as empresas mais lucrativas tendem a ser menos alavancadas. Outra questão que não está sendo analisada neste trabalho mas que alguns autores, como Fama \& French (2000), deduzem da mesma teoria é que empresas mais lucrativas tendem a pagar mais dividendos, sendo que esses pagamentos são negativamente relacionados com as oportunidades de investimento e nível de endividamento.

A questão do tamanho da empresa é também muito controvertida, mas na maioria das vezes, como por exemplo em Myers (1984), há um relacionamento positivo entre esse fator e o endividamento da empresa. As firmas maiores, geralmente grandes corporações, têm menos possibilidade de falir e portanto seus custos de falência são menores. Elas geralmente conseguem empréstimos mais baratos, porque podem dar maiores garantias aos bancos ou outros credores. Esse tipo de empresa também tem mais acesso a diferentes tipos de financiamentos, tanto de bancos como através de bonds (debêntures). Tanto na POT como na STT, na maioria dos estudos, o relacionamento entre tamanho e endividamento é positivo.

A volatilidade dos fluxos de caixa tende também a diminuir a alavancagem das empresas. Entre outros autores, Fama \& French (2002) afirmam que firmas que têm alta variância nos fluxos de caixa tendem a manter níveis mais baixos de endividamento para que, no caso de baixos fluxos, não serem obrigadas a tomar empréstimos mais onerosos. Esse comportamento da volatilidade em relação ao nível de empréstimos é defendido tanto pela POT como pela STT. 
O tipo de ativo também é mencionado em muitos trabalhos, como por exemplo em Titman \& Wessels (1988). Ativos que podem servir como garantia para empréstimos mais vantajosos para as empresas tendem a levá-las a se endividar mais. Muitos tipos de ativos, mesmo intangíveis, podem servir para esse fim. Mas a maioria dos pesquisadores examina a questão da tangibilidade ou não dos ativos das empresas, buscando verificar se essa questão está ligada com o nível de débitos.

Long \& Malitz (1985), Harris \& Raviv (1991), Frank \& Goyal (2002) e outros pesquisadores chegaram à conclusão de que a tangibilidade dos ativos é positivamente relacionada com a alavancagem. Quanto mais uma empresa tem ativos intangíveis, menor é a tendência de se endividar. Pesquisas usando como proxy investimentos em propaganda e marketing e em pesquisa e desenvolvimento têm mostrado essa tendência. Ao contrário, empresas que têm grande parte de seus ativos em bens tangíveis são mais endividadas. Uma das explicações é que esses próprios ativos servem de garantia para empréstimos mais vantajosos, tendo em vista o baixo risco desse tipo de operação.

Firmas que têm grandes oportunidades de crescimento também tendem a se endividar menos. Uma das explicações é que elas preferem manter a capacidade de financiamento de baixo risco para os futuros investimentos. Long \& Malitz (1985) ao contrário de Titman \& Wessels (1988) constataram essa tendência. De toda forma, essa é uma questão polêmica que não está ainda totalmente decidida. Mas nesta dissertação, considerando a relação entre preço de mercado e de livro como proxy para capacidade de crescimento, o ponto de vista adotado será o mais tradicional, apoiado pela POT, que prevê menor alavancagem para empresas com maior capacidade de crescimento.

\subsubsection{Comportamento dos fatores de acordo com a STT}

A primeira expectativa sobre o comportamento das empresas na STT é sobre a magnitude da taxação. Então, empresas que tivessem taxas de impostos sobre a renda mais altas usariam proporcionalmente mais dívidas para se protegerem. Graham (1996) obteve evidências de que empresas com taxas marginais de impostos mais altas tem tendência a se endividar mais. A principal linha de argumentação da teoria que defende um nível ótimo de endividamento é que as empresas obteriam vantagens pagando menos impostos com o uso de 
dívidas. Essas vantagens aumentariam o valor da empresa até o ponto em que os riscos, principalmente de falência, se igualassem aos ganhos.

Outra previsão da STT é que quanto mais lucrativas mais alavancadas deveriam ser as empresas. Um dos motivos é que mais lucros significam mais impostos e, portanto, maior alavancagem financeira seria necessária para contrabalançá-los. Outro motivo é que a maior lucratividade diminuiria o custo do estresse financeiro possibilitando maior endividamento. Essa é uma das previsões da STT que mais fortemente se opõe a da POT simples, que prevê exatamente o contrário. Myers (1984), Titman \& Wessels (1988) e Fama \& French (2002), entre outros autores criticaram essa idéia e não encontraram evidências dessa tendência.

A STT também defende que oportunidades de crescimento aumentam o estresse financeiro e portanto diminuem o endividamento da empresa. Essa tendência é a mesma prevista pela POT, mas por motivos diferentes. No caso da POT é por causa da possibilidadeda empresa necessitar de futuros financiamentos de baixo risco a menor custo.

Como já foi visto neste estudo, o tamanho provavelmente também é positivamente correlacionado com a alavancagem. Tanto a STT como a POT prevêem que empresas maiores tenham tendência a usar mais débitos em relação a capital próprio. Os principais motivos são menores custos de falência e maior acesso a fontes menos onerosas de financiamento.

Comparando as previsões sobre os quatro fatores que serão examinados nesta pesquisa que são o tamanho, a lucratividade, a tangibilidade e a oportunidade de crescimento, vemos que há muita controvérsia e que, na maioria das vezes, a única tendência que diferencia as duas teorias a serem comparadas é a lucratividade.

É que, a princípio, a POT não faz previsão sobre níveis de alavancagem e considerava que o nível de endividamento seria simplesmente consequiência de déficits financeiros não cobertos com o fluxo de caixa operacional da empresa. Daí a previsão de que gerando mais caixa interno a empresa recorrerá menos a empréstimos e ficará menos alavancada, pelo menos nas interpretações mais simples da POT.

\subsection{O que pensam os dirigentes de empresas}


Em pesquisa com 392 diretores financeiros de empresas americanas, Graham \& Harvey (2001, p. 188) encontraram evidências de que as maiores empresas usam cotidianamente conceitos tais como custo de capital (CAPM) e valor presente líquido (NPV), mas não se preocupam com as teorias referentes à estrutura de capital. Talvez, como explicado pelos autores, porque não há ainda uma teoria conclusiva a respeito do assunto. Informações tais como flexibilidade financeira e classificação da empresa por agências de risco são mais importantes na tomada de decisões de financiamento.

Outra pesquisa realizada com 313 diretores financeiros de empresas de quatro países europeus, Brounen, Jong \& Koedijk (2005, pp. 1-34) encontraram fortes semelhanças com comportamentos detectados em estudos realizados anteriormente nos Estados Unidos. Há um comportamento parecido com o previsto na "pecking order theory", mas o que prevalece é a "static trade-off theory", principalmente pela existência de metas para endividamento e também por considerações sobre os benefícios e custos do uso de capital de terceiros. Os autores também encontraram evidências de que as empresas de capital aberto preferem emitir ações quando seus preços estão altos. Não houve evidências de que problemas de agência ou assimetria de informações tivessem qualquer papel nas decisões de financiamento das firmas estudadas.

\subsection{A procura por uma estrutura ótima de capital}

Antes de M \& M (1958) já havia, mesmo que de forma não explicita, uma procura por uma estrutura de capital que trouxesse o máximo de ganhos, como vantagens fiscais e um custo mais baixo de capital, e o mínimo de perdas com estresse financeiro. Haveria então um ponto ótimo em que as perdas marginais pelo aumento de capital de terceiros se igualassem aos ganhos marginais com endividamento.

Durand (1959), Solomon (1963) e outros continuaram questionando a indiferença quanto à estrutura defendida no primeiro artigo de $M$ \& M (1959). Depois do artigo de M \& M (1963), a maioria dos trabalhos em finanças passou a verificar quais as causas que impediam as empresas de aumentar seu valor se endividando indefinidamente. Os valores presentes dos custos de falência (diretos e indiretos) e os custos de agência foram eleitos como os principais problemas no financiamento das empresas. 
Duas décadas após o segundo artigo de M \& M, Bradley, Jarrel \& Kim (1984, p. 876) publicaram um trabalho que procurou analisar vários fatores que influenciam a estrutura de capital das empresas. Em primeiro lugar, o efeito das taxas de impostos pessoais sobre ganhos de capital e de empréstimos (bonds). Juntamente com esses impostos, os custos de estresse financeiros, que os autores identificam como custos de falência e de agência. Um terceiro fator foi os benefícios fiscais não relacionados à dívida.

Os resultados de Bradley et al. (1984, p. 876) foram que o nível ótimo de empréstimos é inversamente relacionado com os custos esperados de estresse financeiro e diretamente com o montante de benefícios fiscais não financeiros. Quando os custos de estresse financeiro são significativos, a alavancagem é inversamente proporcional à variância dos lucros operacionais da empresa. Os autores também encontraram evidências de que há influência do setor industrial ao qual a empresa pertence e seu nível de endividamento. Os gastos intensivos em propaganda e pesquisa e desenvolvimento também são inversamente relacionados com a alavancagem.

Todos esses resultados encontrados por Bradley et al. (1984) são consistentes com o previsto na teoria de nível ótimo de estrutura de capital (STT), menos o forte relacionamento direto entre o montante de benefícios fiscais não financeiros e o nível de endividamento. Apesar desse problema, os autores concluem que:

Nonetheless, the strong finding of intra-industry similarities in firm leverage ratios and of persistent inter-industry differences, together with the highly significant inverse relation between firm leverage and earnings volatility, tends to support the modern balancing theory of optimal capital structure

Então, principalmente pela similaridade nos níveis de endividamento de um mesmo setor industrial, junto com a significante correlação inversa entre volatilidade de lucros operacionais e nível de endividamento, há evidências para suportar a teoria de que há uma estrutura ótima de capital que equilibre os custos e benefícios das dívidas.

Alguns anos depois, baseados num modelo proposto por DeAngelo \& Masulis (1980), que leva em conta impostos pessoais e das empresas, Kale et al.(1991, p. 1693) mostraram que o relacionamento entre nível ótimo de endividamento e o risco das empresas é aproximadamente em forma de "U". Isto é, partindo dum nível alto para empresas de baixo risco, o nível ótimo vai caindo à medida que o risco aumenta, mas a partir de certo ponto volta a crescer. Os autores desenvolveram um modelo matemático em que o direito do governo 
sobre os impostos das empresas é tratado como uma opção, da mesma forma que a obrigação de pagar impostos pelos detentores de títulos de débito.

Então, sempre de acordo com Kale et al. (1991, p. 1694), há um ponto ótimo de endividamento, de acordo com o risco da empresa, em que a soma desses pagamentos de impostos, da empresa e dos credores, é minimizada. O resultado é corroborado por dados empíricos apresentados pelos autores.

Em artigo teórico em que discutem as polêmicas que envolvem o assunto, Famá e Grava (2000, p. 32) reafirmam que o tema está "longe de conclusivo". Mas defendem que a teoria de estrutura ótima, em que as vantagens marginais proporcionadas pelo endividamento se igualam aos custos marginais relacionados ao estresse financeiro, é a que melhor explica a realidade.

Hovakimian et al. (2001, p. 1) estudaram a busca de uma estrutura ótima levando em conta que ela pode se modificar ao longo do tempo, de acordo com mudanças na lucratividade e no preço das ações. Dentro dessa dinâmica, em que a meta pode variar, os autores encontraram evidências a favor da teoria da estrutura ótima (STT). Outra descoberta interessante é que a meta é buscada mais por meio de recompra de ações e títulos de dívida do que por novas emissões.

Em um estudo que procura verificar empresas que emitem ações e títulos de débito ao longo do tempo, Hovakimian et al. (2004, p. 517) encontraram evidências que concordam com a "Dinamic Tradeoff Theory", isto é, as firmas emitiriam ações ou dívidas sempre que se desviassem da meta, buscando o valor ideal para a estrutura de capital. De acordo com os mesmos autores, as empresas pesquisadas que têm alta oportunidade de crescimento (geralmente empresas de altos índices entre preços de mercado e de livro) também têm baixas metas de endividamento.

Ainda de acordo com a mesma pesquisa de Hovakimian et al. (2004, p. 532), a lucratividade não tem relação, nas empresas estudadas, com a alavancagem. Embora empresas não rentáveis emitam ações para compensar o excesso de endividamento, as rentáveis não emitem dívidas para compensar o excesso de capital próprio, preferindo muitas vezes usar fundos gerados internamente (pecking order). As empresas também aproveitariam as altas das ações para fazer novas emissões (market timing). A conclusão dos autores é que, embora em média as empresas tenham uma estrutura de capital alvo, a tentação de aproveitar as altas para novas emissões de ações e o uso de fundos internos interferem na manutenção da meta. 
Flannery \& Rangan (2004, p. 2) também concordam que as empresas buscam ajustarse em torno de uma meta ideal para a estrutura de capital. Procurando estimar com se dá esse ajuste os autores encontraram que o ajuste se dá em torno de um terço da diferença entre a porcentagem atual e a meta esperada para a empresa em média. Essa porcentagem é três vezes maior do que muitas estimativas de estudos anteriores. Diferentemente de Welch (2004), os autores consideram que os efeitos das mudanças nos preços de ações têm efeito somente temporário na estrutura de capital.

Leary \& Roberts (2005, p. 2613) verificaram que o comportamento das empresas em torno do nível de alavancagem "ideal" pode ser explicado pela presença de custos de ajustamento. Diferentemente de Welch (2004), os autores encontraram evidências de que não há indiferença quanto à estrutura de capital, mas que o comportamento das empresas procura diminuir os custos associados à emissão ou recompra de ações e dívidas. As conclusões dos autores são consistentes tanto com a POT modificada quanto com a estratégia de ajustes dinâmicos na estrutura de capital.

A conclusão mais importante de Leary \& Roberts (2005, p. 2577) é que as empresas geralmente procuram ativamente ajustar sua alavancagem para se manter dentro de uma faixa considerada ótima. Firmas que por decisões passadas tenham aumentado muito a participação de capital de terceiros tendem a diminuir a alavancagem e vice-versa.

Fischer et al. (1989, p. 38) estudaram a formação da estrutura de capital, levando-se em conta os custos e benefícios da alavancagem, mas de uma forma dinâmica, considerando os custos de recapitalização e as faixas de variações do endividamento em relação ao capital próprio. Uma das conclusões é que empresas menores, de maior risco, com taxas mais baixas de impostos e menores custos de falência têm grandes oscilações em seu percentual de endividamento durante todo o tempo.

Welch (2004, p. 106) utilizando um modelo que leva em conta os valores de livro para os empréstimos e o de mercado para o capital próprio, conclui que a variação do preço das ações pode explicar aproximadamente $40 \%$ das modificações na estrutura de capital das empresas. A lógica usada nesse artigo é relativamente simples, as empresas não buscam mais empréstimos simplesmente para contrabalançar o aumento do preço de suas ações, e também não pagam débitos remanescentes quando há baixa em seu preço de mercado. Portanto, muito da mudança na relação entre empréstimos e preço de capital próprio no mercado pode ser explicado pela variação dos preços das ações. 
Outro trabalho publicado por Kayhan \& Titman (2004, p. 32) encontra evidências de que as empresas têm uma meta ótima de endividamento em relação ao capital próprio, mas que há significativos desvios desse nível em razão das variações do preço das ações, da necessidade de investimentos e do fluxo de caixa gerado operacionalmente. Nas palavras dos autores:

The results in this paper support the view that firms behave as though they have target debt ratios, but their cash flows, investment needs and stock price realizations lead to significant deviations from these targets. Our results indicate that the capital structures of firms do move back towards their targets, but the rate at which they do this is relatively slow. In this sense, our evidence is consistent with the dynamic capital structure models presented in Fischer, Heinkel, and Zechner (1989) and Titman and Tsyplakov (2004) that show that, with reasonable levels of transaction costs, along with the traditional costs and benefits of debt financing, debt ratios will vary over a relatively large range.

Então, de acordo com os autores, a taxa em que essa variação em torno da meta é lenta quando há desvios provocados pelos fatores já citados. Na conclusão do trabalho os autores, Kayhan \& Titman (2004, p. 33), explicam que as variações nos preços das ações têm um efeito mais permanente na estrutura de capital do que os déficits financeiros. Esse efeito, de acordo com os autores, pode ser associado a alterações na meta ótima de endividamento. Uma das possíveis explicações é que o alto retorno das ações pode estar associado ao crescimento das oportunidades de crescimento da empresa.

\subsection{Informações assimétricas e a hierarquia das fontes de financiamento}

Admitindo-se que o mercado é imperfeito, sempre haverá discrepâncias entre as informações conhecidas por investidores, financiadores e administradores de empresas. Baseados nessa constatação (ou suposição), Myers (1984) e Myers \& Majluf (1984) deram início a uma nova linha de pesquisas em que se procura verificar quais são as fontes de financiamento mais vantajosas para as empresas.

Em poucas linhas, a teoria é a seguinte: os administradores (presidentes, diretores e gerentes) conhecem melhor a empresa do que possíveis acionistas e outros financiadores. Para eles e também para os que já são acionistas é sempre melhor usar fundos gerados operacionalmente, que são obviamente os mais baratos. Caso esses fundos não cubram os 
novos investimentos necessários, buscam-se empréstimos e quase nunca novos acionistas. Isso porque ao lançar novas ações no mercado elas serão quase sempre subavaliadas pelos novos investidores.

Em artigo de Myers \& Majluf (1984), os autores analisam as decisões de financiamento de empresas quando os gestores têm mais informações do que os investidores, atuais ou potenciais. Nesses casos, é mais vantajoso o financiamento com geração interna de recursos, seguido de assunção de dívida. Não se emitem ações, sob pena de queda de preços e perda de valor da empresa, prejudicando os atuais acionistas. Sempre ressaltando que isso acontece pela assimetria de informações. Apesar de não ser usado o termo, temos nesse artigo uma espécie de Pecking Order Theory forte, que não admite a emissão de ações para financiamento de novos investimentos.

Fazzari et al (1987, p. 30), em um estudo usando a teoria Q de investimento, também chamada Q de Tobin, mostrou que empresas em desenvolvimento em setores industriais de alto crescimento tendem a se utilizar da hierarquia de financiamento (POT) mais fortemente, porque frente a assimetrias de informação seu financiamento externo é muito caro. Há também, de acordo com os mesmos autores, empresas pequenas que sofrem as mesmas restrições. Essas empresas têm o fluxo de caixa gerado operacionalmente como uma fonte ótima de investimento, e sofrem restrições quando necessitam de investimentos que ultrapassem esse limite.

No artigo de Harris \& Raviv (1991, p. 315), uma das abordagens foi a das informações assimétricas. As diferenças de conhecimentos sobre a empresa podem levar a decisões que, às vezes, não são as melhores para todos. Os principais trabalhos nesse campo são relacionados com as variações de preços das ações quando as empresas mudam a estrutura de capital e também com o uso ou não da pecking order pelas firmas.

Diversas pesquisas, ainda de acordo com Harris \& Raviv (1991), apontavam não reação do valor da empresa na emissão de títulos sem riscos ou uso de recursos internos para investir, mas o preço abaixava na emissão de novas ações ou títulos com risco. Quanto à hierarquia de fontes de financiamento, algumas pesquisas apontavam a preferência sempre por recursos internos, seguidos por empréstimos e quase nunca emissão de ações (pecking order). Outras investigações não concordavam com essa hierarquia de fontes.

Harris \& Raviv (1991, p. 345) explicam ainda que nas teorias que levam em consideração a assimetria de informações alguns modelos previam que os preços de mercado 
das ações não seriam afetados por aumento no endividamento, mas a maioria das provas empíricas era contrária a essa conclusão. Outros fatores eram a lucratividade, o fluxo de caixa livre, valor da empresa, possibilidade de falência, posse de mais ações pelos gestores etc. Com exceção do fluxo de caixa livre todos os outros fatores eram, quando da publicação do artigo, positivamente correlacionados com a alavancagem.

Harris \& Raviv (1991, p. 345) explicam ainda que nas teorias que levam em consideração a assimetria de informações alguns modelos previam que os preços de mercado das ações não seriam afetados por aumento no endividamento, mas a maioria das provas empíricas era contrária a essa conclusão. Outros fatores eram a lucratividade, o fluxo de caixa livre, valor da empresa, possibilidade de falência, posse de mais ações pelos gestores etc. Com exceção do fluxo de caixa livre todos os outros fatores eram, quando da publicação do artigo, positivamente correlacionados com a alavancagem.

Um resultado que contraria muitas das pesquisas citadas anteriormente é o encontrado por Frank \& Goyal (2002, pp. 1-39). Nesse artigo em que os autores testam a Pecking Order Theory (POT), para uma grande quantidade de empresas entre os anos de 1971 e 1998, os autores, contrariamente a Shyam-Sunder \& Myers (1999) e outros, encontraram evidencias contrárias à hierarquia de fontes defendida pela POT. Segundo os autores, Shyam-Sunder and Myers usaram dados de somente de 157 firmas, amostra pequena dentro do universo de empresas de capital aberto norte-americanas.

Na mesma pesquisa Frank \& Goyal (2002, p. 3) escrevem que nos anos 80 e 90 o financiamento externo das empresas americanas é muito maior do que aceito pela POT e que o valor captado com a emissão de ações muitas vezes excede o volume de novos empréstimos.

Outro resultado interessante encontrado por Frank \& Goyal (2002) é que mesmo em firmas submetidas a fortes pressões advindas da seleção adversa, como empresas pequenas e de alto crescimento (geralmente novas), não há o comportamento esperado pela POT. Pelo contrário, empresas grandes e estáveis é que seguem, em média, o modelo proposto pela teoria.

Outro grande problema para a aceitação da POT surgiu com a publicação de pesquisa realizada por Fama \& French (2005, p. 580). Os autores encontraram evidências de que, ao contrário do previsto pela teoria, a maioria das empresas americanas, independentemente do tamanho, têm emitido ações quase que anualmente e em proporções significativas em relação 
aos novos empréstimos. Um dos motivos encontrados para explicar o comportamento é que grande parte das novas ações não é emitida em novas ofertas públicas, mas sim como plano de opções para empregados e executivos, vendas diretas e outras formas. Essas emissões não propiciam a assimetria de informações que levam as empresas a preferir outras formas de financiamento.

De acordo com o mesmo artigo de Fama \& French (2005, p. 580) a POT como uma teoria que explique o comportamento das empresas na escolha da estrutura de capital está morta. Mas, da mesma forma, os autores apontam grandes falhas na teoria rival, que não explica, por exemplo, a relação negativa entre rentabilidade e alavancagem, mostrada entre outros por Titman \& Wessels (1988), Rajan \& Zingales (1995) e Fama \& French (2002). Em suma, as duas teorias têm sérios problemas e talvez o melhor, de acordo com os autores, seja aproveitar as partes boas das duas para tentar explicar o real comportamento das empresas na escolha da estrutura de capital.

\subsection{Pecking Order Theory X Static Trade-off Theory}

No artigo The Capital Structure Puzzle escrito por Myers (1984, p. 575), o autor pergunta: "How do firms choose their capital structures?" Again, the answer is "We don't know." O que significa que a escolha da estrutura de capital, apesar de tudo o que já fora escrito até aquela data, ainda continuava sendo uma grande incógnita. Foi nesse artigo que talvez pela primeira vez um autor compara as teorias conhecidas como Pecking Order Theory e Static Tradeoff Theory. Nas próprias palavras do autor (Myers, 1984, p. 576):

...I take this opportunity to make amends, and to try to push research in some new directions.

I will contrast two ways of thinking about capital structure:

1. A static tradeoff framework, in which the firm is viewed as setting a target debt-to-value ratio and gradually moving towards it, in much the same way that a firm adjusts dividends to move towards a target payout ratio.

2. An old-fashioned pecking order framework, in which the firm prefers internal to external financing, and debt to equity if it issues securities. In the pure pecking order theory, the firm has no well-defined target debt-to-value ratio.

Recent theoretical work has breathed new life into the pecking order framework. I will argue that this theory performs at least as well as the static tradeoff theory in explaining what we know about actual financing choices and their average impacts on stock prices. 
O autor propõe um novo caminho para as pesquisas na área em que os dois modelos já citados passem a ser comparados, tentando detectar como as empresas de capital aberto escolhem sua estrutura de capital. Então, há uma busca por um percentual ideal entre capital próprio e de terceiros que maximiza o valor de mercado da empresa? Ou a empresa sempre prefere se financiar com capital próprio, e no caso de busca de capital externo prioriza empréstimos sobre emissão de ações? Trabalhos teóricos na época tinham dado nova vida à POT. De acordo com o mesmo autor o desempenho da segunda teoria (POT) é no mínimo tão bom quanto o da STT.

O autor, Myers (1984, p. 579), explica que no caso da STT, os fatores que mais podem influenciar a determinação da meta são: os custos de ajustamento, que em geral são considerados baixos. Em seguida viriam as vantagens proporcionadas por taxas de impostos que criam um subsídio indireto ao endividamento. Nesse caso empresas com maiores taxas ganhariam mais e tenderiam a se endividar em percentuais maiores. Outro fator, talvez o mais importante na limitação do endividamento seria o custo de estresse financeiro. Levando-se em conta esse fator, empresas de menor risco se endividariam mais e empresas com mais ativos reais também.

Myers (1984, p.582) analisa a seguir o comportamento de empresas de capital aberto não financeiras no mercado norte-americano. $\mathrm{O}$ autor aponta evidências que apóiam a hipótese defendida pela POT. Por exemplo, entre 1973 e 1982, 62\% dos gastos em investimentos foram financiados por retenção de lucros. Nesse mesmo período somente $6 \%$ do financiamento externo proveio de emissão de ações.

As causas que poderiam levar as empresas a se comportar conforme a POT, ainda de acordo com o mesmo autor, são principalmente relacionados com assimetria de informações. O mercado, não tendo as informações que os administradores têm, subavalia as ações. No interesse dos atuais acionistas, ou mesmo no próprio interesse, os gestores preferem usar recursos de menor risco. Há toda uma literatura em finanças sobre esse tipo de assimetria de informação, parte da qual será discutida neste trabalho.

Os comportamentos das empresas observados na época do artigo, Myers (1984, p.585), os quais aparentemente permanecem atuais, são que (i) os gastos com investimento agregado são preferencialmente financiados com empréstimos e recursos gerados internamente. Esse fato pode ser explicado pela POT e também pela STT. (ii) As corporações 
geralmente escolhem momentos favoráveis para lançar ações, de acordo com vários estudos empíricos, após altas nos preços. (iii) As firmas que têm seu maior ativo em intangíveis ou oportunidades de investimentos futuros se endividam menos que as que possuem ativos reais. (iv) Os preços de ações geralmente sobem quando as empresas trocam financiamentos por elas e caem quando as emitem.

Na conclusão desse importante artigo o autor, Myers (1984, p. 589), mostra dúvidas quanto à aceitação pura e simples da POT. Sugere que as linhas de pesquisa poderiam tentar ajustar a STT para incorporar custos de ajustamentos, assimetria de informações e problemas de agência. Outra possibilidade seria partir da assimetria de informação e incorporar elementos da STT suportados por evidências. Depois de advertir o leitor para a fragilidade da teoria POT, o autor explica que, no entanto, ela é consistente com as evidências disponíveis.

Introduzindo um novo método Shyam-Sunder \& Myers (1999), usando duas equações simples procuraram verificar como as empresas cobriam seus déficits financeiros. Usando uma hierarquia de fontes, como previsto na POT ou procurando manter uma meta para o percentual de financiamento em relação ao capital próprio, como previsto na STT. Nesse artigo os autores mostraram que a POT explica muito melhor do que a STT o comportamento das empresas estudadas.

O mais interessante, de acordo com Shyam-Sunder \& Myers (1999, p. 242), é que simulando um banco de dados baseado no comportamento e nos valores das empresas reais, o modelo baseado na STT parece funcionar bem em qualquer caso, mesmo simulando um comportamento baseado na POT. Mas o comportamento previsto pela POT é facilmente rejeitado quando se simula o contrário. Com isso os autores mostraram que nem sempre os resultados que indicam que as empresas usam o STT são confiáveis.

Ainda no final do milênio, Fama \& French (2000) também discutem qual das teorias, POT ou STT explica melhor o comportamento das empresas. Nessa pesquisa eles examinaram mais de três mil empresas, em média, por um período de trinta e quatro anos. Os autores evitaram cometer alguns erros estatísticos que há em muitos trabalhos anteriores, como correlação entre resíduos etc. Eles procuraram verificar como a variação dos pagamentos de dividendos e da alavancagem se comportavam em relação à lucratividade e oportunidade de investimentos das empresas.

Para verificar se o comportamento dos dividendos pagos segue o modelo POT, Fama \& French (2000, p. 4) usam a previsão de Myers (1984) de que empresas com ativos 
permanentes menos lucrativos, grandes investimentos atuais e previstos, e alto endividamento em relação ao capital próprio pagariam menos dividendos. Então firmas mais rentáveis deveriam pagar mais dividendos, que seriam negativamente correlacionados com oportunidades de investimento e alavancagem. As previsões para pagamentos de dividendos na teoria STT são idênticas às da POT.

Quanto ao nível de endividamento em relação ao capital próprio, Fama and French (2000, p. 5), novamente usando as previsões de Myers (1984), testaram a hipótese da POT simples de que a alavancagem é menor para firmas mais rentáveis e, dada a rentabilidade, é maior para firmas com mais investimentos. Quanto a POT complexa a previsão é de que firmas com mais oportunidades de investimentos futuros sejam menos alavancadas. Já a STT prevê que firmas mais rentáveis sejam mais alavancadas financeiramente, sendo assim também para firmas com menos investimentos, com ganhos menos voláteis e menor fluxo de caixa.

As principais conclusões de Fama and French (2000, p. 30) são que (i) a previsão da POT de que firmas mais rentáveis são menos alavancadas se confirmou, contrariando a STT, (ii) as hipóteses compartilhadas pelas duas teorias também foram corroboradas, mas contrariando a POT, (iii) empresas de baixo crescimento e pouco alavancadas emitiram muitas ações no período estudado. Mas os autores afirmaram que nos casos em que as previsões compartilhadas se confirmaram não houve maneira de verificar se os resultados podem ser atribuídos a uma das duas teorias ou a outros fatores não estudados.

Lemmon and Zender (2002, p.31), usando o método proposto por Shyam-Sunder and Myers (1999) com adaptações, encontraram fortes evidências de que as empresas seguem a hierarquia de financiamento previsto pela POT. De acordo com os autores firmas de alta lucratividade e baixa alavancagem preferem financiar seu crescimento com fundos gerados internamente. Os autores observaram também que os custos de seleção adversa ajudam a explicar essa preferência.

Os autores também mostram que o comportamento de firmas novas e antigas é bem diferente. Por exemplo no período estudado, sempre de acordo com Lemmon \& Zender (2002, p. 11), as empresas mais novas, que são também as que têm maior crescimento nos ativos e maior déficit de fundos, financiaram $68 \%$ de seu déficit financeiro com emissões de ações, já as mais antigas cobriram $90 \%$ de suas necessidades de capital com emissão de títulos de dívida. Encontraram também evidências, no mesmo trabalho, que firmas mais lucrativas geralmente financiam seus investimentos com fundos gerados operacionalmente, de acordo 
com o previsto pela POT. Mesmo empresas que inicialmente têm baixa taxa de alavancagem, se têm boa rentabilidade, usam seus recursos internos para baixar ainda mais o nível de financiamento, contrariando a STT.

Esses autores aplicaram as regressões de Shyam-Sunder and Myers (1999) a diferentes subgrupos dentro da amostra de empresas estudadas. No caso de empresas com baixa alavancagem e pouca necessidade de financiamento externo, a regressão que mede o grau de ajuste à POT tem os índices quase iguais aos dos autores originais. Lemmon \& Zender (2002, p. 31) verificaram que empresas parecidas com as desse grupo, mas que têm alta alavancagem inicial, aparentemente se comportariam de maneira semelhante, mas verificando o baixo $\mathrm{R}$ quadrado e o intercepto da regressão, concluíram que nesse caso se financiariam com um mix de dívidas e ações.

Outro subgrupo de empresas que têm muita necessidade de capital externo, por causa do alto crescimento dos ativos e da baixa rentabilidade, geralmente empresas novas e em rápido crescimento, se financia preferencialmente com emissão de ações, o que também fica dentro das previsões da POT, de acordo com Lemmon \& Zender (2002, p. 31). Por outro lado, empresas com alta alavancagem, mas que necessitam de relativamente pouco financiamento externo, usam seus recursos gerados operacionalmente e emissão de ações para pagar suas dívidas. O comportamento nesse caso se aproxima do previsto na STT.

A importância do artigo de Lemmon \& Zender (2002) foi principalmente mostrar a importância de verificar se um determinado grupo de empresas tem ou não restrições a novos empréstimos, seu atual nível de alavancagem e previsão de crescimento, antes de tentar analisar seu comportamento financeiro.

Numa pesquisa de Mayer \& Sussman (2004, p. 1) sobre financiamento de grandes projetos em muitas empresas americanas os autores encontraram evidências de que a fonte de capital preferida é os empréstimos, o que de certa forma concorda com a POT. Mas, contrariando essa mesma teoria, os fundos gerados internamente não são a maior origem de recursos para esses investimentos. No mesmo artigo os autores também afirmam que as empresas tendem a manter uma alavancagem média constante, concordando com a "trade-off theory".

Os mesmos Mayer \& Sussman (2004, p. 25) explicam que há aspectos da "pecking order theory" que funcionam bem a curto-prazo, mas a longo-prazo prevalece a "trade-off 
theory". A infreqüência e menor importância de emissões de novas ações também foi negada pelos autores do artigo.

\subsection{Resultados de pesquisas anteriores sobre comparação entre POT E STT}

Após os artigos de Myers (1984) e Myers \& Majluf (1984), vários pesquisadores têm trabalhado na verificação da efetividade das teorias POT e STT, mas sem resultados conclusivos. Em muitas pesquisas as conclusões têm sido sobre uma possível nova teoria que aglutine aspectos válidos das duas abordagens e de outras. Muitas premissas relacionadas às duas teorias, como a assimetria de informações e os conflitos de agência, continuam a ser pesquisadas e têm confirmado, parcialmente, a sua validade.

Até 1998, a maioria dos trabalhos procurava evidências de uma ou outra teoria separadamente, procurando evidências de comportamento baseado na assimetria de informações para a POT ou de equilíbrio de custos e benefícios de endividamento para a STT. Também havia pesquisas sobre os fatores que levavam a um nível determinado de endividamento ou que explicassem porque as empresas preferiam usar fontes internas e dívidas em vez de ações.

$\mathrm{Na}$ bibliografia pesquisada para esta dissertação, o primeiro trabalho que fez a comparação empírica entre as duas teorias foi o de Shyam-Sunder and Myers (1999), que procuraram verificar como as empresas cobriam seus déficits financeiros. Usando uma hierarquia de fontes, como previsto na POT ou procurando manter uma meta para o percentual de financiamento em relação ao capital próprio, como previsto na STT. A conclusão dos autores foi que a POT explica muito melhor do que a STT o comportamento das empresas estudadas.

As variáveis usadas por Shyam-Sunder and Myers (1999) foram o Déficit (DEF) de cada período "t" para cada empresa "i”, calculado somando o pagamento de dividendos (DIV), os gastos de capitais $(\mathrm{X})$, a variação do capital de giro $(\Delta \mathrm{W})$ e a parcela de vencimento corrente das dívidas de longo prazo $(\mathrm{R})$ e subtraindo o fluxo de caixa operacional após juros e impostos (C). Os autores então montaram uma regressão em que a variável dependente era a variação nos empréstimos em cada período (D) e a independente os déficits (DEF).

A novidade principal do artigo de Shyam-Sunder and Myers (1999) foi que os autores não usaram fatores para provar indiretamente as teorias, mas verificaram como os débitos decorrentes do pagamento de novos investimentos e dividendos eram cobertos, ano a ano. A 
conclusão, como já dito, foi que depois de usar os fundos gerados internamente o uso de empréstimos supera largamente a emissão de ações.

Em crítica ao método de Shyam-Sunder and Myers (1999), Chirinko \& Singha (2000) mostraram que podem ocorrer situações em que a equação usada por aqueles autores aponta falsamente para resultados que não correspondem à realidade. Eles apontam três tipos de problemas principais. No primeiro caso, os autores deram exemplo de uma empresa que apesar de dar preferência aos empréstimos depois de usar fundos internos, mesmo assim busca em torno de $22 \%$ de suas necessidades de capital em ações. Nesse caso a equação aponta falsamente para a STT, sendo que a empresa ainda usa a hierarquia prevista na POT semiforte.

No segundo caso, Chirinko \& Singha (2000) mostram que uma empresa usando em primeiro lugar emitir ações e só posteriormente buscando empréstimos também pode ser considerada falsamente como obedecendo a POT. E no terceiro e último exemplo os mesmos autores mostram que mesmo que a empresa sempre emita ações e títulos de débito em proporções fixas (embora usando mais empréstimos do que ações) a equações dará resultado favorável a POT, sendo que esse tipo de procedimento demonstra a tentativa da firma de manter uma meta fixa de empréstimos como previsto na STT.

Apesar do acerto da crítica de Chirinko \& Singha (2000), nesta dissertação será utilizado o método de Shyam-Sunder and Myers (1999) com as adaptações mostradas na metodologia do trabalho, tomando-se os cuidados necessários para verificar se há algum dos fatores mostrados por aquels autores que esteja deturpando os resultados.

Fama \& French (2000) também compararam as duas teorias, verificando a questão da alavancagem financeira e pagamento de dividendos. Nessa pesquisa usaram fatores como tamanho, lucratividade, oportunidade de investimento e outros os autores não conseguiram concluir a favor de nenhuma das duas teorias. Muitos fatores com previsões compartilhadas pelos dois modelos foram confirmados. Nas previsões não comuns a correlação negativa entre lucratividade e nível de endividamento favoreceu a POT.

Frank \& Goyal (2002) estudando um grande número de empresas americanas descobriram que os financiamentos externos e emissões de ações entre 1971 e 1998 ficaram bem acima do aceito pela Pecking Order Theory (POT). O grande afluxo de empresas menores ao mercado aberto, durante os anos 80 , mas principalmente nos anos 90 , influenciou muito o resultado alcançado por Frank \& Goyal (2002), já que essas empresas emitem muito mais ações do que as grandes e maduras. 
A principal novidade do trabalho de Lemmon \& Zender (2002, p.7) foi que, para usar a equação de Shyam-Sunder and Myers (1999), os autores selecionaram as empresas de acordo com a "capacidade de assumir débitos" (debt capacity). De acordo com os autores essa capacidade é uma premissa importante definida por Myers (1977) como o ponto em que ao emitir mais títulos de débito a empresa diminui seu valor de mercado. Os autores mostraram que o comportamento de firmas novas, de grande crescimento é diferente de empresas maduras. As primeiras geralmente têm menos geração de fundos internos e portanto maiores déficits e muitas vezes preferem se financiar com emissão de ações. Essa diferença, que autores como Frank \& Goyal (2002) apontam como contrária a POT, na verdade está prevista na teoria.

Os resultados obtidos por Lemmon \& Zender (2002) foram que firmas com mais oportunidades de crescimento (alto valor de mercado em relação ao de livro), usam menos empréstimos e firmas com mais ativos tangíveis usam mais. Empresas mais antigas também têm um nível de alavancagem financeira um pouco maior do que as mais novas. Os autores também encontraram correlação negativa entre lucratividade e nível de endividamento, corroborando a previsão da POT. A conclusão de Lemmon \& Zender (2002) foi favorável a POT, nas próprias palavras dos autores:

Our results illustrate that there is a pecking order for the sources of finance that places internally generated funds at the top, followed by debt for firms that are not constrained by their debt capacity. The fact that highly profitable, low leverage firms use internally generated financing to fund their growth and allow their leverage ratios to drop is inconsistent with the static tradeoff theory.

No Brasil, Medeiros e Daher (2004) reproduziram, parcialmente, a pesquisa de Shyam-Sunder \& Myers (1999), para testar se as empresas brasileiras de capital aberto têm o comportamento financeiro parecido com as estudadas pelos autores americanos. Os autores brasileiros fizeram duas modificações principais no modelo original. Em primeiro lugar, para testar o déficit das empresas não levaram em conta o montante de empréstimos de longo prazo pago no período, conforme modificação proposta por Frank \& Goyal (2002). Em segundo lugar, não usaram a equação dos autores originais para verificar a conformidade com a STT e sim o modelo proposto por Rajan and Zingales (1995).

O resultado do teste de Medeiros e Daher (2004) aplicado a 371 empresas não financeiras brasileiras, entre os anos de 1995 até 2002, foi muito parecido com o da pesquisa original, mostrando que essas empresas se adaptam melhor ao modelo conhecido como 
Pecking Order Theory. No teste usado para a STT, tanto o nível dos ativos tangíveis como o da lucratividade se mostraram negativamente relacionados com o endividamento, ao contrário do previsto pela teoria e de acordo com a POT. No teste para testar a Pecking Order Theory o coeficiente para verificar se os déficits financeiros eram cobertos por empréstimos ficou próximo da unidade, comprovando que as empresas quase não recorreram a emissões de ações, também corroborando a POT.

Também no Brasil, Silva e Brito (2004) testando as previsões das teorias Pecking Order e Static Tradeoff para endividamento e pagamento de dividendos, chegaram à mesma conclusão de Medeiros e Daher (2004). Isto é, as empresas mais lucrativas e menos endividadas distribuem mais dividendos, os dividendos não sofrem variações de curto prazo para permitir investimentos e, ainda, as empresas mais lucrativas são menos endividadas. Todas as conclusões favorecendo a interpretação dada pela POT.

Fama \& French (2005) encontraram evidências de que as emissões de ações pelas firmas de capital aberto nos Estados Unidos estão em desacordo com a Pecking Order Theory. Os autores sugerem que alguns tipos de emissões, como as opções para trabalhadores da própria empresa, não têm os custos de assimetria de informação que justificam a POT. Embora o artigo conclua pela não existência da hierarquia de fontes prevista pela POT, eles também não encontram evidências favoráveis a Static Tradeoff Theory, entre outros motivos, pela correlação negativa entre lucratividade e alavancagem financeira.

Outra pesquisa que mostrou haver uma meta para o endividamento, favorecendo a STT, foi a de Flannery \& Rangan (2004). Nesse trabalho os autores encontraram evidências de que há um ajustamento relativamente rápido quando as empresas desviam de seus níveis de endividamento ideais.

Frank \& Goyal (2007, p. 32), estudando fatores que consideram realmente importantes para definir a estrutura de capital, encontraram evidências que favorecem em parte a POT, como a tendência de que empresas com mais lucratividade tenham menor alavancagem. Mas também mostraram tendências favoráveis a STT, como o tamanho relacionado positivamente com o endividamento e a tendência da empresa particular de ter uma meta de alavancagem próxima da do setor industrial em que atua.

Em outro trabalho de Frank \& Goyal (2007), em que mais uma vez são comparadas as teorias STT e POT, os autores chamam mais uma vez a atenção para a importância de verificar que tipo de empresa está sendo estudado. Mostram a grande diferença entre o comportamento de grandes empresas (corporações) e firmas menores que têm papéis no mercado aberto. As grandes empresas de capital aberto tendem a reter ganhos (financiamento 
interno) e emitir debêntures (bonds). Já as empresas menores de capital aberto costumam usar muito a emissão de ações.

Nessa pesquisa revisando grande parte da literatura sobre as teorias citadas, Frank \& Goyal (2007, p.59) concluem que, apesar da predominância da STT, não há uma teoria que explique totalmente o comportamento financeiro das empresas. De acordo com os autores, muitos dos problemas apontados para a aceitação da STT foram explicados pela abordagem dinâmica do problema (Dinamic Tradeoff Theory), que leva em consideração as mudanças constantes no ambiente e na própria empresa. Mas permanecem outros problemas que também não dão validade a STT.

Os mesmos Frank \& Goyal (2007), também apontam problemas mais sérios na POT, como o fato de que empresas que têm caixa suficiente para cobrir os investimentos também emitem títulos de dívidas. Ou ainda, firmas que emitem ações quando, de acordo com a mesma teoria, não deveriam fazê-lo.

A verdade, ainda de acordo com Frank \& Goyal (2007, p. 60), é que há muitas falhas nas duas abordagens, tanto a POT como a STT não explicam totalmente o comportamento das empresas pesquisadas nas últimas décadas, principalmente nos Estados Unidos. Há pesquisas em curso para tentar criar uma teoria unificada que explique muitos fatos estilizados que nenhuma das teorias em vigor esclarecem totalmente.

Finalizando essa revisão bibliográfica, pode-se concluir que não existe um modelo teórico que explique o comportamento das empresas no aspecto financeiro. Ultimamente, a teoria que tem dominado mais as discussões é a Static Tradeoff Theory, que, de acordo com vários autores já citados, explicaria melhor o comportamento das empresas nas últimas décadas. A Pecking Order Theory, que também explica alguns aspectos das finanças empresariais, tem sofrido muitos revezes nos últimos anos, principalmente devido a verificação de que as empresas americanas não têm seguido sua hierarquia de fontes, conforme explicado anteriormente.

No Brasil, principalmente baseado na pesquisa de Medeiros e Daher (2004), que usou métodos similares ao desta dissertação, a POT tem sido aceita como a melhor explicação para o comportamento das empresas não financeiras de capital aberto. 


\section{METODOLOGIA}

Esta é uma pesquisa descritiva, porque descreve características do objeto de estudo e verifica relações entre variáveis. Quanto à abordagem, é uma pesquisa quantitativa, tendo em vista que são analisados números contábeis e de mercado divulgados pelas empresas, com a finalidade de estabelecer relações entre eles e verificar sua conformidade ou não com as teorias investigadas através de modelos matemáticos. Há alguns aspectos qualitativos, principalmente quando os resultados são interpretados à luz das teorias e da realidade do país.

Os dados utilizados, de natureza secundária, foram obtidos na base de dados Economática®, oriundos dos Balanços Patrimoniais, das Demonstrações de Resultado, das Demonstrações de Origens e Aplicações de Recursos e das Demonstrações de Fluxos de Caixa. Todos os dados são de empresas brasileiras não financeiras de capital aberto listadas na BM\&FBOVESPA.

Os números usados foram os consolidados ou, quando inexistentes, os da controladora. O período analisado vai do ano 2000 até junho de 2010. Com exceção dos dados de 2010, que foram os de junho, todos os outros foram do fechamento das demonstrações em dezembro. $\mathrm{O}$ motivo para o uso dos dados do final de ano foi a completude das informações nestas datas.

Antes da abordagem empírica do problema, efetuou-se uma ampla pesquisa bibliográfica em livros, artigos e outras publicações nacionais e, principalmente, internacionais. Os principais pontos dessa pesquisa bibliográfica estão descritos na revisão bibliográfica deste trabalho, no capítulo dois.

A metodologia aplicada neste trabalho para testar empiricamente a Peking Order Theory (POT) é baseada principalmente no modelo utilizado por Shyam-Sunder \& Myers (1999), adaptada por Frank \& Goyal (2002). Para testar a Static Trade-off Theory (STT) foi aplicada a regressão utilizada originalmente por Rajan \& Zingales (1995). Os mesmos modelos foram utilizados por Medeiros e Daher (2008), para o período de 1995 até 2002, no Brasil.

O modelo original de Shyam-Sunder \& Myers (1999, p. 224) usa as seguintes variáveis, sempre para o período "t" e para as empresas "i”: DEF, que é o déficit de fundos para cada empresa; DIV, que é o pagamento de dividendos no período; X, que significa gastos de capitais fixos; $\Delta \mathrm{W}$, que representa a variação de capital de giro no período; $\mathrm{R}$, que é a parcela de vencimento corrente das dívidas de longo prazo e $\mathrm{C}$ que representa o fluxo de caixa operacional do período. Então, a fórmula usada para calcular o déficit é a seguinte: 


$$
D E F_{t}=D I V_{t}+X_{t}+\Delta W_{t}+R_{t}-C_{t}
$$

Portanto, o déficit (que também pode ser superávit) do período é calculado somando os valores dispendidos com pagamento de dividendos, com gastos de capital e de capital de giro, com pagamentos de dívidas de longo prazo vencidas no período e subtraindo desse total o fluxo de caixa operacional. Esse é o valor que a empresa deve financiar com empréstimos ou emissão de ações, de acordo com os autores em pauta.

A partir daí os autores montam uma regressão usando as seguintes variáveis, também para as empresas "i" e períodos "t": $\Delta \mathrm{D}$, que é a variável dependente e representa a variação dos empréstimos no período, podendo ser negativa ou positiva; "a", que é o intercepto da regressão; "bpo", que é o coeficiente da variável dependente e "e", o erro da regressão. A variável dependente é o DEF, calculado na fórmula dois. O modelo a ser testado fíca conforme mostrado na equação abaixo:

$$
\Delta D_{i t}=a+b_{p o} D E F_{i t}+e_{i t}
$$

De acordo com os mesmos autores, a tendência na regressão representada na fórmula três é que, se a hipótese da pecking order theory estiver correta, o intercepto "a" se aproxime de zero e "bpo", que é chamado pelos autores de coeficiente pecking order, se aproxime da unidade. o raciocínio é que, se as empresas não usarem emissão de ações, as variações nas dívidas serão iguais às variações nos déficits dos períodos.

Frank \& Goyal (2002, p.6) fazem a seguinte modificação na fórmula dois: retiram o termo R, que é a parcela de vencimento corrente das dívidas de longo prazo, mantendo as outras variáveis, sendo que a fórmula para cálculo do déficit financeiro fica assim:

$$
D E F_{t}=D I V_{t}+I_{t}+\Delta W_{t}-C_{t}
$$

Observe-se que Frank \& Goyal (2002) nomeiam a variação nos investimentos fixos de "I" e não "X", como os autores originais. Os autores justificaram a retirada da variável "R" explicando que usaram a definição contábil de déficit e que, testando as duas abordagens, essa parcela não fez muita diferença nos resultados, a não ser favorecendo a interpretação favorável a POT.

Quanto à regressão representada na fórmula três, Frank \& Goyal (2002) usaram-na sem nenhuma modificação, também entendendo que os coeficientes "a" e "bpo" deveriam se aproximar de zero e de um respectivamente. 
Nesta dissertação há uma modificação para o modelo de Frank \& Goyal (2002), adaptado de Shyam-Sunder \& Myers (1999), que testa a POT. Consiste na introdução dos termos "outras fontes não financeiras" e "outras aplicações não financeiras" na medida do déficit do período. O termo "não financeiro" serve para esclarecer que os recursos não são provenientes de empréstimos nem de emissão de ações. Esta modificação não modifica o objetivo da pesquisa, que é o mesmo dos trabalhos originais, isto é, verificar se o déficit é coberto por dívidas ou por emissão de ações. As modificações são mostradas na equação cinco apresentada na continuação da metodologia.

A seguir, são mostradas as variáveis que foram utilizadas para testar cada uma das hipóteses previstas pelas teorias estudadas, todas medidas pelos períodos de tempo " $\mathrm{t}$ " para empresas "i":

Tabela 1: Descrições das variáveis a serem testadas em cada modelo

\begin{tabular}{|c|c|c|c|}
\hline \multicolumn{2}{|c|}{ Pecking Order Theory } & \multicolumn{2}{|c|}{ Static Trade-off Theory } \\
\hline Variáveis & Descrição & Variáveis & Descrição \\
\hline Def & Déficit do Período & $\mathrm{D}$ & Empréstimos / Capital Próprio \\
\hline Div & Dividendos pagos no período & & (Alavancagem) \\
\hline Inv & Investimentos líquidos (fixos) & $\mathrm{T}$ & Imobilizado / Permanente \\
\hline $\mathrm{Cg}$ & Variação no Capital de Giro & & (proxy para tangibilidade) \\
\hline $\mathrm{Oa}$ & Outras Aplicações não & MBV & Valor de Mercado/Valor \\
\hline & financeiras & & contábil (Proxy para \\
\hline $\mathrm{Fc}$ & Fluxo de Caixa do período & & capacidade de crescimento) \\
\hline Of & Outras fontes não financeiras & LS & Logaritmo das Vendas (Proxy \\
\hline $\mathrm{E}$ & Variação nos Empréstimos de & & para tamanho da empresa) \\
\hline & determinado período & LCR & Lucro / PL (lucratividade) \\
\hline
\end{tabular}

\subsection{Metodologia de teste para a POT}

Com os dados das demonstrações financeiras de empresas brasileiras de capital aberto, exceto as financeiras, foram obtidos os valores de pagamento de dividendos (Div), investimentos em capital fixo (Inv), variação em capital de giro $(\mathrm{Cg})$, outras aplicações não financeiras $(\mathrm{Oa})$, fluxo de caixa operacional $(\mathrm{Fc})$ e outras fontes não financeiras $(\mathrm{Of})$. Então, o déficit de fundos a ser financiado a cada ano foi medido por: 


$$
D e f=D i v+I n v+C g+O a-O f-F c
$$

Conforme já explicado, a equação acima é uma modificação para este trabalho da fórmula de Frank \& Goyal (2002), que, por sua vez, é uma adaptação da equação original de Shyam-Sunder \& Myers (1999). A diferença da fórmula acima para a de Frank \& Goyal (2002), é que na deles não entravam os termos outras aplicações não financeiras (Oa) e outras fontes não financeiras (Of).

Para dar um exemplo da diferença entre o uso da fórmula 5 e da fórmula 4 de Frank e Goyal (2002), suponha-se que uma empresa receba um grande valor contabilizado como não operacional. Se for usada a regressão mostrada neste trabalho (fórmula 3), no período em questão o déficit operacional, supondo que haja, não estará sendo coberto por novas dívidas e parecerá que houve emissão de ações. Usando o déficit total, conforme a fórmula 5, a interpretação será a correta.

Portanto, como a fórmula 5, mostrada anteriormente, contempla todos as fontes e aplicações não financeiras do período, o déficit (ou superávit) terá que ser financiado com emissão de dívidas (incluindo debêntures) ou de ações.

Em parte deste trabalho optou-se pelo uso da variação total dos empréstimos, de curto e longo prazo, porque em parte da pesquisa (que não usa a DOAR) a variável dependente é a soma de empréstimos e debêntures de longo e curto prazo. No resultado final o déficit fica igual nos dois casos porque, em caso de uso só de empréstimos de longo prazo, as variações nas dívidas de curto prazo passam a fazer parte da variação no capital de giro das empresas.

A hipótese a ser testada, pecking order Theory (POT), é de que a empresa quase nunca usará o financiamento por emissão de capital. Então, medindo o montante de empréstimos assumidos no período (E), foi testada a regressão linear usada originalmente por ShyamSunder \& Myers (1999), que é a fórmula 3 já mostrada anteriormente. Onde, espera-se que se a hipótese for correta, a variável 'a' tenderá a zero, ou será estatisticamente insignificante, e 'bpo' será aproximadamente igual a um. Conforme observaram os autores originais, o valor de emissões e recompras de ações não estão contempladas na variável 'Def ' e, portanto, a fórmula 3 não é uma igualdade contábil.

A principal diferença desta pesquisa em relação à de Shyam-Sunder \& Myers (1999), que testa a POT, é que o déficit utilizado não foi, como na pesquisa original, obtido da diferença entre fluxo operacional e necessidades de investimentos e pagamento de dividendos. 
Mas foi um déficit total, obtido após a soma de todas as fontes e a subtração de todas as aplicações.

Observe-se também que o que é chamado de déficit nesta pesquisa, não é sempre uma deficiência de fundos, podendo ser e sendo muitas vezes uma sobra de recursos que podem servir para pagar empréstimos ou recomprar ações. A mesma observação vale para a variável dependente (E), que pode ser um fluxo positivo (novos empréstimos) ou negativo (pagamento de empréstimos).

Para ajudar a verificar o comportamento financeiro das empresas sob o ponto de vista da POT, foi elaborada uma tabela e traçado um gráfico em que são comparadas ano a ano as fontes de financiamento das firmas, divididas em caixa operacional, empréstimos e ações.

A seleção das empresas a serem analisadas para a POT foi a seguinte: em primeiro lugar, buscou-se no banco de dados Economática ${ }^{\circledR}$ todas as empresas que tinham ações na BM\&FBOVESPA. O segundo passo foi eliminar aquelas do ramo financeiro e de seguros. Daí em diante, para testar a POT, utilizando-se as fórmulas 3 e 5 , foram eliminadas as empresas que não tinham os dados necessários e as que abriram o capital no ano.

A razão de não usar na amostra as empresas que abriram o capital no ano é a finalidade do teste. O objetivo da regressão usada é verificar se as empresas, depois de usar o caixa operacional, preferem emitir ações ou buscar capital de terceiros. No caso de abertura de capital não há opção, a empresa obrigatoriamente emite ações. Portanto, como não há escolha por parte dessas entidades, elas não devem entrar na amostra.

Com a amostra de empresas selecionadas para medir a adequação ao modelo proposto pela POT (equações 3 e 5), os procedimentos se dividiram em dois tipos diferentes. $\mathrm{O}$ primeiro tipo foi nos anos em que as empresas publicaram fluxos de caixa, isto é, em 2008, 2009 e junho de 2010. O segundo foi em todos os outros anos em que os dados foram tirados do demonstrativo chamado DOAR (Demonstração de Origem e Aplicação dos Recursos). A razão de usar dois procedimentos diferentes é que no Brasil quando as empresas eram obrigadas a publicar a DOAR não se publicava o Demonstrativo de Fluxo de Caixa, e viceversa.

Nos anos em que se publicaram os fluxos de caixa os dados utilizados foram o caixa gerado por investimentos (i), dividendos pagos (ii), variação líquida de caixa (iii), caixa gerado por operações (iv), efeito cambial (v) e caixa gerado (aplicado) por outros financiamentos (vi). O déficit (superávit) foi calculado somando os itens i, ii, iii, e subtraindo 
os itens iv, v e vi. A fórmula seria: Def $=\mathrm{i}+\mathrm{ii}+\mathrm{iii}-\mathrm{iv}-\mathrm{v}-\mathrm{vi}$, que corresponde à fórmula 5 anterior.

Além dessas variáveis independentes, foram obtidos os financiamentos líquidos obtidos e os aumentos líquidos de capital. A variável dependente em todas as regressões foi o total dos financiamentos líquidos obtidos. Os aumentos líquidos de capital serviram para traçar o gráfico de financiamento das empresas. A consistência do modelo foi verificada somando os financiamentos e os aumentos de capital, o total da soma sempre tinha que ser igual ao déficit financeiro do período, como explicado anteriormente.

Naqueles períodos em que não foram publicados fluxos de caixa, para calcular as fontes foram obtidos os seguintes valores (usando a nomenclatura da base de dados utilizada): Das Operações, Venda/Baixas Bens Permanentes, Dividendos Recebidos, Incentivos Fiscais, Aumento do Passivo LP, Redução do Realizável LP, Cap Circ Incor Cont / Colig, Aumento de Ações Tesouraria e Outras Origens.

As aplicações foram: Aplicação no Ativo Permanente, Aumento do Realizável LP, Diminuição no passivo LP, Dividendos, Transf do Circ p / Permanente, Adiantamento para Compra de Ações, Aquisição de Ações Próprias, Controladas/Incorporadas, Incorporações, Participações Minoritárias, Outros Recursos Aplicados e Aumento no Capital de Giro.

Os déficits (superávits) desses anos, em que no Brasil não se publicava a "Demonstração do Fluxo de Caixa", foram obtidos somando as fontes (origens) e subtraindo as aplicações discriminadas nos dois parágrafos anteriores.

Para concluir esta parte do trabalho relativa a POT, usando a regressão representada na fórmula 3, cada variação nos empréstimos serviu de variável dependente para os déficits de cada empresa.Depois, foi verificada a estatística teste e os pressupostos de cada regressão foram analisados. Os resultados estão descritos no capítulo quatro desta dissertação.

O principal indicador da validade das regressões é a correlação entre as variáveis e o R quadrado (coeficiente de determinação) que indica a porcentagem da variação explicada pela variável independente. Nesta dissertação sempre foi usado o R quadrado ajustado que corrige distorções provocadas pela inclusão de mais de uma variável independente e pelo tamanho da amostra, conforme Corrar et al. (2007, p. 150).

Foi utilizado o teste F-ANOVA para verificar a hipótese de que o R quadrado é maior do que zero e o teste $t$ de Student para medir a significância dos coeficientes das regressões. Para medir a adequação das regressões aos pressupostos necessários à validação dos resultados foram feitos os testes de Kolmogorov-Smirnov para a normalidade dos resíduos, 
Pesarán-Pesarán para a homoscedatiscidade, Durbin-Watson para a ausência de autocorrelação serial e o teste VIF (Variance Inflation Factor) para a multicolinearidade.

$\mathrm{Na}$ análise dos testes acima, de acordo com Corrar et al. (2007), espera-se que as significâncias dos testes $\mathrm{F}$ e t, sejam menores do que $\alpha$, no caso deste trabalho 0,01 (um por cento). No teste de normalidade espera-se que a significância seja maior do que 0,01. Para a homoscedasticidade, usando Pesarán-Pesarán, a significância também tem que ser maior do que 0,01. Na medida de ausência de autocorrelação o índice Durbin-Watson deve estar próximo de 2 e no teste de multicolinearidade o VIF deve estar entre 1 e 10.

Para confirmar os resultados obtidos, todos os procedimentos citados, desde a seleção das empresas até a obtenção dos dados, foram repetidos em três datas distintas, em 14/08/2010, em 29/10/2010 e em 21/12/2010. O motivo para a repetição da colheita de dados e análise foi verificar e eliminar possíveis erros na seleção das empresas e na aplicação dos testes estatísticos.

\subsection{Metodologia de teste para a STT}

Na segunda parte do trabalho empírico, em que é testado o modelo conhecido como “Static Tradeoff Theory" (STT), foi usada a regressão abaixo, conforme modelo proposto por Rajan \& Zingales (1995):

$$
D_{i t}=\alpha+\beta_{T} T_{i t}+\beta_{M B V} M B V_{i t}+\beta_{L S} L S_{i t}+\beta_{L C R} L C R_{i t}+\varepsilon_{i t}
$$

Onde Dit é o total de endividamento no período "t" pela empresa "i”, os índices $\alpha$ e $\beta$ são os coeficientes da regressão, $\varepsilon$ é o erro do período, $\mathrm{T}$ é a tangibilidade dos ativos, representada por imobilizado / permanente, MBV é o índice resultante da divisão valor de mercado / valor patrimonial, LS é o logaritmo natural das vendas (Ln (Faturamento)) e LCR a lucratividade, representada por Lucro Líquido / Patrimônio Líquido.

Conforme Myers (1984), Long \& Malitz (1985), Harris \& Raviv (1990a), Frank \& Goyal (2002) e outros, espera-se que as empresas com ativos mais tangíveis se endividem mais, então a tendência é que o coeficiente de T seja positivo. Os próprios Harris \& Raviv (1990a) escrevem: "Thus, the model predicts that firms with higher liquidation value, e.g., those with tangible assets, will have more debt..."

O problema é que os mesmos Harris \& Raviv (1991) prevêem um comportamento diferente para o caso de serem verdadeiras as hipóteses da POT, explicam que empresas com menos ativos tangíveis provavelmente terão mais problemas de assimetria de informação. 
Então, para diminuir esses problemas acumulariam mais dívidas. Mas a maioria dos autores prevê uma relação positiva entre endividamento e tangibilidade para as duas teorias. Nesta dissertação o sinal esperado para a tangibilidade será positivo para as duas teorias.

Conforme Myers (1984), Rajan \& Zingales (1995), Fama \& French (2000), o índice que mede o valor de mercado em relação ao contábil (MBV) é negativamente relacionado ao endividamento. Essas empresas geralmente têm grandes oportunidades de crescimento e muitos intangíveis, que não servem de garantia colateral para débitos. Então, nesta dissertação, espera-se um índice negativo para o coeficiente de MBV.

Conforme Frank \& Goyal (2007), Harris \& Raviv (1991), Strebulaev (2007) o tamanho das empresas é positivamente relacionado com a alavancagem. Portanto, o coeficiente de LS, que é usado para proxy de tamanho das empresas, tende a ser positivo, porque quanto maior a empresa espera-se, de acordo com a STT e com a POT, um maior endividamento. $\mathrm{O}$ índice esperado para o coeficiente tamanho é, portanto, positivo.

Myers (1984), Titman \& Wessels (1988) e Fama \& French (2000) previram uma menor alavancagem para firmas mais lucrativas. Então a lucratividade, medida por LCR, de acordo com a POT (ao contrário da STT), deve ter um índice negativo, porque essa teoria prevê menor endividamento para empresas mais lucrativas. Como o teste aplicado nessa parte do trabalho é para verificar a adequação a STT o índice esperado é positivo.

Então, os coeficientes esperados, no caso da STT, são positivos para a tangibilidade (T), negativos para a oportunidade de crescimento (MBV), positivos para tamanho (LS) e positivos para a lucratividade (LCR). Esses sinais esperados para os coeficientes são os mesmos do trabalho de Frank \& Goyal (2002) e de Medeiros e Daher (2004), com a diferença de que Frank \& Goyal (2002) testavam a POT e aqui é testada a STT com a regressão em pauta, portanto eles esperavam sinal negativo para a lucratividade e aqui se espera sinal positivo.

Outro ponto a ser destacado em relação ao teste para a STT, é sobre o que é chamado de "alavancagem" neste trabalho. O termo é usado por analogia com a palavra inglesa "leverage" e não tem relação com os usos mais comuns em finanças, significando, no caso desta dissertação, o total de empréstimos em relação com o capital próprio (empréstimos + debêntures / PL). Em finanças, há a alavancagem operacional e a financeira, significando, de maneira simplificada, no primeiro caso o quanto aumentam os lucros quando há aumento de receita e no segundo caso o quanto aumenta a lucratividade com o uso de empréstimos.

A alavancagem neste caso pode ser medida de diferentes maneiras, a principal usada neste trabalho foi o valor do total de empréstimos de curto e longo prazo, somado às 
debêntures, dividido pelo capital próprio (PL). Uma segunda maneira usada foi dividindo o total de empréstimos e debêntures pelo capital total (próprio mais de terceiros). Calculou-se também dividindo o mesmo total pela soma dos ativos totais. As duas últimas maneiras de medir a alavancagem só foram usadas neste trabalho em gráficos e tabelas.

Outra maneira de medir as variáveis utilizadas seria pelo valor de mercado, com o valor de mercado da empresa dos empréstimos etc. No caso desta pesquisa, principalmente por se tratar de dissertação na área de ciências contábeis, quase todas as variáveis utilizadas foram com valor contábil. A única exceção foi o valor de mercado utilizado na variável independente MBV (valor de mercado/valor contábil).

Além da regressão usada para analisar os dados das empresas foram incluídos alguns gráficos e tabelas para ajudar a visualizar a situação. Os gráficos que tentam verificar se as empresas mantêm alguma estabilidade no total de endividamento em relação ao capital próprio, capital total e ativo total.

A maneira de selecionar as empresas a serem analisadas foi a seguinte: em primeiro lugar, buscou-se no banco de dados Economática ${ }^{\circledR}$ todas as empresas que tinham ações na BM\&FBOVESPA. O segundo passo foi eliminar aquelas do ramo financeiro e de seguros. $\mathrm{O}$ terceiro procedimento para testar a STT, usando a fórmula 7, foi eliminar também as empresas com o PL (patrimônio líquido) negativo. Porque, caso contrário, haveria alavancagens negativas, o que se explica por causa do denominador da alavancagem, neste trabalho, ser o PL. Na verdade, não pode haver alavancagem (no sentido explicado anteriormente) negativa. Ou a empresa tem empréstimos e o índice é positivo ou não tem e a alavancagem é igual a zero.

Depois das eliminações acima, para testar a STT, foram colhidos, ano a ano, os seguintes dados: ativo permanente, imobilizado, índice relativo ao preço de mercado dividido pelo valor contábil da empresa, receita bruta, rentabilidade sobre o PL, patrimônio líquido, ativo total, empréstimos de curto prazo, empréstimos de longo prazo, debêntures de curto prazo, debêntures de longo prazo. Os índices representando a dívida total sobre o PL e sobre os ativos totais também foram calculados. O índice da dívida total sobre capital total foi calculado dividindo o total de empréstimos pela soma do PL com as próprias dívidas. 
O passo seguinte foi calcular o índice de imobilização dividindo o imobilizado pelo permanente de cada empresa e a cada ano. A outra transformação necessária foi calcular os logaritmos neperianos ${ }^{\bullet}$ das receitas brutas, para representar o tamanho das empresas.

Depois foram efetuadas, para todas as empresas e a cada ano, as regressões múltiplas representadas na fórmula 7. Essas regressões, cujas variáveis independentes foram a imobilização, o logaritmo das vendas, o índice valor de mercado sobre valor contábil e a rentabilidade, tiveram como variável dependente o índice representativo da alavancagem.

Os testes utilizados para validar as regressões foram os mesmos aplicados na estatística da POT, conforme descritos anteriormente neste trabalho. Os Resultados das regressões e dos testes aplicados estão descritos no capítulo quatro desta dissertação.

Conforme explicado anteriormente para os testes da POT, também no caso da STT os procedimentos foram todos repetidos em três datas distintas, em 14/08/2010 e em 29/10/2010 e 21/12/2010. O motivo para tal a repetição dos testes foi o mesmo explicado anteriormente para a POT.

\footnotetext{
- $\mathrm{O}$ uso de logaritmos se justifica tendo em vista que o crescimento das receitas entre empresas é muito grande. O logaritmo possibilita a transformação dessa evolução exponencial em linear, permitindo verificar a influência do tamanho na alavancagem. Rajan \& Zingales (1995), Frank \& Goyal (2002) e Medeiro e Daher (2008) também usaram logaritmos naturais.
} 


\section{RESULTADOS DA PESQUISA}

A pesquisa empírica foi dividida em duas partes. $\mathrm{Na}$ primeira foram analisados as variáveis independentes (fatores): lucratividade (LCR), representada por Lucro Líquido/Patrimônio Líquido, expectativa de crescimento (MBV), cujo proxy é valor de mercado/valor contábil da empresa, tamanho da empresa (LS), que é o logaritmo natural do faturamento bruto e tangibilidade dos ativos (T), medida por ativo imobilizado/permanente. A variável dependente das regressões múltiplas foi $\mathrm{o}$ endividamento das empresas (alavancagem), representado por empréstimos + debêntures divididos por PL.

$\mathrm{Na}$ segunda parte foram feitas regressões simples, também ano a ano, em que os déficits ou superávits totais das empresas foram relacionados com a variação no total de empréstimos das empresas. No caso os déficits (Def), calculados conforme explicado no capítulo sobre a metodologia, foram as variáveis independentes e as variações nos empréstimos $(\Delta \mathrm{D})$ as variáveis dependentes.

Os objetivos, conforme já explicado anteriormente, foram dois. Em primeiro lugar, verificar se há relacionamento entre os fatores e o endividamento que concordem com a teoria de meta de alavancagem conhecida como Static Tradeoff Theory (STT). Em segundo lugar, analisar, por meio de regressões, se as empresas seguem a ordem de financiamento prevista na Pecking Order Theory (POT).

Para auxiliar na análise de dados serão apresentados gráficos e tabelas sobre o comportamento da alavancagem das empresas e sobre a comparação entre fontes utilizadas no financiamento das empresas.

\subsection{Análise dos Resultados da Regressão dos Fatores x Endividamento (STT)}

Em todos os anos, em primeiro lugar, foram removidas as empresas do ramo financeiro e de as de seguros. Em segundo lugar, as que no ano tiveram patrimônio líquido negativo, conforme explicado no capítulo de metodologia. Em terceiro lugar foram eliminadas empresas que não tinham algum dos dados necessários à pesquisa. Devido a muitos problemas de falta de dados, o número final analisado é menor do que o número total de empresas não financeiras listadas na BM\&FBOVESPA, conforme será mostrado na continuação do trabalho.

A variável dependente nas regressões foi a alavancagem representada por empréstimos e debêntures, de curto e longo prazo, divididos por PL. Na literatura sobre o assunto há 
diferentes interpretações sobre a melhor medida da alavancagem. Medeiros e Daher (2004, p. 189) usaram várias medidas de alavancagem e acharam que a melhor, para a o teste usando a equação original de Rajan e Zingales (1995), foi a da dívida em relação aos ativos totais. Frank \& Goyal (2002) usaram a dívida sobre o capital total. Rajan \& Zingales (1995), para comparar alavancagens de vários países, usaram também várias medidas, como dívidas sobre capital total e sobre ativos totais.

$\mathrm{Na}$ tabela abaixo estão resumidos os principais resultados alcançados nesta primeira parte da pesquisa empírica. O número de empresas mostrado é o total analisado depois de todas as eliminações necessárias já explicadas. Na descrição detalhada dos resultados, após a tabela, o total inicial de empresas e as eliminações serão detalhados.

Tabela 2 - Regressão dos fatores x endividamento (STT).

\begin{tabular}{|c|c|c|c|c|c|c|c|}
\hline \multirow{2}{*}{ Ano } & \multirow{2}{*}{$\begin{array}{c}\mathrm{N}^{\mathrm{o}} \mathrm{de} \\
\text { empresas }\end{array}$} & \multirow{2}{*}{$\begin{array}{c}\mathrm{R} \\
\text { quadrado } \\
\text { ajustado }\end{array}$} & \multirow{2}{*}{$\begin{array}{l}\text { Significância } \\
\text { da regressão }\end{array}$} & \multicolumn{4}{|c|}{ Coeficientes da Regressão Múltipla } \\
\hline & & & & LCR & MBV & LS & $\mathrm{T}$ \\
\hline 2000 & 212 & 0,88 & 0,000 & $\mathbf{0 , 0 1}$ & 1,57 & $-0,60$ & NSign \\
\hline 2001 & 201 & 0,60 & 0,000 & $-5,59$ & $-11,04$ & $-52,41$ & NSign \\
\hline 2002 & 186 & 0,94 & 0,000 & -6.57 & NSign & NSign & NSign \\
\hline 2003 & 187 & 0,76 & 0,000 & NSign & 104,19 & $-24,00$ & NSign \\
\hline 2004 & 195 & 0,44 & 0,000 & NSign & 422,42 & NSign & NSign \\
\hline 2005 & 185 & 0,08 & 0,000 & $-0,27$ & NSign & NSign & NSign \\
\hline 2006 & 196 & 0,85 & 0,000 & $-1,40$ & 73,19 & NSign & 161,14 \\
\hline 2007 & 246 & 0,50 & 0,000 & $-0,97$ & 6,61 & $\mathbf{9 , 3 1}$ & NSign \\
\hline 2008 & 238 & 0,01 & 0,145 & NSign & NSign & NSign & NSign \\
\hline 2009 & 237 & 0,88 & 0,000 & $-8,79$ & 43,41 & 42,57 & 255,51 \\
\hline 2010 & 230 & 0,99 & 0,000 & $-0,63$ & $\mathbf{3 6 9 , 5 7}$ & NSign & NSign \\
\hline
\end{tabular}

Os valores em negrito têm significância ao nível de $1 \%$ os outros a 5\%. Ano 2010 até junho.

No ano 2000, o número inicial de empresas listadas foi de 420 , excluindo as financeiras e seguradoras ficaram 395. Eliminando 49 empresas com PL negativo ficaram 346. Eliminando também empresas sem dados sobre alguma das variáveis a serem regredidas, sobraram 212 empresas para serem analisadas.

A variável que mais contribui para a diminuição do número de empresas em condições de participar da regressão é o MBV, por falta de dados sobre valor de mercado, observação válida também para os anos seguintes. Apesar do número reduzido, o que vai se repetir nos outros anos, trata-se da população de empresas não financeiras de capital aberto que tiveram os dados necessários à pesquisa publicados no ano.

$\mathrm{Na}$ primeira regressão entre as variáveis independentes que são valor de mercado $\mathrm{x}$ contábil (MBV), logaritmo das vendas (LS), lucratividade (LCR) e tangibilidade (T) com a 
variável dependente endividamento (D), o $\mathrm{R}$ quadrado ajustado ficou em 0,88, com significância muito boa ao nível de $1 \%$. Os coeficientes com significância estatística, ao nível de 0,01 , foram a constante com valor de 71,66, o MBV com 1,57, a LCR com 0,01 e o LS com-0,60. A tangibilidade (T) não teve significância, mesmo ao nível de 5\%.

Pode-se então concluir que no ano 2000 o coeficiente relativo à lucratividade (LCR) se comportou de acordo com o previsto pela STT. Os coeficientes dos fatores tamanho da empresa (LS) e oportunidade de crescimento (MBV), com valores negativos e positivos respectivamente, não estão de acordo com a mesma teoria. $\mathrm{O}$ fator tangibilidade ( $\mathrm{T}$ ) ficou fora da regressão por não ter significação estatística, mesmo ao nível de 5\%.

Em 2001, o número inicial de empresas foi de 417. Eliminando as financeiras ficaram 381. Excluindo as 46 empresas com PL negativo, restaram 335 entidades. Eliminando também empresas sem nenhum dado ou sem nenhuma informação sobre a variável dependente, sobraram 201 empresas para serem analisadas.

O R quadrado ajustado de 2001 ficou em 0,60, com boa significância ao nível de $1 \%$. Os coeficientes com significância estatística ao nível de $1 \%$ foram a constante com valor de 1.259,26, a LCR com -5,59 e o LS com -52,41. A MBV ao nível de 5\% ficou com -11,04. A tangibilidade (T) não teve significância, mesmo ao nível de $5 \%$.

Pode-se então concluir que no ano 2001 somente o coeficiente de MBV se comportou de acordo com o previsto pela STT. O coeficiente da lucratividade (LCR) teve sinal contrário ao esperado pela STT e concordante com a POT, podendo significar que as empresas mais lucrativas são menos endividadas.

No ano 2002, de um total de 400 empresas, 365 eram não financeiras. Foram eliminadas 54 empresas com PL negativo restaram 311. Eliminando também empresas sem algum dos dados necessários à regressão, sobraram 186 empresas para serem analisadas. O R quadrado ajustado ficou em 0,94 , estatísticamente significativo ao nível de $1 \%$. O único coeficiente com significância estatística, ao nível de 1\%, foi o da LCR com valor de -6,57.

Então em 2002, novamente, o único coeficientes usado na regressão, a lucratividade (LCR), não se comportou de acordo com o previsto pela STT, tendo sinal negativo, ao contrário ao esperado pela STT.

Em 2003, as empresas listadas na BM\&FBOVESPA, de acordo com o banco de dados economatica ${ }^{\circledR}$, eram 383, sendo 352 as não financeiras. Foram eliminadas 50 empresas com PL negativo ficaram 302. Eliminando também empresas sem nenhum dado ou sem nenhuma informação sobre a variável dependente, sobraram 187 empresas para serem analisadas. O R quadrado ajustado ficou em 0,76 , com boa significância ao nível de $1 \%$. Os únicos 
coeficientes com significância estatística foram o MBV com valor de 104,19, ao nível de 1\%, e o LS com $-24,00$, a $5 \%$.

Então, em 2003, os coeficientes significativos não se comportaram de acordo com o previsto pela STT, tendo apresentado sinais contrários aos esperados.

Em 2004, de um total de 387 empresas, 355 eram não financeiras. Eliminadas 49 empresas com PL negativo, ficaram 306. Eliminando também empresas sem algum dos dados necessários à regressão, sobraram 195 empresas para serem analisadas. O R quadrado ajustado ficou em 0,44 , significante ao nível de $1 \%$. O único coeficiente com significância estatística, também a $1 \%$, foi o MBV com valor de 422,42. Os outros coeficientes não tiveram significância nem a 5\% para participar do modelo.

Então novamente, em 2004, o único coeficientes significativo (do MBV) não se comportou de acordo com o previsto pela STT, tendo apresentado sinal positivo, ao contrário do esperado pela STT.

Em 2005, de 384 empresas listadas 352 eram não financeiras e não seguradoras. Eliminando 50 empresas com PL negativo ficaram 302. Removendo da amostra empresas sem algum dado imprescindível para a regressão, sobraram 185 empresas para serem analisadas. $\mathrm{O}$ $\mathrm{R}$ quadrado ajustado ficou muito baixo, com valor de 0,08 , apesar de continuar com boa significância ao nível de $1 \%$. Só um coeficiente teve significância estatística e foi o da LCR com valor de $-0,27$ ao nível de $1 \%$.

Então, em 2005, apesar do R quadrado muito baixo, praticamente invalidando a regressão, a LCR ficou com sinal negativo, ao contrário do esperado pela STT.

No ano de 2006, o total inicial de empresas listadas foi de 412, sendo 374 as não financeiras. Eliminaram-se 49 empresas com PL negativo restando 325. Excluindo também empresas sem algum dado necessário à regressão, ficaram 196 empresas para serem analisadas. O R quadrado ajustado voltou a ficar bom, com valor de 0,85, e também com boa significância ao nível de $1 \%$. Os coeficientes com significância estatística, os três primeiros ao nível de $1 \%$ e o último a $5 \%$, foram a constante com valor de $-203,13$, o MBV com valor de 73,19, a LCR com -1,40 e T com 161,14.

Portando, em 2006, somente o coeficiente de T (tangibilidade) se comportou de acordo com o previsto pela STT, tendo o MBV apresentado sinal positivo e a LCR ficado com sinal negativo.

Para o ano de 2007, de um total de 421 empresas 380 eram as não financeiras. Excluindo 49 empresas com PL negativo ficaram 331. Eliminando também empresas com dados faltantes, restaram 246 empresas para serem analisadas. De todos os anos estudados, 
este foi o maior número de empresas com as características previstas pela pesquisa disponível no mesmo período.

$\mathrm{Na}$ regressão de 2007, o R-quadrado ajustado ficou com valor de 0,50, com boa significância ao nível de $1 \%$. Os coeficientes com significância estatística, todos ao nível de $1 \%$, foram o LS no valor de 9,31 e o MBV com valor de 6,61 e a LCR com -0,97.

No ano de 2007, então, o coeficiente de LS se comportou como previsto STT e na POT, mas novamente o MBV e a LCR apresentaram sinais em desacordo com a STT.

Em 2008, o total inicial foi de 406 empresas e havia 367 não financeiras. Eliminando 51 com PL negativo ficaram 316. Excluindo aquelas sem algum dado necessário para a regressão, restaram 238 empresas para serem analisadas. O R quadrado ajustado ficou baixíssimo com valor de 0,01 , sem significância estatística estatística ao nível de 5\%. Portanto, em 2008, não houve a regressão esperada.

Para o ano de 2009, de 393 empresas listadas 360 eram não financeiras não seguradoras. Excluindo também aquelas com PL negativo ficaram 291. Eliminando também empresas sem algum dado necessário, restaram 237 empresas para serem analisadas.

O R quadrado ajustado de 2009 ficou bom, com valor de 0,88, com boa significância ao nível de $1 \%$. Os coeficientes com significância estatística de $1 \%$ foram os do MBV com valor de 43,41 e da LCR no valor de -8,79. Com significância a 5\%, ficaram os do LS com 42,57. e de T com 255,51. Também a constante teve significância ao nível de $1 \%$ ficando em $-995,96$.

Em 2009, mais uma vez, os coeficientes de MBV e LCR apresentaram valores com sinais contrários aos esperados pela STT, porque, de acordo com a teoria, a lucratividade deveria apresentar coeficiente positivo e a capacidade de crescimento (MBV) sinal negativo. Os coeficientes de LS e de T tiveram o sinal esperado por ambas as teorias estudadas.

Até junho de 2010, partindo de um número inicial de 383 empresas, 348 eram não financeiras. Retirando da amostra as empresas com PL negativo, ficaram 294. Excluindo as sem algum dado necessário, restaram 230 empresas para serem analisadas. O R quadrado ajustado ficou bom, com valor de 0,99 , com boa significância ao nível de $1 \%$. Os coeficientes com significância estatística a 1\% foram o MBV com valor de 43,41 e o LCR com 369,57. Também a constante teve significância ao nível de 1\% ficando em -802,95.

Então, em 2010, os coeficientes de MBV e da LCR apresentaram valores com sinal contrário ao esperado pela STT. 


\subsubsection{Estatística teste e pressupostos da regressão da STT}

Os Rs quadrados ajustados das regressões ficaram muito baixos em 2005 e 2008, com valores de 0,08 e 0,01 respectivamente. De acordo com o teste F-ANOVA em 2005 o R quadrado ficou acima de zero com significância de 0,000. Já em 2008 o mesmo teste indicou que não houve a regressão esperada, já que a significância ficou em 0,145. Em 2001, 2004 e 2007, como pode ser observado na tabela 2, os Rs quadrados ficaram razoáveis, com valores de 0,60, 0,44 e 0,50 respectivamente, também com significância de 0,000. Em todos os outros anos os R quadrados ficaram bons, com valores entre 0,76 e 0,99, também estatisticamente significantes ao nível de um por cento.

Os coeficientes que participaram das regressões, como também mostrado na tabela 2 , tiveram boa significância estatística. De acordo com o teste t de Student, os coeficientes de MBV e LS em 2001, de LS em 2003, de T em 2006, de LS e de T em 2009 tiveram significância estatística ao nível de 5\%. Todos os outros valores encontrados, de acordo com o mesmo teste, tiveram significância ao nível de $1 \%$.

Em todos os anos estudados os pressupostos das correlações relativos a multicolinearidade, de acordo com o teste VIF (variance inflation factor), ficaram entre $1 \mathrm{e}$ 10, valores que podem ser considerados bons de acordo com Corrar et al. (2007).

A ausência de autocorrelação serial, de acordo com o teste Durbin-Watson, ficou para todos os anos estudados, entre 1,52 e 2,05, dentro do esperado, porque deve estar próximo de 2, também de acordo com Corrar et al. (2007).

A normalidade dos resíduos não foi boa em nenhum dos anos estudados. Porque usando o teste Kolmogorov-Smirnov ela devia ficar com significância acima de 0,01, mas em todos os anos a significância ficou em 0,000. O que indica falta de normalidade na distribuição dos resíduos de acordo com os mesmos autores citados no parágrafo anterior.

A homocedasticidade dos resíduos, conforme o teste Pesarán-Pesarán, ficou ruim nos anos de 2000, 2002, 2004, 2005, 2008 e 2009, porque, nesses anos, a significância foi de 0,000. Nos outros anos, ela ficou boa de acordo com Corrar et al. (2007), porque as significâncias ficaram acima de 0,1000.

Como os resultados serão analisados somente em relação ao pequeno universo de empresas que obedecem aos requisitos da pesquisa, não extrapolando para outras amostras, o R-quadrado e os coeficientes significativos podem ser aceitos, mesmo com as restrições apontadas. 


\subsubsection{Resumo das conclusões sobre a STT}

Resumindo essa primeira parte da pesquisa empírica, os resultados, com todas as restrições mostradas, mostram que há indícios que apontam para o comportamento previsto na POT. Sempre se tomando o cuidado de repetir que o resultado não pode ser extrapolado para outras populações ou épocas, principalmente devido ao problema da distribuição da população estudada não se aproximar da curva normal. Por outro lado o $\mathrm{R}$ quadrado teve valores muito bons em seis dos onze anos estudados, sempre com boa significância ao nível de $1 \%$.

Os indícios que apontam para a POT, são os sinais encontrados para os coeficientes da regressão, que, no caso da STT, são positivos para a tangibilidade (T), negativos para a oportunidade de crescimento (MBV), positivos para tamanho (LS) e positivos para a lucratividade (LCR). Esses sinais esperados para os coeficientes, no caso da STT, são os mesmos do trabalho de Frank \& Goyal (2002) e de Medeiros e Daher (2008). No caso da POT a diferença é o sinal do coeficiente da lucratividade (LCR) que deve ser negativo, indicando que empresas mais lucrativas se endividam menos. A tabela abaixo mostra os sinais esperados e encontrados na regressão.

Tabela 3 - Sinais esperados e encontrados para as teorias POT e STT

\begin{tabular}{|c|c|c|c|c|c|c|c|c|}
\hline \multirow{3}{*}{ Anos } & \multicolumn{8}{|c|}{ Encontrados } \\
\hline & \multicolumn{2}{|c|}{ MBV } & \multicolumn{2}{|c|}{$\mathrm{LS}$} & \multicolumn{2}{|c|}{$\mathrm{T}$} & \multicolumn{2}{|c|}{ LCR } \\
\hline & $\begin{array}{c}\text { STT } \\
\text { Esperado } \\
\text { Negativo }\end{array}$ & $\begin{array}{c}\text { POT } \\
\text { Esperado } \\
\text { Negativo }\end{array}$ & $\begin{array}{c}\text { STT } \\
\text { Esperado } \\
\text { Positivo }\end{array}$ & $\begin{array}{c}\text { POT } \\
\text { Esperado } \\
\text { Positivo }\end{array}$ & $\begin{array}{c}\text { STT } \\
\text { Esperado } \\
\text { Positivo }\end{array}$ & $\begin{array}{c}\text { POT } \\
\text { Esperado } \\
\text { Positivo }\end{array}$ & $\begin{array}{c}\text { STT } \\
\text { Esperado } \\
\text { Positivo }\end{array}$ & $\begin{array}{c}\text { POT } \\
\text { Esperado } \\
\text { Negativo }\end{array}$ \\
\hline 2000 & \multicolumn{2}{|c|}{ Positivo } & \multicolumn{2}{|c|}{ Negativo } & \multicolumn{2}{|c|}{ Não significativo } & \multicolumn{2}{|c|}{ Positivo } \\
\hline 2001 & \multicolumn{2}{|c|}{ Negativo } & \multicolumn{2}{|c|}{ Negativo } & \multicolumn{2}{|c|}{ Não significativo } & \multicolumn{2}{|c|}{ Negativo } \\
\hline 2002 & \multicolumn{2}{|c|}{ Não Significativo } & \multicolumn{2}{|c|}{ Não significativo } & \multicolumn{2}{|c|}{ Não significativo } & \multicolumn{2}{|c|}{ Negativo } \\
\hline 2003 & \multicolumn{2}{|c|}{ Positivo } & \multicolumn{2}{|c|}{ Negativo } & \multicolumn{2}{|c|}{ Não significativo } & \multicolumn{2}{|c|}{ Não significativo } \\
\hline 2004 & \multicolumn{2}{|c|}{ Positivo } & \multicolumn{2}{|c|}{ Não significativo } & \multicolumn{2}{|c|}{ Não significativo } & \multicolumn{2}{|c|}{ Não significativo } \\
\hline 2005 & \multicolumn{2}{|c|}{ Não significativo } & \multicolumn{2}{|c|}{ Não significativo } & \multicolumn{2}{|c|}{ Não significativo } & \multicolumn{2}{|c|}{ Negativo } \\
\hline 2006 & \multicolumn{2}{|c|}{ Positivo } & \multicolumn{2}{|c|}{ Não significativo } & \multicolumn{2}{|c|}{ Positivo } & \multicolumn{2}{|c|}{ Negativo } \\
\hline 2007 & \multicolumn{2}{|c|}{ Positivo } & \multicolumn{2}{|c|}{ Positivo } & \multicolumn{2}{|c|}{ Não significativo } & \multicolumn{2}{|c|}{ Negativo } \\
\hline 2008 & Não sig & ficativo & Não sig & ficativo & Não sig & ficativo & Não sį & ificativo \\
\hline 2009 & Pos & ivo & $\mathrm{Po}$ & ivo & $\mathrm{Po}$ & ivo & $\mathrm{Ne}$ & tivo \\
\hline 2010 & Pos & ivo & Não sig & ficativo & Não sig & ficativo & $\mathrm{Ne}$ & tivo \\
\hline
\end{tabular}

Ano de 2010, somente até junho.

Em sete anos, dos dez estudados, a lucratividade (LCR) se relacionou negativamente com o total de empréstimos das empresas, favorecendo a POT, e só no ano 2000 teve o sinal previsto pela STT. Já o fator capacidade de crescimento, representado por valor de 
mercado/valor contábil (MBV), também contrariando a teoria STT, teve o sinal positivo em sete dos onze períodos estudados. Esse último fato também não é esperado na maioria das interpretações da POT.

Outra constatação interessante é que o fator tangibilidade esteve ausente de nove das onze regressões nos anos analisados. O fator tamanho (LS) participou de cinco regressões, tendo tido o sinal negativo em três delas, ao contrário do esperado pela STT e pela POT. Mas teve o sinal positivo em duas outras, em 2007 e 2009.

O fator decisivo, que aponta para o comportamento previsto pela POT, principalmente em sua versão mais simples, foi a rentabilidade. De acordo com as regressões obtidas nos dez anos e meio (2000 até junho de 2010) da pesquisa, as empresas mais rentáveis são menos endividadas, fato só contrariado pela regressão do ano 2000. Portanto, esta primeira parte da pesquisa empírica mostrou que há indícios da preferência pela POT no comportamento financeiro das empresas brasileiras estudadas.

Uma observação importante na análise dos resultados é que de acordo com artigo publicado por Strebulaev (2007), uma melhor análise da relação entre alavancagem e lucratividade tem que levar em conta fatores que mudam após a tomada de decisões de financiamento. Porque nos momentos em que a empresa busca financiamento externo, geralmente, a alavancagem se relaciona positivamente com a lucratividade, relação que se inverte quando a empresa não precisa recorrer a novos financiamentos, sempre de acordo com o mesmo autor.

Como os testes aplicados nesta dissertação não levam em conta os momentos da tomada de decisão, sempre usando números do fechamento do balanço ou do meio do ano, no caso de 2010, não há como usá-los para analisar a afirmação de Strebulaev (2007).

Os resultados desta primeira parte concordam, em parte, com os de Medeiros e Daher (2008) para o Brasil, principalmente no fator lucratividade (LCR) em que eles também encontraram o sinal negativo. Os autores encontraram resultados diferentes para MBV que no caso deles foi não significativo. Para o tamanho (LS) o resultado nesta pesquisa teve anos positivos e negativos, não sendo possível a comparação. Na tangibilidade (T), o resultados não foram iguais, sendo que nesta pesquisa esse fator quase não teve significância. Mas não se pode fazer uma comparação rigorosa porque, diferentemente deste trabalho, aqueles autores usaram dados em painel abrangendo vários anos. 
No caso de Frank \& Goyal (2002), os resultados desta dissertação concordam em parte, principalmente no item lucratividade (LCR) em que os autores também encontraram sinal negativo. Esta pesquisa também está de acordo, em parte, com Rajan \& Zingales (1995) que encontraram relacionamento negativo entre lucratividade (LCR) e endividamento.

Para finalizar essa primeira parte da análise empírica, são exibidos abaixo uma tabela e alguns gráficos do período estudado, para ajudar na verificação de como se comportou o nível de endividamento (alavancagem) em relação ao capital próprio ao capital total (PL somado às dívidas totais) das empresas estudadas.

A tabela apresenta o nível de endividamento tanto em relação ao capital próprio quanto ao capital total das empresas. O primeiro gráfico mostra o nível de alavancagem financeira em relação ao Patrimônio Líquido (PL). O segundo gráfico mostra o mesmo endividamento comparado ao capital total, isto é, ao capital próprio e de terceiros somados.

Além do valor agregado de todas as empresas que participaram da pesquisa, foram escolhidas, para exemplificar, mas algumas grandes corporações de capital aberto que mantiveram, no período estudado, características próprias aproximadamente estáveis, como tamanho, setor industrial etc.

Tabela 4: Endividamento de Empresas Brasileiras de Capital Aberto (\%)

\begin{tabular}{|c|c|c|c|c|c|c|c|c|}
\hline \multirow{2}{*}{ Anos } & \multicolumn{2}{|c}{$\begin{array}{c}\text { Todas as } \\
\text { Empresas }\end{array}$} & \multicolumn{2}{|c}{ Petrobrás } & \multicolumn{2}{c|}{ Vale } & \multicolumn{2}{c|}{ Ambev } \\
\cline { 2 - 9 } & A & B & A & B & A & B & A & B \\
\hline 2000 & 61,61 & 38,12 & 69,26 & 40,92 & 74,80 & 42,79 & 71,27 & 41,61 \\
\hline 2001 & 74,24 & 42,61 & 65,02 & 39,40 & 81,36 & 44,86 & 135,85 & 57,60 \\
\hline 2002 & 97,91 & 49,47 & 89,74 & 47,30 & 114,03 & 53,28 & 108,65 & 52,07 \\
\hline 2003 & 86,92 & 46,50 & 85,58 & 46,12 & 91,77 & 47,85 & 138,81 & 58,13 \\
\hline 2004 & 72,26 & 41,95 & 59,77 & 37,41 & 66,52 & 39,95 & 45,96 & 31,49 \\
\hline 2005 & 64,00 & 39,02 & 57,04 & 36,32 & 52,07 & 34,24 & 36,26 & 26,61 \\
\hline 2006 & 67,78 & 40,40 & 45,18 & 31,12 & 127,02 & 55,95 & 49,65 & 33,18 \\
\hline 2007 & 57,50 & 36,51 & 33,65 & 25,18 & 62,79 & 38,57 & 56,56 & 36,13 \\
\hline 2008 & 74,84 & 42,80 & 45,77 & 31,40 & 47,12 & 32,03 & 63,81 & 38,95 \\
\hline 2009 & 70,09 & 41,21 & 62,45 & 38,44 & 43,95 & 30,53 & 32,98 & 24,80 \\
\hline 2010 & 68,84 & 40,77 & 66,55 & 39,96 & 41,78 & 29,47 & 28,45 & 22,15 \\
\hline
\end{tabular}

Observações: A - (Dividas + Debêntures) / Patrimônio Líquido; B - (Dividas + Debêntures) / (Dívidas + Debêntures + PL) Dívidas e Debêntures de Curto e Longo Prazo. Dados colhidos no Banco de Dados Economática® em 30/10/2010. 
Pela própria tabela pode-se notar a grande variação nos percentuais de endividamento durante o período estudado. Como era de se esperar, os índices em relação ao PL (capital próprio) são sempre os maiores e que apresentam maior variação. Em relação ao capital total (próprio mais de terceiros) os índices e variações são menores mas, mesmo assim, não mantêm nenhuma estabilidade, mesmo no conjunto de empresas. A seguir é mostrado um gráfico que mostra a alavancagem em relação ao PL das empresas em pauta.

Gráfico 1 - Endividamento das empresas estudadas

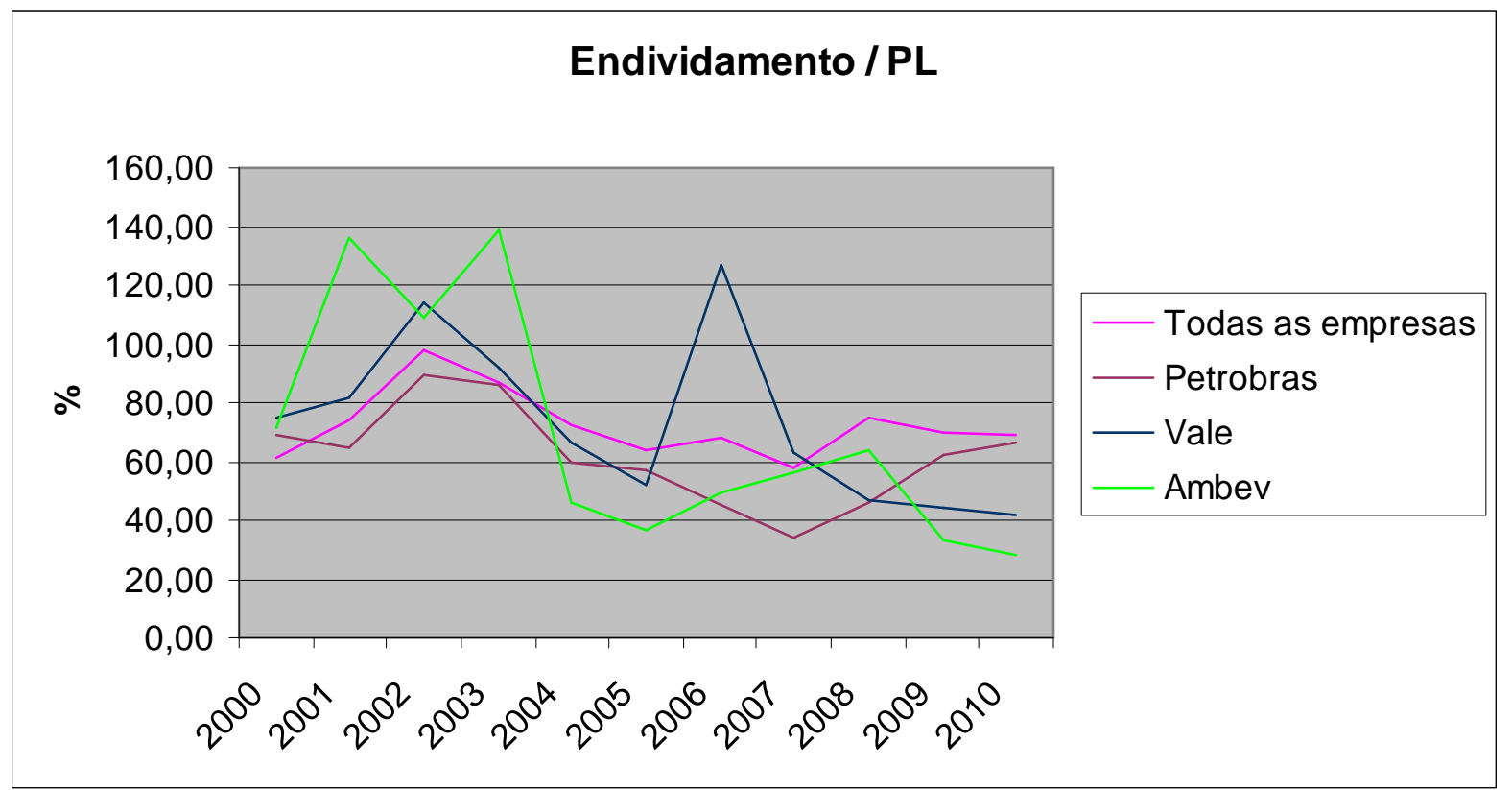

Algumas observações podem ser feitas a respeito da interpretação do gráfico. Em primeiro lugar, o que a teoria STT procura determinar não é uma porcentagem estável entre o capital de terceiros e o próprio, pois o fator estático da teoria é o tradeoff. Então, a cada novo período estudado, dependendo da variação dos fatores que influenciam o nível de endividamento, esse nível seria diferente. Os gráficos podem estar mostrando essa suposta necessidade de mudança para manter os custos e benefícios do endividamento equilibrados.

A resposta a esse primeiro questionamento é que seria necessário haver uma teoria bem mais desenvolvida na área de estrutura de capital, para que se pudesse saber o peso exato e a melhor medida de cada um dos fatores e quais exatamente são eles. Na situação atual das teorias, reconhecida por muitos estudiosos como confusa, ainda não dá, até onde se sabe, para esse tipo de refinamento. 
Sobre a situação atual da teoria pode-se citar, por exemplo, Famá e Grava (2000) que escrevem: “... pois claro está que o tema estrutura de capital está longe de conclusivo”. Conforme Famá et al. (2001) "Embora tenham-se iniciado em meados do século XX, as controvérsias científicas sobre o problema da estrutura de capital das empresas encontram-se longe de seu término." Também Myers (2001) escreve: "There is no universal theory of the debt-equity choice, and no reason to expect one."

Há também, conforme pode ser observado nos gráficos, muitas vezes, uma variação grande de um período para o outro para ser explicada só pelas mudanças nos fatores.

Uma segunda questão que pode ser levantada e que já foi discutida na metodologia, é a maneira de se medir a alavancagem. Entre outras formas, uma melhor talvez fosse aquela que levasse em conta o valor de mercado, tanto da empresa como o das dívidas. Tentou-se, nesta dissertação, medir-se de duas formas a alavancagem. A principal foi a do capital de terceiros dividido pelo Patrimônio Líquido das empresas. A outra foi a que teve como denominador o capital total (PL + capital de terceiro).

Os resultados das regressões, que estão na tabela 2 e foram discutidos neste capitulo, são os das alavancagens medidas da primeira maneira (empréstimos/PL). Na tabela 3 e nos gráficos é mostrada também a alavancagem em relação ao capital total das empresas (PL + capital de terceiros). Abaixo é mostrado outro gráfico em que a alavancagem financeira é relacionada com o capital total das empresas.

Gráfico 2 - Dívidas + Debêntures / Capital Total

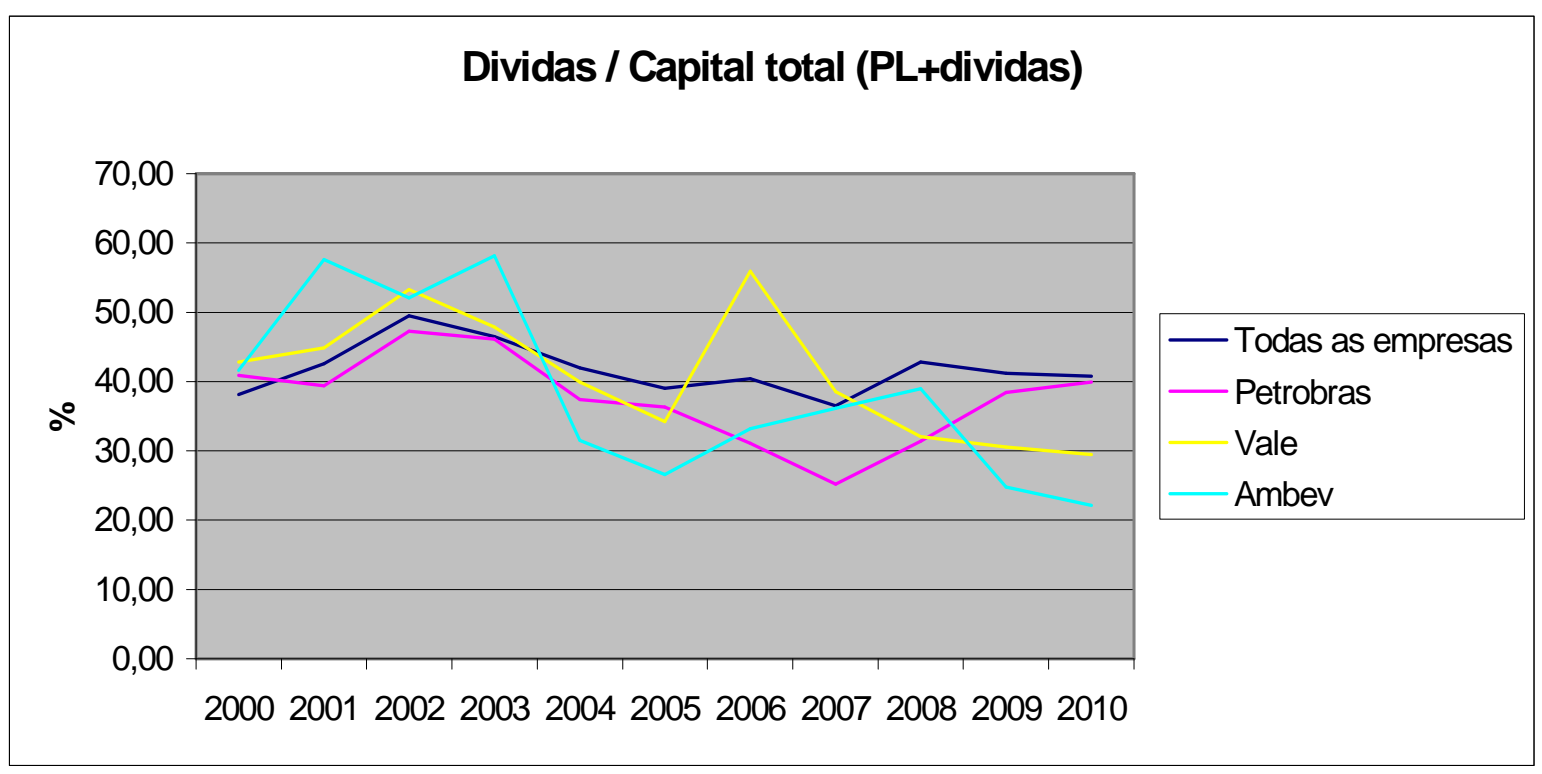




\subsection{Análise dos Resultados da Regressão Déficit x Dívida (POT)}

Essa segunda parte do trabalho empírico, conforme já explicado, é principalmente voltada para o comportamento das empresas quando precisam buscar financiamento externo, após usar recursos internos para seus investimentos e custeios. Nesses casos, de acordo com a teoria Pecking Order semiforte, elas quase sempre prefeririam empréstimos e raras vezes recorreriam a emissões de ações. Caso esse comportamento seja o correto, o coeficiente do termo Def (déficit total da empresa), conforme equação mostrada na metodologia, sempre se aproximará da unidade. A constante "a" da equação tenderá a zero ou será significativamente insignificante.

Note-se, conforme também explicado na metodologia, que os R quadrado obtidos são elevados. O motivo é que nossa pesquisa procurou verificar o déficit total, a ser coberto somente com novos empréstimos e ações, já tendo esgotado todos as outras fontes. Dessa forma, se ocorresse que todas as firmas estudadas não emitissem ou recomprassem ações em determinado ano o R quadrado, no período, seria igual a um.

Diferentemente da primeira parte da pesquisa empírica, em que os valores estudados eram os totais do balanço, nesta parte a pesquisa é feita com os fluxos, não só de caixa mas também de empréstimos e compra e venda de ações. Observe-se que o termo Def se refere não só a déficits mais também a superávits de fundos. O termo E (empréstimos) também pode ser positivo ou negativo, significando a entrada de novos empréstimos ou o pagamento de antigos débitos.

Outro problema é quanto ao número de empresas adequadas ao objetivo deste trabalho. Em todos os anos analisados o número original de empresas listadas na BM\&FBOVESPA, não financeiras, é superior a trezentos . Mas eliminando as que não têm os dados necessários disponíveis a quantidade de empresas diminui. Portanto, são mostradas anualmente, na tabela abaixo, quantas foram efetivamente estudadas.

Foi necessário, conforme explicado na metodologia, descartar os dados das empresas que abriram o capital em cada ano analisado, voltando essas empresas a participar normalmente nos outros anos. Para resolver esse problema, cotejou-se os dados de novas empresas divulgado pela BM\&FBOVESPA com os obtidos no banco de dados economática ${ }^{\circledR}$, retirando-se do rol das firmas estudadas aquelas que tinham integralização de capital pela primeira vez . 
A retirada das empresas entrantes nos anos da primeira integralização de capital foi necessária porque nesses casos não houve preferência pela emissão de ações, conforme tenta provar a teoria testada, e sim a necessidade de emiti-las. Somente foram retirados esses dados quando houve certeza de que a emissão de ações era consequiência da abertura de capital. Casos em que as firmas integralizam seu capital em duas ou mais vezes, só foi considerada para exclusão a primeira vez.

A tabela abaixo resume as conclusões desta segunda parte da pesquisa empírica, mostrando ano a ano os principais resultados alcançados. O número de empresas são as que ficaram após as eliminações explicadas anteriormente. Na descrição dos resultados após a tabela estão detalhados os totais iniciais e as eliminações efetuadas.

Tabela 5 - Regressão Def X Dívidas (POT)

\begin{tabular}{|c|c|c|c|c|c|c|c|}
\hline & \multirow{2}{*}{$\begin{array}{l}\text { Número de } \\
\text { Empresas }\end{array}$} & \multirow{2}{*}{$\begin{array}{l}\mathrm{R} \text { quadrado } \\
\text { ajustado }\end{array}$} & \multirow{2}{*}{$\begin{array}{c}\text { Significância } \\
\text { da } \\
\text { Regressão }\end{array}$} & \multicolumn{4}{|c|}{ Coeficientes da Regressão } \\
\hline & & & & Constante & Signif. & DEF & Signif. \\
\hline 2000 & 324 & $\mathbf{0 , 8 8}$ & 0,000 & -15.987 & 0,009 & $\mathbf{0 , 8 4}$ & 0,000 \\
\hline 2001 & 321 & 0,92 & 0,000 & NSign & 0,232 & $\mathbf{0 , 9 2}$ & 0,000 \\
\hline 2002 & 314 & $\mathbf{0 , 8 3}$ & 0,000 & NSign & 0,374 & $\mathbf{0 , 8 0}$ & 0,000 \\
\hline 2003 & 314 & 0,98 & 0,000 & NSign & 0,078 & 0,95 & 0,000 \\
\hline 2004 & 338 & 0,92 & 0,000 & NSign & 0,331 & 0,86 & 0,000 \\
\hline 2005 & 323 & $\mathbf{0 , 7 0}$ & 0,000 & NSign & 0,307 & $\mathbf{0 , 6 5}$ & 0,000 \\
\hline 2006 & 321 & 0,98 & 0,000 & -72.709 & 0,002 & $\mathbf{0 , 9 7}$ & 0,000 \\
\hline 2007 & 313 & 0,99 & 0,000 & NSign & 0,755 & $\mathbf{0 , 8 2}$ & 0,000 \\
\hline 2008 & 331 & 0,56 & 0,000 & NSign & 0,127 & 0,50 & 0,000 \\
\hline 2009 & 326 & 0,95 & 0,000 & -90.470 & 0,011 & 0,95 & 0,000 \\
\hline 2010 & 282 & $\mathbf{0 , 8 7}$ & 0,000 & -39.025 & 0,033 & 0,91 & 0,000 \\
\hline
\end{tabular}

Os valores em negrito têm significância ao nível de 1\%, os outros a 5\%. 2010 até junho.

Em 2000, de 420 empresas listadas 385 eram não financeiras. Nesse primeiro período não foi excluída nenhuma por abertura de capital. Eliminando as com dados faltantes para a regressão, ficaram 324 empresas para análise. O R quadrado ajustado da regressão foi de 0,88 . A significância também foi boa ao nível de $1 \%$. O coeficiente de DEF foi de 0,84 , também estatisticamente significante ao nível de 1\%. A constante da regressão foi de -15.987 , significante ao nível de $1 \%$. Portanto, os resultados de 2000 são favoráveis à POT.

No ano de 2001, haviam 417 empresas listadas na BM\&FBOVESPA, de acordo com o banco de dados economática ${ }^{\circledR}$, destas 381 eram não financeiras, eliminando-se 4 que integralizaram o capital pela primeira vez, ficaram 377. Retirando da amostra aquelas sem dados suficientes para a regressão, restaram 321 empresas para análise. O R quadrado ajustado da regressão foi de 0,92 , com boa significância ao nível de $1 \%$. O coeficiente de DEF foi de 0,92 , também estatisticamente significante ao nível de $1 \%$. A constante da regressão 
não teve qualquer significância. Naquele ano os resultados também indicam um interpretação favorável à POT.

Para o ano de 2002, das 400 empresas listadas 365 eram não financeiras. Eliminando 3 que abriram o capital, ficaram 362. Destas 314 tiveram dados suficientes para a regressão e foram analisadas. O R quadrado ajustado da regressão foi de 0,83 . A significância também foi muito boa ao nível de 1\%. O coeficiente de DEF foi de 0,80, também estatisticamente significante ao nível de $1 \%$. A constante da regressão não teve qualquer significância. Esses resultados favorecem claramente a POT.

Em 2003, de 383 empresas listadas 352 eram não financeiras. Eliminando 2 que integralizaram o capital pela primeira vez, restaram 350 empresas. Excluindo as que não tinham algum dado para a regressão, ficaram 314 empresas para análise. O R quadrado ajustado da regressão foi de 0,98 . A significância também foi muito boa ao nível de $1 \%$. $\mathrm{O}$ coeficiente de DEF foi de 0,95 , também estatisticamente significante ao nível de $1 \%$. A constante da regressão não teve qualquer significância. Esses resultados indicam como correta a hipótese favorável a POT.

No ano de 2004, haviam 387 empresas listadas e 355 não financeiras. Excluindo 3 que abriram o capital, ficaram 352. Eliminando as que não tinham algum dado para a regressão restaram 338 para análise. O R quadrado ajustado da regressão foi de 0,92. A significância também foi boa ao nível de $1 \%$. O coeficiente de DEF foi de 0,86, também estatisticamente significante ao nível de 1\%. A constante da regressão não teve significância. Esses resultados são, novamente, favoráveis a POT.

Em 2005, as empresas listadas eram 384 e as não financeiras 352. Foram excluídas 7 que abriram o capital e integralizaram no ano. Das 345 restantes eliminou-se mais 22 sem dados suficientes para a regressão, restando 323 empresas a serem analisadas. O R quadrado ajustado da regressão foi de 0,70 , significante estatísticamente ao nível de $1 \%$. O coeficiente de DEF foi de 0,65, também estatisticamente significante ao nível de $1 \%$. A constante da regressão não teve significância. Esses resultados de 2005 favorecem a POT, embora não de maneira conclusiva.

Para o ano de 2006, eram 412 as empresas listadas e dessas 374 não financeiras. Excluídas 20 que abriram o capital e integralizaram no ano, ficaram 354. Eliminadas as sem algum dado para a regressão, sobraram 321 empresas para análise.O R quadrado ajustado da regressão ficou em 0,98 , com boa significância ao nível de $1 \%$. O coeficiente de DEF foi de 
0,97, com boa significância ao nível de $1 \%$. A constante da regressão ficou com valor de 72.709, significante ao nível de 1\%. Esses resultados também são favoráveis a POT.

Em 2007, o total de empresas era de 421 com 380 não financeiras. Nesse ano 43 abriram o capital e integralizaram sendo eliminadas da amostra, restando 337. Dessas restaram 313 com todos os dados necessários para serem analisadas. O R quadrado ajustado da regressão ficou em 0,99, com boa significância a 1\%. O coeficiente de DEF foi de 0,82, também estatisticamente significante ao nível de $1 \%$. A constante da regressão não teve significância. Mais uma vez os resultados favoreceram a interpretação da POT.

A partir do ano 2008, todas as regressões desta segunda parte da pesquisa usarão os dados obtidos através dos Fluxos de Caixa e não mais os das Demonstrações de Origens e Aplicação de Recursos (DOAR), como nos anos anteriores. É que a partir desse ano, em consonância com as normas de outros países, as empresas de capital abertas brasileiras passaram a publicar, obrigatoriamente, esse novo demonstrativo.

No ano de 2008, das 406 empresas listadas 367 eram não financeiras. Eliminadas 6 que integralizaram pela primeira vez o capital, ficaram 361 empresas para análise. O R quadrado ajustado da regressão ficou em 0,56. A significância foi boa ao nível de $1 \%$. $\mathrm{O}$ coeficiente de DEF foi de 0,50 , significante ao nível de $1 \%$. A constante da regressão não teve significância.

Observe-se que nesse ano, pela primeira vez, tanto o $\mathrm{R}$ quadrado como o coeficiente da variável independente ficaram com valores abaixo do esperado. Portanto, em 2008, os valores do $\mathrm{R}$ quadrado e do coeficiente de DEF, embora estatisticamente significativos, não favorecem uma interpretação esperada pela POT.

Para o ano de 2009, de 393 empresas listadas haviam 360 não financeiras e não seguradoras. Excluiu-se 4 que abriram o capital. Das 356 somente 326 empresas tiveram dados suficientes para a regressão. O R quadrado ajustado da regressão ficou em 0,95. A significância também foi boa ao nível de 1\%. O coeficiente de DEF também foi de 0,95, estatisticamente significante ao nível de $1 \%$. A constante da regressão ficou em -90.470 , com significância ao nível de 5\%. Esses resultados favorecem, mais uma vez, a POT.

Em junho de 2010 havia 383 empresas listadas e 348 eram não financeiras. Eliminando-se 4 que integralizaram capital pela primeira vez, ficaram 344. Dessas somente 282 empresas tiveram os dados necessários para a regressão. Nesse último período analisado o R quadrado foi de 0,87 , significante a $1 \%$. O coeficiente de DEF ficou em 0,91, também 
com significância estatística ao nível de $1 \%$. A constante teve valor de -39.025 , com significância ao nível de 5\%. Esses resultados também são favoráveis a interpretação da POT.

\subsubsection{Estatística teste e pressupostos da regressão da POT}

Em nove dos onze períodos analisados os Rs quadrados ajustados das regressões ficaram muito bons, todos acima de 0,83 tendo atingido valores acima de 0,92 em cinco anos. O teste F-ANOVA validou todos os Rs quadrados, com significância estatística ao nível de $1 \%$, inclusive os de 2005 e 2008, que ficaram abaixo do esperado para a validação da POT.

Os coeficientes de Def, validados pelo teste t de Student, todos ao nível de 1\%, tiveram valores muito bons para a validação da teoria POT, exceto nos anos de 2005 e 2008. em que tiveram valores de 0,70 e 0,56 respectivamente. As constantes só tiveram significância em quatro dos períodos analisados, conforme mostrado na tabela 5.

Em todos os anos estudados os pressupostos das correlações relativos a multicolinearidade, de acordo com o teste VIF (variance inflation factor), ficaram entre $1 \mathrm{e}$ 10, valores que podem ser considerados bons de acordo com Corrar et al. (2007).

A ausência de autocorrelação serial, de acordo com o teste Durbin-Watson, ficou boa para todos os anos estudados, com valores entre 1,85 e 2,05. Estando dentro do esperado, porque deve estar próximo de 2, também de acordo com Corrar et al. (2007).

A normalidade dos resíduos não foi boa em nenhum dos anos estudados. Porque usando o teste Kolmogorov-Smirnov ela devia ficar com significância acima de 0,01, mas em todos os anos a significância ficou em 0,000. O que indica falta de normalidade na distribuição dos resíduos de acordo com Corrar et al. (2007).

A homocedasticidade dos resíduos, conforme o teste Pesarán-Pesarán, foi boa nos anos de 2003, 2006, 2007, 2009 e 2010, porque, nesses anos, a significância ficou acima de 0,05. Nos outros anos, ela ficou ruim também de acordo com Corrar et al. (2007), porque as significâncias ficaram abaixo de 0,01 .

Apesar das restrições apontadas anteriormente, os resultados são válidos dentro da amostra estudada, não servindo como inferência estatística para outras amostras, principalmente pela falta de normalidade na distribuição dos resíduos.

\subsubsection{Resumo das conclusões sobre a POT}


Resumindo esta segunda parte da pesquisa empírica, em nove dos onze períodos estudados os resultados não permitem rejeitar a hipótese de que as empresas estudadas se comportaram financeiramente, nos anos analisados, de acordo com o previsto pela POT. Somente nos anos de 2005 e 2008 as previsões da teoria em estudo não foram comprovadas totalmente, sendo parcialmente em 2005. Nos outros nove períodos os Rs quadrados e os coeficientes da variável independente sempre tiveram valores dentro do esperado.

Portanto, pode-se afirmar que, dentro da amostra analisada e nos anos em pauta, há indícios suficientes para comprovar que o comportamento financeiro das empresas esteve dentro do previsto pela Pecking Order Theory semiforte, comprovando que as empresas pesquisadas sempre preferiram em primeiro lugar usar recursos gerados internamente, em segundo lugar tomar empréstimos e só recorrer a emissão de ações em raras ocasiões.

A seguir são inseridos uma tabela e um gráfico que mostram como as empresas se financiaram no período. Pode-se verificar que as empresas em pauta usaram, no período estudado, muito mais recursos gerados internamente, isto é caixa operacional, do que empréstimos, o que está de acordo com a mesma teoria. E, conforme já mostrado, mais empréstimos do que emissões de ações.

Tabela 6: Uso de Fontes de Financiamento pelas Empresas Estudadas

\begin{tabular}{|c|c|c|c|}
\hline \multirow{2}{*}{} & \multicolumn{3}{|c|}{ Fontes de Financiamento } \\
\cline { 2 - 4 } & Caixa Operacional & Empréstimos e Debêntures & Emissão de Ações \\
\hline 2000 & 93.561 .964 & 25.720 .747 & 11.827 .105 \\
\hline 2001 & 90.310 .530 & 33.923 .975 & 6.992 .004 \\
\hline 2002 & 107.041 .319 & 32.199 .382 & 12.077 .404 \\
\hline 2003 & 123.420 .940 & 52.856 .888 & 8.368 .144 \\
\hline 2004 & 155.336 .319 & 48.788 .527 & 11.882 .599 \\
\hline 2005 & 171.820 .044 & 56.280 .148 & 20.505 .171 \\
\hline 2006 & 194.821 .222 & 104.561 .694 & 27.816 .495 \\
\hline 2007 & 209.677 .605 & 70.344 .493 & 16.968 .318 \\
\hline 2008 & 235.103 .487 & 86.915 .847 & 43.494 .574 \\
\hline
\end{tabular}

Observações: Em milhares de Reais. Excluídas as empresas que abriram capital no ano. Fonte: Economática®. 
Não foi incluído na tabela nem no gráfico o ano de 2010, porque como os valores desse ano só estavam disponíveis até junho, não há utilidade em compará-los com os outros anos. Na tabela já se observa que o uso de fontes geradas internamente sempre foi bem maior que as outras origens. Os empréstimos também superaram as emissões de ações em todos os anos.

Se não fossem excluídas as empresas que emitiram ações em cada ano, haveria algumas alterações pouco significativas na maioria dos anos. Somente em 2007, pela grande entrada de novas empresas na BM\&FBOVESPA, a arrecadação total de capitais ficaria maior do que os empréstimos. Só que, conforme já foi observado, não há sentido em incluir empresas entrantes no mercado neste tipo de estudo. A seguir, o gráfico correspondente ilustra melhor a hierarquia de fontes utilizada pelas empresas.

Gráfico 3 - Fontes de Financiamento Utilizadas Pelas Empresas Estudadas

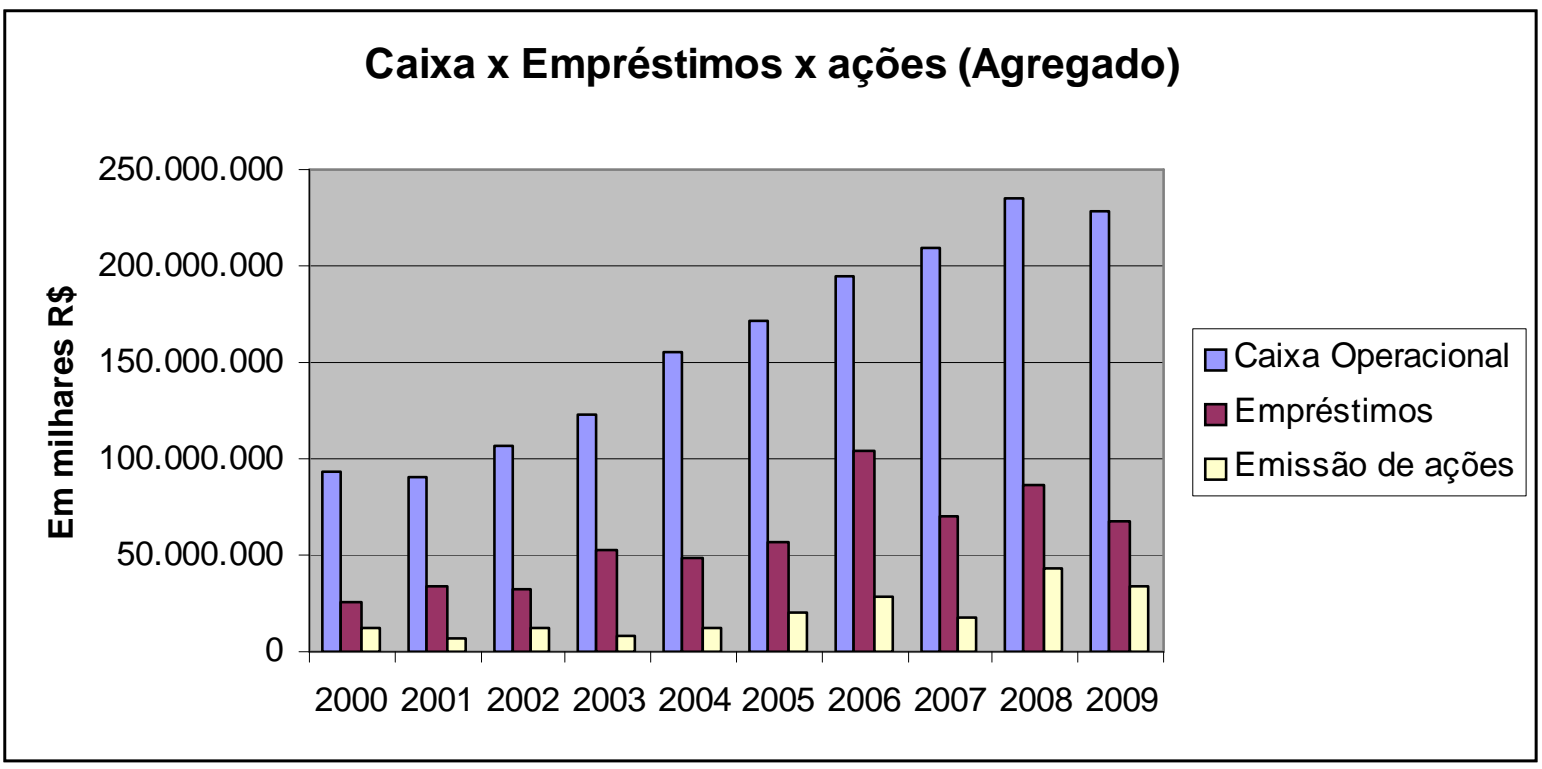

O gráfico mostra, de maneira inequívoca, que as empresas estudadas se utilizaram sempre de muito mais recursos próprios, gerados pelas operações, do que empréstimos. E mais empréstimos que emissão de ações. Mesmo nos anos em que as regressões analisadas anteriormente não existiram ou não tiveram significância, o gráfico demonstra que foi mantida a hierarquia de fontes preconizada pela POT.

\subsection{Tentativa de Interpretação dos Resultados da Pesquisa}

Os resultados alcançados neste trabalho estão de acordo com a teoria elaborada por Myers (1984) e Myers \& Maljluf (1984), sobre a hierarquia de fontes de financiamento 
preferidas pelas empresas. Como apontado anteriormente, apesar das restrições apontadas, a preferência das empresas estudadas. na grande maioria dos anos, foi, em primeiro lugar por uso de recursos internos. Havendo déficit para giro ou investimento, elas recorrem a empréstimos e emitem ações no último caso.

Os motivos que levam a essas preferências não foram analisados por este estudo, sendo que o objetivo único foi verificar empiricamente as previsões da teoria conhecida como Pecking Order Theory (POT) em comparação com a Static Tradeoff Theory (STT). No entanto pode-se, usando estudos já conhecidos e citados neste trabalho, tentar-se uma explicação desses comportamentos financeiros pelas empresas brasileiras.

Em primeiro lugar, há que se considerar a própria teoria de Myers (1984) e Myers \& Maljuf (1984) em que a assimetria de informações entre os dirigentes da empresa e os possíveis compradores de ações desempenha o principal papel. Nesse caso, os investidores subavaliariam as ações emitidas prejudicando a empresa e os acionistas existentes. No caso do Brasil e das empresas estudadas não dá para afirmar se o comportamento das empresas teria esse motivo. Talvez uma pesquisa sobre variação de preços de ações em torno da data de lançamento possa esclarecer melhor esse ponto.

Em segundo lugar, poderíamos aventar a hipótese de que no Brasil, e em países que usam normas, leis e comportamentos mais burocráticos, mais complexos, deve haver e parece que há, muito mais dificuldades para emissão de ações, não só para abertura de capital, mas para o simples lançamento público de novas ações. Esse tipo de problema e os custos envolvidos devem pesar muito na decisão das empresas. Também não há provas empíricas para essa hipótese, mas ela poderia explicar a preferência por empréstimos, ao invés de emissão de ações, das empresas brasileiras de capital aberto

Quanto ao uso de capital próprio com retenção de lucros, a explicação mais óbvia é que esses são os recursos mais baratos, mais fáceis de se obter. Faz parte da própria lógica do capitalismo que as empresas cresçam usando os próprios lucros. Galbraith (1983, p.168), por exemplo, mostra que a maior parte da poupança americana entre os anos de 1950 e 1980 foi realizada com retenção de lucros das empresas. Em 1976, por exemplo, segundo o mesmo autor, as poupanças privadas naquele país somaram 77,8 bilhões de dólares, contra 198,6 bilhões das empresas, principalmente das grandes corporações. Para as empresas brasileiras analisadas vale o mesmo raciocínio. 
Concluindo essa análise, pode ser que alguma ou mesmo uma combinação das causas citadas levem as empresas brasileiras pesquisadas a se comportarem da forma prevista pela POT. Deve haver mesmo causas não abordadas por esse estudo, como o problema das altas taxas de juros no Brasil, mesmo com a ressalva de que as empresas estudadas, em geral, têm facilidade de acesso a créditos externos. Outros motivos poderiam combinar partes das teorias de agência e de falência nessa explicação. De toda forma, outras pesquisas são necessárias para um melhor esclarecimento da questão. 


\section{CONCLUSÃO E SUGESTÕES PARA NOVAS PESQUISAS.}

Esta dissertação estudou o comportamento financeiro de empresas brasileiras de capital aberto relacionadas na BM\&FBOVESPA. Mais especificamente, como as decisões de financiamento dessas empresas se relacionam com suas estruturas de capital. Os problemas analisados foram: se há uma estrutura ideal que maximize o valor da empresa, como preconizado pela Static Tradeoff Theory (STT) ou se as empresas não buscam essa meta, mas se financiam em primeiro lugar com recursos próprios, em segundo com empréstimos e só em raros casos com emissão de ações, conforme previsto pela Pecking Order Theory (POT).

Para atingir esses objetivos foram obtidos dados, do banco de dados Economatica ${ }^{\circledR}$, referentes aos anos 2000 a 2010, de empresas brasileiras de capital aberto com dados publicados na BM\&FBOVESPA. Os dados utilizados foram os dos Balanços Patrimoniais, Demonstrações de Fluxos de Caixas e Demonstrações de Origem e Aplicação de Recursos (DOAR).

As hipóteses analisadas nessa dissertação foram, de maneira resumida: (i) As empresas brasileiras de capital aberto usam a hierarquia de fontes prevista na POT, isto é, em primeiro lugar capital próprio, em segundo lugar empréstimos e, em raros casos, emissões de ações. (ii) Essas empresas têm uma meta de empréstimo em relação ao capital próprio que equilibra custos e benefícios do endividamento, conforme previsto pela STT.

De acordo com os resultados apresentados no capítulo quatro deste trabalho, mesmo com as restrições apontadas, têm-se evidências suficientes para não rejeitar a primeira hipótese, e para não aceitar a segunda, concluindo-se que as empresas brasileiras analisadas nesta dissertação, no período estudado, se comportaram de acordo com o previsto pela Pecking Order Theory. O motivo principal para não se tirar inferências estatísticas, que se aplicariam a um universo maior de empresas, é a não normalidade na distribuição dos dados extraídos da população estudada.

Na primeira parte da pesquisa empírica em que é testada a hipótese relacionada com a STT, em sete períodos, dos onze estudados, a rentabilidade se relacionou negativamente com o total de empréstimos das empresas, e só no ano 2000 teve o sinal previsto pela STT, o que favorece a interpretação sugerida pela POT. Outro fator analisado, que foi a capacidade de crescimento, representado por valor de mercado/valor contábil, também contrariando a teoria, 
teve o sinal positivo em sete dos dez períodos estudados. Esse último fato também não é esperado na maioria das interpretações da POT. Os Rs quadrados obtidos em cinco dos anos estudados foram superiores a 0,80, chegando a 0,99 em 2010.

Outra constatação interessante é que os fatores tangibilidade e tamanho das firmas participaram pouco das regressões. A tangibilidade só participou de duas das regressões. O fator tamanho só participou de cinco regressões, tendo tido o sinal contrário ao esperado pela STT em três delas. Aliás, o sinal negativo obtido também não é previsto pela POT. Observese que o tamanho não se relaciona positivamente com o endividamento em termos relativos, se fosse tomado o valor absoluto das empresas e o das dívidas o resultado poderia ter sido diferente.

O fator decisivo, que aponta para o comportamento previsto pela POT, principalmente em sua versão mais simples, foi a rentabilidade. De acordo com as regressões obtidas nos dez anos da pesquisa, as empresas mais rentáveis são menos endividadas, fato só contrariado pela regressão do ano 2000.

$\mathrm{Na}$ segunda parte da pesquisa empírica, em nove dos onze períodos estudados os resultados também não permitem rejeitar a hipótese de que as empresas estudadas se comportaram financeiramente, nos anos estudados, de acordo com o previsto pela POT. Somente nos anos de 2005 e 2008 as previsões da teoria em estudo não foram totalmente comprovadas. Nos outros nove anos os Rs quadrados sempre tiveram valores superiores a 0,80, sendo que em seis deles ficaram acima de 0,90. Esses valores e os coeficientes da variável independente, sempre com boa significância e com os valores próximos ao previsto pela teoria, corroboram a hipótese da Pecking Order Theory, para as empresas e períodos estudados.

Concluindo, as empresas brasileiras de capital aberto, analisadas nessa dissertação, no período estudado, não buscaram metas ideais de endividamento, tendo sempre preferido usar recursos próprios para se financiarem, buscando empréstimos em segundo lugar e só emitindo ações no último caso, conforme previsto na Pecking Order Theory, na sua forma semiforte.

Novos estudos poderiam procurar aglutinar mais empresas na pesquisa, quem sabe buscando nas bolsas de outros países os números de empresas que têm filiais no Brasil. Talvez com um número maior de firmas os pressupostos das regressões referentes a homoscedasticidade e normalidade fossem mais bem atendidos. 
Outros estudos poderiam verificar novas formas de medir as alavancagens e empréstimos utilizando-se valores de mercados. Nesse caso as mesmas regressões utilizadas nesta pesquisa seriam replicadas, com as mesmas variáveis independentes, utilizando-se as novas variáveis dependentes assim obtidas.

Pode-se também tentar-se utilizar os dados dos anos analisados em painel (panel data) procurando dessa forma verificar de forma geral se o resultado confirma as conclusões desta dissertação e de outros trabalhos como os de Medeiros e Daher (2004) e Silva e Brito (2004), para as empresas brasileiras. 


\section{BIBLIOGRAFIA}

AGRAWAL, Anup; MANDELKEN, Gershon. Managerial incentives and corporate investment and financing decisions. The Journal of Finance. v. 17, n 4, september 1987.

ALTMAN, Edward I. A further empirical investigation of the bankruptcy cost question The Journal of Finance, v. 39, No. 4, 1984, pp. 1067-1089.

ASSAF NETO, Alexandre. Mercado financeiro, 6 Edição, São Paulo : Atlas, 2005.

ASSAF NETO, Alexandre. Finanças corporativas e valor, $3^{a}$ Edição, São Paulo: Atlas, 2008.

BAKER, Malcolm; WURGLER, Jeffrey. Market timing and capital structure. The Journal of Finance, v. 57, No. 1. 2002. pp. 1-32

BAXTER, Nevins D. Leverage, risk of ruin and the cost of capital. The Journal of Finance, v. 22, n. 3 (Sep., 1967), pp. 395-403

BOOTH, Laurence; AIVAZIAN, Varouj; DEMIRGÜÇ-KUNT, Asli; MAKSIMOVIC, Vojislav. Capital structures in developing countries. The Journal of Finance, v. 56, $\mathrm{n}^{\mathrm{o}} 1$, February, 2001.

BRADLEY, Michael; JARREL, Gregg A.; KIM, E. Han. On the existence of an optimal capital structure: theory and evidence. The Journal of Finance, v. 39, n 3, 1984. pp. 857-878.

BROUNEN, Dirk; JONG, Abe de; KOEDIJK, Kees. Capital structure policies in Europe: survey evidence. Journal of Economic Literature. Rotterdan. 2005. pp. 1-34.

CHIRINKO, R. S.; SINGHA, A. R., Testing static tradeoff against pecking order models of capital structure: a critical comment. Journal of Financial Economics 58, 2000. PP. 417-425

CORRAR, Luiz J. et al, Análise Multivariada para os cursos de Administração, Ciências Contábeis e Economia, São Paulo: Editora Atlas 2007.

DE ANGELO, H., MASULIS, R., Optimal capital structure under corporate and personal taxation, Journal of Financial Economics, v. 7, 3-29, 1980.

DURAND, David. The cost of capital, corporation finance, and the theory of investment: comment. The American Economic Review, v. 49, no 4, 1959. pp. 639-635.

FAMA, Eugene F.; FRENCH, Kenneth R. Taxes, Financing Decisions, and Firm Value. The Journal of Finance. v. 53, No. 3. Jun. 1998; pp. 819-843.

FAMA, Eugene F.; FRENCH, Kenneth R. Testing Tradeoff and Pecking Order Predictions About Dividends and Debt. The Center for Research in Security Prices. University of Chicago Graduate School of Business. Working Paper, n. 506. Chicago. December, 2000. pp. $1-36$. 
FAMA, Eugene F.; FRENCH, Kenneth R. Financing decisions: who issues stock? Journal of Financial Economics, v. 76. 2005. pp. 549-582.

FAMÁ, Rubens; MELHER, Stefanos. Estrutura de capital na América Latina: existiria uma correlação com o lucro das empresas? IV Seminário em Administração (SEMEAD). Out. 1999.

FAMÁ, R.; GRAVA, J. W. Teoria da estrutura de capital - As discussões persistem. Caderno de Pesquisas em Administração. São Paulo. 2000. pp. 27-36.

FAMÁ, R.; BARROS, L.; SILVEIRA, A. A estrutura de capital é relevante? Novas evidências a partir de dados Norte-Americanos e Latino-Americanos. Caderno de Pesquisas em Administração, 8(2), São Paulo. 2001. pp. 71-84.

FARRAR, D. E.; SELWYN, L. L. Taxes, corporate financial policy and the return to investors. National Tax Journal v. 20, 444-54. 1967.

FAULKENDER, Michael; PETERSEN, Mitchell A. Does the Source of Capital Affect Capital Structure? The Review of Financial Studies. Published by Oxford University Press on behalf of The Society for Financial Studies. v. 19, n 1, 2006. pp. 45-79.

FAZZARI, Steven; HUBBARD, R. Glenn; PETERSEN, Bruce C. Financing constraints and corporate investment. Working paper n. 2387. National bureau of economic research. Cambridge, september 1987

FISCHER, Edwin O.; HEINKEL, Robert; ZECHNER, Josef. Dynamic capital structure choice: theory and tests. The Journal of Finance. v. 44, n 1, março 1989. pp. 19-40.

FLANNERY, M. J., RANGAN, K. P. Partial adjustment toward target capital structures. Journal of Financial Economics, 2005.

FRANK, Murray Z.; GOYAL, Vidhan K. Testing the pecking order theory of capital structure. Journal of Financial Economics. 2002. pp. 1-39.

FRANK, Murray Z.; GOYAL, Vidhan K. Capital structure decisions:which factors are reliably important? Working paper. University of Minnesota, Minneapolis. 2007. pp. 1-59.

FRANK, Murray Z.; GOYAL, Vidhan K. Trade-off and pecking order theories of debt. Handbook of Corporate Finance: Empirical Corporate Finance. B. E. Eckbo. 2007. pp. 1-82.

GALBRAITH, John Kenneth. O novo estado industrial. 2a Edição. São Paulo: Livraria Pioneira Editora. 1983.

GIL, Antônio Carlos. Pesquisa em economia. 2a Edição. São Paulo: Atlas. 1991.

GRAHAM, John K. Debt and the marginal tax rate. Journal of Financial Economics. 1996. pp. 41-73.

GRAHAM, John R. How big are the tax benefits of debt? The Journal of finance. v. 55, n. 5, out. 2000. PP. 1901-1941. 
GRAHAM, John R. Taxes and corporate finance: a review. Review of Financial Studies. v. 16. Oxford University Press. 2003.

GRAHAM, J.R.; HARVEY, C.R. The theory and practice of corporate finance: evidence from the field. Journal of Financial Economics, v. 60, 2001. pp.187-243.

HARRIS, Milton; RAVIV, Artur. Capital structure and the informational role of debt. The Journal of Finance 45, 321-349, 1990a.

HARRIS, Milton; RAVIV, Artur. The theory of capital structure. The Journal of Finance. v. 46, No. 1, 1991. pp. 297-355.

HENDRIKSEN, E. S. ; BREDA, M. F. V. Teoria da contabilidade, $1^{a}$ Edição. São Paulo : Atlas. 1999.

HENNESSY, C. A.; WHITED, T. A. Debt dynamics. Journal of Finance. v. 60, 2005. pp. $1129-1165$.

HOVAKIMIAN, H.; OPLER, T.; TITMAN, S., The debt-equity choice. Journal of Financial and Quantitative Analysis. Seattle. v. 36. 2001. pp. 1-24.

HOVAKIMIAN, A.; HOVAKIMIAN, G.; TEHRANIAN, H. Determinants of target capital structure: the case of dual debt and equity issuers. Journal of Financial Economics, 71. 2004. pp. 517-540.

IUDÍCIBUS, S. ; MARTINS, E. ; GELBKE, E. Manual de contabilidade das sociedades por ações, $7^{\text {a }}$ Edição, São Paulo : Atlas. 2007.

JENSEN, Michael C.; MECKLING, William. Theory of the firm: managerial behavior, agency costs, and capital structure, Journal of Financial Economics. 1976, v. 3, pp. 305-360.

KALE, Jayant R.; NOE, Thomas H.; RAMIREZ, Gabriel G. The effect of business risk on corporate capital structure: theory and evidence. The Journal of Finance, v. 46, No. 5, 1991, pp. 1693-1715.

KAYHAN, Ayla; TITMAN, Sheridan. Firms' histories and their capital structures, NBER working paper n. 10526. 2004.

LEARY, Mark; ROBERTS, Michael R. Do Firms Rebalance Their Capital Structures? The Journal of Finance. v. 60, n. 6. 2005. pp. 2575-2619.

LELAND, Hayne E. Corporate debt value, bond covenants, and optimal capital structure. Journal of Finance, 1994, v. 49, pp. 1213-1252.

LELAND, Hayne E. Agency costs, risk management, and capital structure. The Journal of Finance. v. 53, No. 4, Papers and Proceedings of the Fifty-Eighth Annual Meeting of the American Finance Association, Chicago, Illinois, 1998. pp. 1213-1243. 
LEMMON, M. L.; ZENDER, J. F. Debt capacity and tests of capital structure theories. University of Utah and University of Colorado. Working Paper. 2002.

LONG, M.S., MALITZ, E.B., Investment patterns and financial leverage. In: Freidman, B. (Ed.), Corporate capital structures in the United States. University of Chicago Press, Chicago, IL. 1985.

MAKSIMOVIC, Vojislav; ZECHNER, Josef. Debt, agency costs, and industry equilibrium. The Journal of Finance, v. 46, n. 5. Dez., 1991 , pp. 1619-1643.

MAYER, Colin; SUSSMAN, Oren. A new test of capital structure. Wadham College Saïd Business School University of Oxford. Working Paper. October, 2004. pp. 01-45.

MEDEIROS, Otávio R.; DAHER, Cecílio E. Testando teorias alternativas sobre a estrutura de capital nas empresas brasileiras. $4^{\circ}$ Congresso USP de Controladoria e Contabilidade. São Paulo. 2004. pp. 177-199.

MILLER, Merton H. Debt and taxes. The Journal of Finance. v. 32, nº 2, 1977. pp. 261-275.

MILLER, Merton H.; ROCK, Kevin. Dividend policy under asymmetric information. Journal of Finance. 1985, v. 40, pp. 1031-1051.

MODIGLIANI, F., MILLER, M. H. The cost of capital, corporate finance and the theory of investment. American Economic Review, v. 48, pp. 201-297. 1958.

MODIGLIANI, F., MILlER, M. H. Corporate income taxes and the cost of capital: a correction. American Economics Review, june 1963.

MYERS, S.C., 1984. Determinants of corporate borrowing, Journal of Financial Economics, v. 5, 1977. pp. 147-176.

MYERS, S.C. The capital structure puzzle. Journal of Finance 39, 575-592. 1984.

MYERS, S. C. Still searching for optimal capital structure. Journal of Applied Corporate Finance. 1993. v. 6, pp. 4-14.

MYERS, S.C., MAJLUF, N. Corporate financing and investment decisions when firms have information investors do not have. Journal of Financial Economics, v.13, pp. 187-221. 1984.

MYERS, Stewart. Capital structure. The Journal of Economic Perspectives. Vol. 15, No. 2. pp. 81-102. 2001.

OPLER Tim C.; TITMAN, Sheridan. Financial distress and corporate performance. The Journal of Finance, v. 49, n. 3, Papers and Proceedings Fifty-Fourth Annual Meeting of the American Finance Association, Boston, Massachusetts, January 3-5, 1994, pp. 1015-1040.

RAJAN, Raghuram G.; ZINGALES, Luigi. What do we know about capital structure? some evidence from internantional data. The Journal of Finance. v. 50, pp. 1421-1460, 1995. 
ROSS, S. A.; WESTERFIELD, R. W. ; JAFFE, J. F. Administraçãa financeira, $2^{a}$ Edição. São Paulo: Atlas. 2002.

SCHWARTZ, E., ARONSON, R., 1967. Some surrogate evidence in support of the concept of optimal financial structure. Journal of Finance, v. 22, pp. 10-18.

SHYAM-SANDER, L.; MYERS, S.C. Testing static tradeoff against pecking order models of capital structure. Journal of Financial Economics, v. 51, pp. 219-244. 1999.

SILVA, Júlio César G.; BRITO, Ricardo D. Testando as previsões de trade-off e pecking order sobre dividendos e dívida para o Brasil. Financelab Working Paper 7. Ibmec. São Paulo. Brasil. 2004.

SOLOMON, Ezra, Leverage and the cost of capital. The Journal of Finance, v. 18, n. 2, 1963, pp. 273-279.

STOHS, Mark Hoven; MAUER, David. The determinants of corporate debt maturity structure. The Journal of Business. Chicago. v. 69, n. 3. 1996. pp. 279-312.

STREBULAEV, I. A. Do tests of capital structure theory mean what they say? The Journal of Finance. Chicago, v. 62, n. 4, pp. 1747-1787. 2007.

TITMAN, Sheridan; TSYPLAKOV, Sergey. A dynamic model of optimal capital structure. McCombs Research Paper Series n. FIN-03-06. McCombs School of Business. The University of Texas at Austin. 2006. pp. 1-61.

TITMAN, Sheridan; WESSELS, Roberto. The determinants of capital structure choice. The Journal of Finance, v. 43, n. 1. (Mar., 1988), pp. 1-19.

WARNER, Jerold B. Bankruptcy costs: some evidence. The Journal of Finance. v. 32, n. 2. 1977. pp. 337-347.

WELCH, Ivo. Capital structure and stock returns. Journal of Political Economy, v. 112, n. 1, The University of Chicago. 2004. pp. 106-131. 